\title{
Rekenregels voor de enterische methaan-emissie op het melkveebedrijf en reductie van de methaan- emissie via mesthandling, het handelings- perspectief van het voerspoor inzichtelijk maken met de Kringloopwijzer
}

L. B. Šebek, I. Mosquera en A. Bannink

Dit onderzoek is uitgevoerd als onderdeel van de publiek-private samenwerking (PPS) "Feed4Foodure", en is medegefinancierd door het Ministerie van Economische Zaken, in het kader van het Beleidsondersteunend Onderzoek (projectnummer BO31.03-005-001). 
Šebek, L.B., Mosquera, J., Bannink, A. 2016. Rekenregels voor de enterische methaanemissie op het melkveebedrijf en reductie van de methaanemissie via mest-handling; het handelingsperspectief van het voerspoor inzichtelijk maken met de Kringloopwijzer. Lelystad, Wageningen UR (University \& Research centre) Livestock Research, Livestock Research Rapport 976.

Dit rapport is gratis te downloaden op http://dx.doi.org/10.18174/391726 of op www. wur. nl/livestockresearch (onder Wageningen Livestock Research publicaties)

\section{(C) 2016 Wageningen Livestock Research}

Postbus 338, 6700 AH Wageningen, T 03174839 53, E info.livestockresearch@wur.nl, www.wur.nl/livestock-research. Wageningen Livestock Research is onderdeel van Wageningen University \& Research.

Wageningen Livestock Research aanvaardt geen aansprakelijkheid voor eventuele schade voortvloeiend uit het gebruik van de resultaten van dit onderzoek of de toepassing van de adviezen.

Alle rechten voorbehouden. Niets uit deze uitgave mag worden vermenigvuldigd en/of openbaar gemaakt worden door middel van druk, fotokopie, microfilm of op welke wijze dan ook zonder voorafgaande toestemming van de uitgever of auteur.

De certificering volgens ISO 9001 door DNV onderstreept ons kwaliteitsniveau. Op als onze onderzoeksopdrachten zijn de Algemene Voorwaarden van de Animal Sciences Group van toepassing. Deze zijn gedeponeerd bij de Arrondissementsrechtbank Zwolle. 


\section{Inhoud}

$\begin{array}{lr}\text { Inhoud } & \mathbf{3}\end{array}$

$\begin{array}{ll}\text { Woord vooraf } & \mathbf{5}\end{array}$

$\begin{array}{lr}\text { Samenvatting } & 7\end{array}$

$\begin{array}{llr}1 & 1 \text { Inleiding } & 11\end{array}$

$\begin{array}{lll}1.1 & \text { Achtergrond } & 11\end{array}$

$\begin{array}{lll}1.2 & \text { Doelen } & 11\end{array}$

$\begin{array}{lll}1.3 & \text { Aanpak } & 12\end{array}$

1.4 Opbouw rapport $\quad 13$

2 Rekenregels voor de enterische methaanemissie op het melkveebedrijf

$\begin{array}{lll}2.1 & \text { Algemeen } & 14\end{array}$

2.2 Materiaal en methoden $\quad 14$

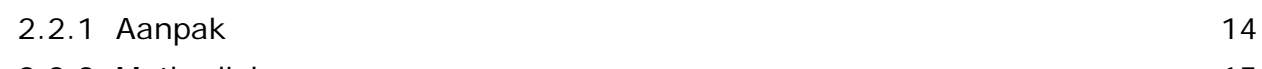

$\begin{array}{ll}2.2 .2 \text { Methodiek } & 15\end{array}$

2.3 Resultaten 16

2.3.1 Definiëren basisrantsoenen $\quad 16$

2.3.2 Impact EF lijsten op berekende methaanemissie $\quad 18$

2.3.3 Impact rantsoensamenstelling op EF van graskuil en snijmaiskuil $\quad 18$

2.3.4 Interpolatie van EF lijsten $\quad 20$

$\begin{array}{ll}2.3 .5 \text { Jongvee } & 21\end{array}$

$\begin{array}{lll}2.4 & \text { Conclusies } & 22\end{array}$

$3 \quad$ Methaanemissie en voeropnameniveau $\quad 23$

3.1 Algemeen $\quad 23$

3.2 Materiaal en methoden $\quad 23$

3.2.1 Aanpak 23

3.2.2 Rekenmethodiek 23

3.2.3 Data 23

$\begin{array}{lll}3.3 & \text { Resultaten } & 23\end{array}$

$\begin{array}{lll}3.4 & \text { Conclusies } & 24\end{array}$

$4 \quad$ Methaanemissie en ruwvoerkwaliteit $\quad 25$

$\begin{array}{lll}4.1 & \text { Algemeen } & 25\end{array}$

4.2 Materiaal en methoden $\quad 25$

4.2.1 Aanpak $\quad 25$

4.2.2 Rekenmethodiek en data $\quad 25$

4.3 Resultaten $\quad 26$

4.3.1 Vers gras $\quad 26$

4.3.2 Ingekuild gras $\quad 26$

4.3.3 Ingekuilde snijmais 28

$\begin{array}{ll}4.3 .4 & \text { Overige ruwvoeders } \\ & 28\end{array}$

$\begin{array}{lll}4.4 & \text { Conclusies } & 28\end{array}$ 
5.1 Algemeen 29

5.2 Materiaal en methoden $\quad 29$

5.2.1 Aanpak 29

5.2.2 Rekenmethodiek 30

$\begin{array}{lll}5.3 & \text { Resultaten } & 30\end{array}$

5.3.1 Algemeen 30

5.3.2 Methaanemissie en theoretische kosteneffectiviteit 32

$\begin{array}{lll}5.4 & \text { Praktische kosteneffectiviteit } & 32\end{array}$

5.4.1 Algemeen 32

5.4.2 Praktijktest 'Optimaliseren mengvoeders naar methaanemissie' 32

5.5 Conclusies $\quad 34$

$6 \quad$ Methaanemissie en mest-handling $\quad 35$

$\begin{array}{lll}6.1 & \text { Algemeen } & 35\end{array}$

6.1.1 Achtergrond 35

6.1.2 Dierfactoren 36

6.1.3 Mesteigenschappen 37

$\begin{array}{lll}6.2 & \text { Mestopslag in de stal } & 37\end{array}$

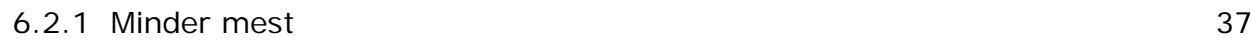

6.2.2 Vaste mest of drijfmest 38

6.2.3 Mest kort opslaan 38

6.2.4 Mest koelen $\quad 39$

6.2.5 Mestputten schoonmaken $\quad 39$

$\begin{array}{lll}6.3 & \text { Mestopslag buiten de stal } & 40\end{array}$

6.3.1 Mest afdekken $\quad 40$

6.3.2 Drijfmest beluchten $\quad 41$

6.3.3 Vaste mest composteren $\quad 42$

6.3.4 Drijfmest verdunnen $\quad 43$

6.4 Mest bewerken/verwerken $\quad 43$

6.4.1 Mest scheiden $\quad 43$

6.4.2 Mest vergisten $\quad 43$

$\begin{array}{lll}6.5 & \text { Overig } & 44\end{array}$

6.5.1 Toevoegmiddelen $\quad 44$

$\begin{array}{ll}6.5 .2 \text { Affakkelen } & 45\end{array}$

6.5.3 Beweiden $\quad 45$

6.6 Methaanemissie bij mest aanwenden $\quad 45$

$\begin{array}{lll}6.7 & \text { Conclusies } & 46\end{array}$

$\begin{array}{lll}6.8 & \text { Conclusies } & 47\end{array}$

$\begin{array}{lll}6.9 & \text { Rekenregels } & 47\end{array}$

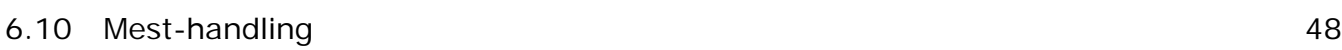

Literatuur 


\section{Woord vooraf}

Voor u ligt het rapport 'Rekenregels voor de methaanemissie op het melkveebedrijf: het handelingsperspectief van het voerspoor inzichtelijk maken met de KringloopWijzer'. Het rapport geeft weer hoe het handelingsperspectief voor methaanreductie via het voerspoor met rekenregels in de KringloopWijzer vastgesteld kan worden. Daarmee wordt het effect van sturen op voerfactoren ingerekend en wordt het voor een individueel melkveebedrijf in Nederland mogelijk de relevantie duidelijk te maken van methaanemissiereductie via het voerspoor. Het rapport bevat ook een review naar de mogelijkheden om methaanemissie op een melkveebedrijf (verder) te reduceren via mesthandling.

In dit project heeft een team van Wageningen UR Livestock Research samengewerkt met vertegenwoordigers van het Nederlandse diervoederbedrijfsleven:

I. Gantois (DSM), J. Goelema (de Heus), M. Hoogenboom (de Samenwerking), H. van Laar (Nutreco), K. Molenaar (Boerenbond Deurne), J. Temmink (Forfarmers), J. Veneman (Cargill) en E. Weurding (Agrifirm).

Het onderzoek is financieel mogelijk gemaakt door het onderzoeksprogramma Feed4Foodure, vanuit de ambitie om een substantiële bijdrage te leveren aan een duurzame en gezonde veehouderij in Nederland. Feed4Foodure is een publiek-private samenwerking tussen het ministerie van Economische Zaken en een consortium van verschillende partijen uit het diervoederbedrijfsleven en de dierlijke productieketen.

De samenwerking in uitvoering en financiering en de betrokkenheid van mensen geeft aan dat de resultaten van dit rapport een nationaal belang dienen. Het is belangrijk om scherp te blijven letten op mogelijkheden om de emissie vanuit de melkveehouderij scherp te kwantificeren en vervolgens waar mogelijk te beperken. I k vertrouw erop dat dit rapport daar in belangrijke mate aan bij kan dragen.

Met vriendelijke groeten,

Dr. Ir. G. (Gert) van Duinkerken

Afdelingshoofd Diervoeding 


\section{Samenvatting}

Het Nederlandse diervoerbedrijfsleven en de zuivelketen willen de footprint van melk verkleinen door onder andere de C-kringloop efficiënter te maken. Daarbij heeft de individuele melkveehouder een sleutelrol. Om de on-farm emissies bedrijfsspecifiek in beeld te brengen is besloten om de kringloopwijzer als monitoringsinstrument te gebruiken.

De voerketen kan via reductie van de enterische methaanemissie een flinke bijdrage leveren aan de efficiëntieverbetering in de C-kringloop op het melkveebedrijf, maar de KringloopWijzer kent nog geen rekenregels om het effect van het voerspoor goed door te rekenen. Het onderzoeksprogramma Feed4Foodure heeft daarom opdracht gegeven om rekenregels voor de enterische methaanemissie op te stellen en de impact en kosteneffectiviteit aan te geven van methaanreductie via het aanpassen van de grondstoffensamenstelling van mengvoeders. Daarnaast is gevraagd te inventariseren welke mogelijkheden mest-handling biedt voor verdere reductie van de methaanemissie op melkveebedrijven.

\section{Rekenregels}

Het voorliggende onderzoek is gebaseerd op eerder onderzoek waarin is geconcludeerd dat de bedrijfsspecifieke methaanemissie het best berekend kan worden met behulp van emissiefactoren (EF, in $\mathrm{g} \mathrm{CH}_{4} / \mathrm{kg}$ droge stof). Die EF zijn voor ieder voedermiddel afgeleid met behulp van de Nederlandse IPCC Tier 3 benadering en de resultaten zijn in een lijst weergegeven (EF-lijst). Op basis van die EFlijst en de grondstoffensamenstelling van het bedrijfsspecifieke rantsoen kan een gewogen gemiddelde voor de methaanemissie per $\mathrm{kg}$ droge stof van het rantsoen worden berekend.

Voor een goede schatting van de enterische methaanemissie per $\mathrm{kg}$ droge stof van een voedermiddel is het nodig om rekening te houden met 3 belangrijke factoren: Rantsoensamenstelling,

voeropnameniveau en ruwvoerkwaliteit.

Het effect van de rantsoensamenstelling op de enterische methaanemissie van melkvee kan goed geschat worden via rantsoendifferentiatie naar het aandeel snijmais in het ruwvoerdeel van het rantsoen. Daarbij moet gebruikt gemaakt worden van interpolatie met minimaal $3 \mathrm{EF}$-lijsten (voor rantsoenen met $0 \%, 40 \%$ en $80 \%$ snijmais in het ruwvoer). Deze benadering voldoet ook voor het oudere jongvee dat ruwvoer opneemt en past dus bij de benadering van de KringloopWijzer om voor rantsoenen op veestapelniveau te rekenen. $\mathrm{Er}$ is bij het berekenen van de $\mathrm{CH}_{4}$ emissies op veestapelniveau wellicht een correctie (vermindering) nodig voor jonge kalveren met een rantsoen dat slechts een gering aandeel ruwvoer bevat.

Het effect van het voeropnameniveau blijkt vrijwel lineair te zijn en kan daarom als correctiefactor op de berekende methaanemissie van een rantsoen worden toegepast. Bij rantsoendifferentiatie naar het aandeel snijmais in het ruwvoerdeel van het rantsoen is tussen $0 \%$ en $80 \%$ snijmais een verschil van $0,02 \mathrm{~g}$ methaan $/ \mathrm{kg}$ droge stof geconstateerd in het effect van voeropnameniveau. Voor diezelfde rantsoenen nam bij een stijgende voeropname (van 14 tot $24 \mathrm{~kg}$ ds/dag) de methaanemissie per $\mathrm{kg}$ ds vrijwel constant af. Rondom de gemiddelde droge stof opname van melkvee in Nederland (18,5 kg ds per dier per dag) zal kunnen worden volstaan met een correctie van de berekende methaanemissie per $\mathrm{kg}$ ds van 0,21 g methaan per $\mathrm{kg}$ ds afwijking in de voeropname ten opzichte van de gemiddelde voeropname van 18,5 kg ds per dier per dag (rekenwijze: actuele ds-opname minus 18,5 maal 0,21).

Het effect van ruwvoerkwaliteit is voor vers gras en graskuil vergelijkbaar. De methaanemissie $(\mathrm{g} / \mathrm{kg}$ ds) neemt toe met zwaarte van de snede en het aantal dagen hergroei. Uit een eerste analyse voor graskuilen bleek dat de methaanemissie een relatie vertoont met verschillende voerkenmerken, waarvan het NDF- en suikergehalte perspectief lijken te bieden. Vooralsnog wordt echter volstaan met de aannames zoals opgenomen in Feedprint voor een hoge en lage opbrengst van vers gras en van graskuil, met in beide gevallen een maximaal verschil in methaanemissie van $4 \mathrm{~g}$ methaan $/ \mathrm{kg}$ 
gras(kuil) droge stof tussen een hoge en lage opbrengst. De methaanemissie ( $\mathrm{g} / \mathrm{kg}$ ds) voor vers gras is ongeveer $1 \mathrm{~g} \mathrm{CH}_{4} / \mathrm{kg}$ ds hoger dan voor graskuil. Deze verschillen zijn niet toepasbaar voor extreme groeiomstandigheden en minder reguliere vormen van bedrijfsvoering en graslandmanagement.

Het effect van ruwvoerkwaliteit is voor snijmaissilage te relateren aan voerkenmerken. Daarbij kan het zetmeelgehalte of het NDF-gehalte gebruikt worden. De methaanemissie van een gemiddelde maiskuil daalt per $10 \mathrm{~g}$ stijging van het zetmeelgehalte met $0,5 \mathrm{~g}$ methaan/ $\mathrm{kg}$ droge stof snijmais en daalt per $10 \mathrm{~g}$ daling van het NDF-gehalte met $0.8 \mathrm{~g}$ methaan $/ \mathrm{kg}$ droge stof snijmais.

\section{I mpact en kosteneffectiviteit grondstoffensamenstelling van mengvoeders}

De KringloopWijzer kan worden uitgebreid met nauwkeuriger informatie over de methaanemissie per $\mathrm{kg}$ mengvoer. Daarmee wordt het effect zichtbaar van methaanreductie via het aanpassen van de receptuur van mengvoeders. De relevantie en kosteneffectiviteit van die werkwijze is in de voorliggende studie onderzocht. Dat is gebeurd door de EF per voedermiddel mee te nemen in de lineaire programmering voor enkele typen mengvoer (standaard, eiwitrijke en zetmeelrijk). Eerst is een basisoptimalisatie uitgevoerd zonder eis voor de methaanemissie en daarna is geoptimaliseerd naar $5 \%$ en $10 \%$ reductie van de methaanemissie $(\mathrm{g} / \mathrm{kg} \mathrm{ds}$ ) uit de basisoptimalisatie. Het bleek in alle gevallen mogelijk om, met behoud van de voederwaarde en nutriëntengehalten, $10 \%$ reductie in methaanemissie te realiseren via aanpassing van de grondstoffensamenstelling van mengvoeder. Daarmee is de relevantie van deze aanpak aangetoond.

Vervolgens is gekeken naar de impact op de kosteneffectiviteit (kosten van het grondstoffenpakket) van die $5 \%$ en $10 \%$ methaanreductie. De kostprijs voor het verlagen van de methaanemissie per $\mathrm{kg}$ mengvoer bleek bij de grondstoffenprijzen van 2015/2016 te variëren van $+0,09$ tot $+2,83 € / 100 \mathrm{~kg}$ mengvoer. De stijging van de kostprijs was voor het zetmeelrijke mengvoer het grootst en voor het standaard mengvoer het laagst. Het eisenpakket en de striktheid waarmee de eisen worden opgevolgd is daarbij bepalend voor de te realiseren kosteneffectiviteit. Dat betekent dat zich in de praktijk situaties zullen voordoen waarbij de kosteneffectiviteit zwaarder weegt dan een voorgenomen emissiereductie per $\mathrm{kg}$ mengvoer.

Uit een pilot naar prakrijktoepassing bleek dat de nieuwe rekenregels in combinatie met de drie EF lijsten makkelijk implementeerbaar zijn in de LP programmatuur van de diervoederindustrie.

\section{I nventarisatie reductie methaanemissie via mest-handling}

Het effect van mest-handling op de methaanemissie van het melkveebedrijf kan groot zijn. Het gemiddelde Nederlandse melkveebedrijf heeft een ligboxenstal waarin de mest als drijfmest wordt opgeslagen. Op zo'n bedrijf is ongeveer $20 \%$ van de methaanemissie afkomstig uit mest. Deze bron van methaan kan flink gereduceerd worden (30\%-90\%), waarmee de totale methaanemissie op het gemiddelde Nederlandse melkveebedrijf 6\%-18\% kan worden verminderd. Daarmee wordt de totale broeikasgasemissie van het melkveebedrijf met 3\% - 9\% verminderd.

Vermindering van de methaanemissie uit mest kan gepaard gaan met een toename van de lachgasemissie uit mest. Hierdoor wordt het effect van reductie van de methaanemissie op de totale broeikasgasemissie van het melkveebedrijf gedrukt. Dit effect is echter klein, omdat van de $\mathrm{CO}_{2}$ equivalenten uit mest slechts ongeveer $4 \%$ van de lachgasemissie komt.

De methaanemissie uit mest ( $\mathrm{kg} \mathrm{CO}$ equivalenten per jaar) op het melkveebedrijf wordt bepaald door de hoeveelheid geproduceerde mest, de mestsamenstelling, de mestopslag en eventuele bewerkingen van de mest. De methaanemissie bij aanwenden is verwaarloosbaar klein.

Drijfmest

Opties voor verminderen methaanemissie uit drijfmest, inclusief reductiepotentie (in \% van de oorspronkelijke methaanemissie uit mest):

- De hoeveelheid geproduceerde mest. Er zijn geen gegevens m.b.t. de reductiepotentie.

- De mestsamenstelling. Belangrijke factoren zijn pH, zuurstofgehalte en ammoniumgehalte. 
- Verlagen van de $\mathrm{pH}$ door toevoegen van zuren en antibacteriële middelen. Reductiepotentie afhankelijk van toevoegmiddel, $65 \%-85 \%$.

o Verhogen van het zuurstofgehalte door beluchten. Reductiepotentie 50\%-60\%.

o Verhogen ammoniumgehalte (tegengaan ammoniakemissie). Reductiepotentie niet bekend.

- De mestopslag. Belangrijke factoren zijn de duur van mestopslag, de temperatuur in de mestopslag en het afdekken van de mest.

o Opslagduur in de stal verkorten (mestopslag buiten de stal). Reductiepotentie $50 \%-85 \%$.

o Temperatuur verlagen door koelen mest (in of buiten de stal). Reductiepotentie $30 \%-45 \%$.

o Mest afdekken met strolaag. Reductiepotentie 5\% - 25\%.

- Mestbewerking. Mogelijkheden zijn mest vergisten, mest scheiden en mest verdunnen.

o Vergisten (in combinatie met opslagduur in de stal verkorten). Reductiepotentie $30 \%-70 \%$.

o Scheiden en de dunne en dikke fractie apart opslaan. Reductiepotentie $10 \%-40 \%$.

o Verdunnen door toevoegen van water. Reductiepotentie 50\% - 60\%.

Vaste mest

De methaanemissie uit mest ( $\mathrm{kg} \mathrm{CO} 2$ equivalenten per jaar) op het melkveebedrijf verminderen door over te stappen van een drijfmestsysteem naar een systeem met vaste mest. Mits het vaste mest systeem goed wordt gemanaged is de reductiepotentie $60 \%-70 \%$ (in \% van de oorspronkelijke methaanemissie uit drijfmest).

Opties voor verminderen methaanemissie uit vaste mest, inclusief reductiepotentieel (in \% van de oorspronkelijke methaanemissie uit drijfmest):

- Afdekken met stro. Reductiepotentie afhankelijk van dikte strolaag en temperatuur, $40 \%-80 \%$.

- Composteren van de mest. De reductiepotentie is laag met zeer wisselende resultaten waarbij de methaanemissie ook kan toenemen.

Overige opties om de methaanemissie uit mest te verminderen

- Affakkelen geproduceerde methaan. In combinatie met mestopslag buiten de stal in een afgesloten ruimte en het verkorten van de verblijfduur van mest in de stal. Reductiepotentie niet bekend maar lijkt zeer groot (indien werkbaar). 


\title{
$1 \quad$ Inleiding
}

\subsection{Achtergrond}

\begin{abstract}
Aanleiding
Het Nederlandse diervoerbedrijfsleven is actief betrokken bij de mogelijkheden om de koolstofkringloop efficiënter te maken en de broeikasgasemissie te reduceren. Ook de zuivelketen wil de C-kringloop efficiënter maken en heeft besloten om de emissie van methaan, kooldioxide en de mobiliteit van organische stof in de bodem bedrijfsspecifiek in beeld te brengen met het monitoringsinstrument de KringloopWijzer (Aarts et al, 2015). Daarmee ligt de focus op de on-farm emissies. De voerketen kan in potentie een substantiële bijdrage leveren aan efficiëntieverbetering in de C-kringloop op een melkveebedrijf (Šebek et al, 2014). Echter, de KringloopWijzer kent nog geen rekenregels om het effect van de bijdrage van de voerketen door te rekenen. Het onderzoeksprogramma Feed4Foodure ${ }^{1}$ heeft daarom opdracht gegeven om die rekenregels voor de KringloopWijzer op te stellen en daarnaast te inventariseren welke mogelijkheden mest-handling biedt voor verdere reductie van de methaanemissie op melkveebedrijven.
\end{abstract}

I mpact

In de zuivelketen komt ongeveer 75\% van de broeikasgasemissie van het melkveebedrijf en de broeikasgasemissie op het melkveebedrijf bestaat voor ongeveer $10 \%$ uit kooldioxide (fossiele brandstof), $25 \%$ lachgas (bemesting) en $65 \%$ methaan (vertering voer $52 \%$ en mest $13 \%$ ). Daaruit blijkt het belang van goede rekenregels voor de impact van de voerketen op de broeikasgasemissie; ongeveer de helft van de on-farm broeikasgasemissie en ongeveer 35-40\% van de broeikasgasemissie in de zuivelketen is gerelateerd aan de microbiële afbraak van voer (enterisch methaan).

Reductiemogelijkheden voor de enterische methaanemissie moeten gezocht worden in verbetering van de benutting van het opgenomen voer (i.c. rantsoensamenstelling). Uit een vorig Feed4Foodure project (Šebek et al, 2014) bleek dat binnen de normale variatie in Nederlandse rantsoenen een reductiepotentie ligt van ongeveer $15-20 \%$. Daarmee kan de totale emissie van broeikasgassen op het melkveebedrijf met ongeveer $8-10 \%$ verminderd worden. Ten opzichte van het referentiejaar 1990 is de reductiepotentie wat groter (20-25\% voor methaan en $10-13 \%$ voor de totale broeikasgasemissie).

\section{KringloopWijzer}

De KringloopWijzer (Aarts et al, 2015) is een rekenmodel waarvan de kern bestaat uit wetenschappelijk onderbouwde rekenregels (Schröder e.a., 2014 en 2016). Wetenschappelijke onderbouwing is essentieel ter ondersteuning van het traject 'borging en handhaving'. Het model berekent in het onderdeel BEC de methaanemissie van de veestapel, maar de rekenregels in de KringloopWijzer versie 2014 zijn onvoldoende specifiek om het effect van rantsoensamenstelling nauwkeurig door te rekenen. Aanpassing van deze rekenregels is belangrijk vanwege de potentie om via het voerspoor de broeikasgasemissie op het melkveebedrijf te verlagen.

\subsection{Doelen}

\section{Rekenregels KringloopWijzer}

Het eerste doel van dit onderzoek was het genereren van rekenregels waarmee in de KringloopWijzer het effect van voermaatregelen op de enterische methaanemissie kan worden doorgerekend. Daarnaast moest inzicht gegeven worden in de nauwkeurigheid waarmee de enterische methaanemissie van de veestapel van het individuele melkveebedrijf via emissiefactoren (EF)

\footnotetext{
${ }^{1}$ Feed4Foodure is een publiek-private samenwerking tussen het ministerie van Economische Zaken en een consortium van verschillende partijen uit de diervoedingsindustrie en de dierlijke productieketen.
} 
berekend wordt. Op basis daarvan werd besloten welke rekenwijze voor het vaststellen van EF in de KringloopWijzer gehanteerd moest worden.

Mogelijkheden mengvoedersamenstelling

Het tweede doel van dit onderzoek was antwoord geven op de vraag of het zinvol is de KringloopWijzer uit te breiden met geavanceerde (=nauwkeuriger) rekenregels voor de methaanemissie per eenheid mengvoer. In dit verband wordt met zinvol bedoeld dat het sturen van de receptuur van mengvoeders op een economisch verantwoorde wijze bijdraagt aan een relevante reductie van de methaanemissie op het melkveebedrijf en/of in de diervoederketen.

Mogelijkheden mest-handling

Het derde doel van dit onderzoek was het inventariseren van de mogelijkheden om de methaanemissie te reduceren via mest-handling. Het effect van mest-handling op de methaanemissie van het melkveebedrijf moest in grote lijnen gekwantificeerd worden (orde van grootte) om inzicht te krijgen in de relevantie voor de praktijk.

\subsection{Aanpak}

\section{Algemeen}

Om het handelingsperspectief vanuit verschillende invalshoeken te belichten is voor dit project een begeleidingsteam samengesteld met medewerkers van WUR Livestock Research en met vertegenwoordigers van het diervoederbedrijfsleven (zie 'Woord vooraf').

\section{Rekenregels}

De 'state of the art' berekening van de methaanemissie uit het maagdarmkanaal van melkvee is vastgelegd in het pensmodel van Dijkstra et al (1992), is uitgebreid met een module voor methaanberekening voor de dunne darmvertering en dikke darm fermentatie (Mills et al, 2001) en een herziene beschrijving van de productie van waterstof (Bannink et al, 2008). Het model is als een IPCC Tier 3 methode geaccordeerd, hetgeen onder andere inhoudt dat de wetenschappelijke onderbouwing geborgd is. De Tier 3 methode is beschreven in een peer-reviewed tijdschrift door Bannink et al (2011) en in een werkdocument voor Wettelijke Onderzoekstaken Natuur \& Milieu (Bannink, 2011). Volgens een studie van Šebek et al (2014), is de beste mogelijkheid om de rekenregels in de KringloopWijzer aan te passen gebaseerd op het gebruik van specifieke methaanemissiefactoren (EF) die met het pensmodel zijn gegenereerd. Daarvoor moet voor alle in de melkveehouderij te gebruiken voedermiddelen c.q. veevoedergrondstoffen de EF worden vastgesteld.

De nauwkeurigheid en het onderscheidend vermogen van de methode om via EF de methaanemissie van de veestapel van het individuele melkveebedrijf te berekenen is nog niet wetenschappelijk onderbouwd. Weliswaar is door gebruik te maken van kengetallen die met het pensmodel zijn gegenereerd de onderbouwing van die rekenregels op indirecte wijze geborgd, maar alleen publicatie van die rekenregels zelf kan dienen als wetenschappelijke onderbouwing van deze aanpak (niet voorzien in het voorliggende project).

Mengvoedersamenstelling

Met de EF van grondstoffen kan de grondstoffensamenstelling (receptuur) van mengvoeders geoptimaliseerd worden naar methaanemissie. De relevantie van deze mogelijkheid wordt onderzocht door het reductiepotentieel en de bijbehorende kosteneffectiviteit in beeld te brengen voor enkele typen mengvoeder.

Mest-handling

Mest-handling kan een interessant handelingsperspectief voor reductie van de methaanemissie bieden (Šebek et al, 2014). In het voorliggende onderzoek wordt dit via een literatuuronderzoek verder onderzocht. Daarbij wordt geïnventariseerd welke kennis beschikbaar is over reductieopties, inclusief het reductiepotentieel en de kosteneffectiviteit. 


\subsection{Opbouw rapport}

Hoofdstuk 1 geeft de achtergrond weer van de vraag om nieuwe rekenregels voor de enterische methaanemissie in de kringloopwijzer en van het onderzoek naar de mogelijkheden om via mesthandling de methaanemissie van het melkveebedrijf te verkleinen.

Hoofdstuk 2 beschrijft hoe de enterische methaanemissie gerelateerd is aan de rantsoensamenstelling en op welke basis onderscheid gemaakt moet worden tussen rantsoenen. Daarbij wordt de vraag beantwoord of het werken met lijsten met EmissieFactoren (EF) onderscheidend genoeg is voor het effect van rantsoensamenstelling, en zo ja, hoeveel standaardsets met EF nodig zijn voor een nauwkeurige schatting van de enterische methaanemissie.

Hoofdstuk 3 en 4 gaan in op de vraag hoe de methodiek in hoofdstuk 2 verder genuanceerd kan worden naar ruwvoerkwaliteit en voeropnameniveau. Deze twee kenmerken beïnvloeden het functioneren van de pens en hebben daarmee effect op de enterische methaanemissie. Dat effect blijkt ingerekend te kunnen worden via correctie van de basisrekenregels uit hoofdstuk 2 .

Hoofdstuk 5 laat de relevantie en kosteneffectiviteit zien van de receptuur (grondstoffensamenstelling) van mengvoeders om de methaanemissie van het melkveebedrijf te verminderen. Dat gebeurt via lineaire programmering met een eis voor methaanemissie in $\mathrm{g} / \mathrm{kg}$ product op basis van verschillende EF lijsten.

Hoofdstuk 6 geeft een literatuuroverzicht met betrekking tot de bijdrage van mest-handling aan de reductie van de methaanemissie op het melkveebedrijf. Waar mogelijk is die bijdrage kwantitatief gemaakt.

Tenslotte worden in hoofdstuk 7 de belangrijkste conclusies samengevat.

In Bijlage 1 worden de EF lijsten voor de basisrantsoenen 0\%,40\% en $80 \%$ snijmaiskuil in het ruwvoerdeel gegeven, in Bijlage 2 de resultaten van de basisoptimalisatie voor productiebrok, eiwitbrok en zetmeelbrok en in Bijlage 3 de wijziging in de grondstoffensamenstelling (\%) van basisoptimalisatie naar optimalisaties voor respectievelijk 5\% en $10 \%$ methaanreductie voor productiebrok, eiwitbrok en zetmeelbrok. 


\section{Rekenregels voor de enterische methaanemissie op het melkveebedrijf}

\subsection{Algemeen}

De KringloopWijzer (versie 2014) bevat voor het berekenen van de enterische methaanemissie de IPCC Tier 2 rekenregels voor herkauwers, maar deze hebben onvoldoende onderscheidend vermogen om het methaanreducerende effect van voermaatregelen te kwantificeren. Volgens een studie van Šebek et al (2014) is de beste mogelijkheid om de rekenregels in de KringloopWijzer aan te passen gebaseerd op het gebruik van specifieke methaanemissiefactoren (EF) die met het model van Bannink et al (2011) zijn gegenereerd. Hoe die aanpassing van de rekenregels precies moet gebeuren was de kern van het onderzoek dat in dit rapport wordt beschreven.

Het gebruik van de Nederlandse IPCC Tier 3 benadering voor de berekening van EF voor de methaanemissie uit het maagdarmkanaal van melkvee (Bannink et al, 2011) borgt de onderbouwing van de hier gevolgde methode. Dat betekent niet dat daarmee ook de nauwkeurigheid en het onderscheidend vermogen van de voorgestelde aanpassing van de rekenregels in de KringloopWijzer zijn onderbouwd. Daarvoor is een wetenschappelijke publicatie nodig die de 'EF methode' beschrijft en evalueert (niet voorzien in het voorliggende project).

\subsection{Materiaal en methoden}

\subsubsection{Aanpak}

De in de KringloopWijzer op te nemen berekening van de enterische methaanemissie op basis van EFlijsten moet voldoende nauwkeurig zijn voor de hele range van de voor Nederland normale variatie in rantsoenen. Om die normale variatie te omvatten zijn in dit onderzoek 5 basisrantsoenen gedefinieerd ( gemiddeld, de twee uitersten en de twee tussen de beide uitersten en het gemiddelde). Het kiezen van de basisrantsoenen heeft plaats gevonden in overleg met het begeleidingsteam van het project, bestaande uit vertegenwoordigers van het Nederlandse diervoederbedrijfsleven. Daarbij is gekozen voor het aandeel snijmaissilage in het ruwvoerdeel van het rantsoen als onderscheidende factor. De beide uiterste basisrantsoenen zijn dan ook gedefinieerd als minimaal $(=0 \%)$ en maximaal $(=80 \%)$ aandeel snijmaissilage in het ruwvoerdeel van het rantsoen. Daaruit volgt dat het gemiddelde rantsoen is gedefinieerd als $40 \%$ snijmaissilage en de twee tussenliggende rantsoenen als respectievelijk $20 \%$ en $60 \%$ snijmaissilage in het ruwvoerdeel van het rantsoen.

De meest geschikte methode om de enterische methaanemissie te berekenen is het gebruik van het model van Bannink et al, 2011 . Daarom is dit model gebruikt om voor de twee gedefinieerde uiterste basisrantsoenen ( $0 \%$ en $80 \%$ snijmaissilage) de methaanemissie vast te stellen en deze 'model methaanemissies' zijn gebruikt als standaardwaarden. Vervolgens is met de 'EF rekenmethode' voor dezelfde twee basisrantsoenen de methaanemissie berekend en vergeleken met de standaardwaarden.

Wanneer de methaanemissie voor de beide uiterste basisrantsoenen (van de voor Nederland normale variatie) goed wordt geschat via de EF lijsten, is het vervolgens de vraag of de methaanemissie van de tussenliggende rantsoenen ook goed geschat kan worden vanuit diezelfde EF lijsten. Voor de berekening van de methaanemissie van de tussenliggende rantsoenen is interpolatie van de waarden in de EF lijsten voor de beide uiterste basisrantsoenen toegepast. 


\subsubsection{Methodiek}

\section{Algemeen}

De hoeveelheid enterische methaan die gevormd wordt bij de vertering van $1 \mathrm{~kg}$ droge stof van een voedermiddel wordt bepaald door de combinatie van 'eigenschappen voedermiddel' en 'functioneren pens'. Het functioneren van de pens wordt in hoofdlijn bepaald door 3 kenmerken: rantsoen, voeropname (c.q. melkproductie) en de eigenschappen van het voer (voerkwaliteit). Het model van Bannink et al, 2011 neemt al deze kenmerken dan ook mee in de berekeningen.

Voor het beantwoorden van de vraag of het werken met EF lijsten voldoet voor de rekenregels voor de KringloopWijzer kan variatie in opnameniveau en ruwvoerkwaliteit verwarrend werken. Daarom is in dit onderdeel van het onderzoek niet gevarieerd met opnameniveau en voerkwaliteit.

Voor opnameniveau is een algemeen effect op de methaanemissie aangetoond (Reynolds et al, 2010). Aangenomen werd dat een zelfde effect aangehouden kan worden voor de EF van voedermiddelen voor de in Nederland gangbare variatie in rantsoensamenstelling, waardoor het niet nodig was om het effect van rantsoensamenstelling en voeropnameniveau simultaan te modelleren.

Voor voerkwaliteit wordt de variatie in de kwaliteit van mengvoedergrondstoffen door het CVB weergegeven door ze als afzonderlijke grondstoffen op te nemen in de lijst van veevoedergrondstoffen (CVB, 2011). Daarmee zijn de kwaliteitsverschillen voor veevoedergrondstoffen verwerkt in de EF lijsten. Ook voor ruwvoeders geeft de CVB verschillende kwaliteiten per voedermiddel, maar voor de beide belangrijkste ruwvoeders (i.c. graskuil en snijmaiskuil) is in dit project onderzocht of het zinvol is om 'traploos' te werken met schattingsformules voor de EF voor methaan (hoofdstuk 5).

\section{Activiteiten}

1. Vaststellen aantal basisrantsoenen, definiëren van de rantsoenkenmerken en genereren EF lijsten voor de beide uiterste rantsoenen (extremen in aandeel snijmaiskuil in ruwvoer; i.c. $0 \%$ en $80 \%$ )

2. Vaststellen impact rantsoensamenstelling op de methaanemissie

3. Evalueren rekenmethodiek EF lijsten

Ad 1. Het begeleidingsteam heeft eerst vastgesteld hoe de basisrantsoenen er in hoofdlijnen uit moeten zien en vervolgens besloten dat de details van de basisrantsoenen worden vastgesteld met behulp van het koemodel (Zom, 2014; Zom et al, 2012a; Zom et al, 2012b). Daarbij is uitgegaan van wat een gemiddelde Nederlandse veestapel van die basisrantsoenen opneemt en welke melkproductie daar bij hoort.

Ad 2. Voor 8 kenmerkende grondstoffen is de EF uitgerekend voor de rantsoenen met $0 \%$ en $80 \%$ snijmaiskuil in ruwvoer. Als criterium is aangehouden dat het werken met verschillende EF lijsten relevant wordt bij een verschil van $5 \%$ en dat het bij een verschil van $10 \%$ of meer essentieel wordt.

Ad 3. Interpolatie van de EF lijsten van de beide uiterste basisrantsoenen moet tot een goede schatting leiden voor de methaanemissie van de tussenliggende rantsoenen. Dit is onderzocht door deze uitkomsten te vergelijken met de uitkomsten van het model Bannink et al, 2011. Als de nauwkeurigheid onvoldoende blijkt te zijn wordt de interpolatie-methode uitgebreid met een derde basisrantsoen (de beide uiterste en het gemiddelde basisrantsoen).

\section{Vaststellen EF per grondstof}

Het berekenen van een EF per voedermiddel/grondstof kan meestal niet gebeuren door te doen alsof het voedermiddel enkelvoudig vervoederd zou worden. Daarom moet de EF worden afgeleid uit de verandering in de methaanemissie van het totale rantsoen ten gevolge van een (klein) verschil in het aandeel (\% in DS) van de te onderzoeken grondstof in het rantsoen. Dit aandeel moet klein blijven om de aard van het rantsoen niet te veranderen, zodat een EF waarde wordt afgeleid die bij het oorspronkelijke rantsoen past. Tegelijkertijd mag die verandering niet te klein zijn, omdat bij terugvertalen naar rantsoenniveau de schattingsfout met dezelfde factor wordt vermenigvuldigd. Op basis van eerder onderzoek waarin EF waarden zijn afgeleid voor FeedPrint bleek een aandeel van 5\% uitwisseling van de rantsoen DS voor de grondstof DS een geschikte keuze te zijn (Vellinga, 2013). Een uitwisseling van $10 \%$ in plaats van $5 \%$ gaf doorgaans een EF waarde die minder dan $10 \%$ afweek van de EF waarde berekend met $5 \%$ uitwisseling. Echter, het verschil tussen de EF-waarden berekend met $10 \%$ uitwisseling en $5 \%$ uitwisseling nam toe naarmate de chemische samenstelling van het 
product eenzijdiger is (bijv. zeer eiwitrijk, of zeer zetmeelrijk). Een zeer geringe uitwisseling met slechts $1 \%$ maakt de berekende EF waarde gevoelig voor kleine verschillen in berekende methaanemissie. Immers, hoe kleiner het \% uitwisseling, hoe kleiner het getal waardoor de verandering in methaanemissie wordt gedeeld. Op basis van deze afwegingen is voor een uitwisseling met 5\% gekozen. Een aandeel van 5\% komt ongeveer overeen met $1 \mathrm{~kg}$ droge stof per dag en dat kan voor grondstoffen met veel zetmeel, suikers en/of vet alsnog te veel zijn en de aard van het rantsoen aanzienlijk veranderen. Daarom is in dit project eveneens onderzocht of een uitwisseling van slechts $1 \%$ tot wezenlijk andere EF waarden leidt.

\subsection{Resultaten}

\subsubsection{Definiëren basisrantsoenen}

De meeste Nederlandse rantsoenen kennen een ruwvoerdeel dat overwegend bestaat uit graskuil en/of maiskuil, maar waarvan het aandeel van beide sterk kan variëren. Daarom worden de basisrantsoenen onderscheiden op grond van het aandeel snijmais (\% snijmais) c.q. het aandeel gras in het ruwvoerdeel van het rantsoen. Voor de werkbaarheid zijn binnen dit onderzoek relatief éénvoudige basisrantsoenen gedefinieerd:

- De basisrantsoenen bestaan uit ongeveer $25 \%$ krachtvoer en ongeveer $75 \%$ ruwvoer.

- Het krachtvoerdeel van de rantsoenen bestaat uit eiwitarm mengvoer en bestendig sojaschroot (onderlinge mengverhouding afhankelijk van \% snijmaiskuil in ruwvoerdeel)

- Het ruwvoerdeel van de rantsoenen bestaat uit graskuil en snijmaiskuil in verschillende verhoudingen, $\mathrm{nl} 0 \%, 20 \%, 40 \%, 60 \%$ en $80 \%$ snijmaiskuil in de droge stof. Het gaat daarbij om de gemiddelde gras- en snijmaiskuilen in Nederland (BLGG, 2014). Daarmee zijn 5 basisrantsoenen gedefinieerd.

- De rantsoenen zijn, indien nodig, aangevuld met ureum (ten behoeve van OEB) en/of tarwestro (ten behoeve van structuurwaarde).

Bij het samenstellen van de rantsoenen is niet gestreefd naar een gelijke melkproductie voor alle rantsoenen. Het is weliswaar aantrekkelijk om te onderzoeken welk verschil in methaanemissie bij een bepaalde melkproductie via de rantsoensamenstelling gerealiseerd kan worden, maar het voorliggende onderzoek heeft een andere vraagstelling. Het gaat in dit onderzoek om de vraag of verschillende EF lijsten nodig zijn voor rantsoenen met een verschillende samenstelling. Daarom is de melkproductie niet als leidend genomen, maar volgt de melkproductie uit het gedefinieerde rantsoen en de daarbij horende voeropnamecapaciteit van een gemiddelde NL melkveestapel volgens het Koemodel (Zom, 2014; Zom et al, 2012a; Zom et al, 2012b). Het verschil in de gesimuleerde melkproductie voor de 5 basisrantsoenen is conform de situatie voor dergelijke rantsoenen in de Nederlandse praktijk. De 5 resulterende basisrantsoenen (grondstoffensamenstelling en nutriëntengehalten) zijn in Tabel 2.1 weergegeven, evenals de berekende bijbehorende dierprestaties (per jaar). 
Tabel 2.1 Basisrantsoenen: samenstelling en dierprestaties volgens Koemodel (Zom, 2014)

\begin{tabular}{|c|c|c|c|c|c|}
\hline & $\begin{array}{c}0 \% \\
\text { snijmais }\end{array}$ & $\begin{array}{c}20 \% \\
\text { snijmais }\end{array}$ & $\begin{array}{c}40 \% \\
\text { snijmais }\end{array}$ & $\begin{array}{c}60 \% \\
\text { snijmais }\end{array}$ & $\begin{array}{c}80 \% \\
\text { snijmais }\end{array}$ \\
\hline \multicolumn{6}{|c|}{ Omgerekend naar 365 dagen } \\
\hline FPCM (kg/koe/jaar) & 8137 & 8398 & 8491 & 8623 & 8719 \\
\hline DSO (kg DS/koe/jaar) & 6126 & 6379 & 6492 & 6668 & 6807 \\
\hline DSO (kg DS/koe/dag) & 16.8 & 17.5 & 17.8 & 18.3 & 18.7 \\
\hline \multicolumn{6}{|c|}{ Samenstelling rantsoen ( $\%$ ds) } \\
\hline \multicolumn{6}{|l|}{ Bestendig sojaschroot } \\
\hline Mengvoer laag eiwit NL & 26.7 & 24.6 & 22.0 & 20.8 & 19.9 \\
\hline Mais Silage BLGG & 0.0 & 15.0 & 29.7 & 44.7 & 58.5 \\
\hline Gras Silage BLGG herfst & 22.6 & 17.9 & 12.4 & 7.0 & 1.8 \\
\hline Gras Silage BLGG lente & 27.1 & 21.7 & 15.0 & 8.4 & 2.1 \\
\hline Gras Silage BLGG zomer & 22.6 & 17.9 & 12.4 & 7.0 & 1.8 \\
\hline Ureum & 0.0 & 0 & 0 & 0.4 & 0.6 \\
\hline Tarwe stro & 1.0 & 0.9 & 4.0 & 6.3 & 8.9 \\
\hline$\%$ mengvoer in ds & 26,7 & 26,7 & 26,6 & 26,3 & 26,4 \\
\hline
\end{tabular}

\begin{tabular}{lccccc}
\hline $\begin{array}{l}\text { Rantsoensamenstelling (in g/kg } \\
\text { ds tenzij anders aangegeven) }\end{array}$ & 931 & 948 & 952 & 953 & 954 \\
\hline VEM (eenheidsloos) & 75 & 80 & 85 & 85 & 85 \\
\hline DVE+ & 35 & 22 & 8 & 4 & -3 \\
\hline OEB+ & 176 & 167 & 156 & 152 & 143 \\
\hline Ruw Eiwit & 695 & 707 & 709 & 709 & 708 \\
\hline VOS & 553 & 549 & 535 & 523 & 511 \\
\hline FOSp+ & 223 & 229 & 240 & 249 & 259 \\
\hline Ruwe celstof & 101 & 89 & 77 & 64 & 53 \\
\hline Ruw as & 80 & 80 & 80 & 79 & 78 \\
\hline VCOS (\%) & 83 & 73 & 61 & 49 & 37 \\
\hline Suiker & 26 & 82 & 137 & 194 & 247 \\
\hline Zetmeel & 2,22 & 2,17 & 2,17 & 2,14 & 2,13 \\
\hline Structuurwaarde (SW eenheid) & 451 & 427 & 409 & 391 & 376 \\
\hline NDF & 255 & 241 & 233 & 224 & 217 \\
\hline ADF & 24 & 23 & 23 & 23 & 24 \\
\hline ADL & 40 & 39 & 37 & 35 & 34 \\
\hline Ruw vet & & & & \\
\hline
\end{tabular}




\subsubsection{Impact EF lijsten op berekende methaanemissie}

Voor de rantsoenen $0 \%, 40 \%$ en $80 \%$ snijmaissilage is met het model van Bannink et al, 2011 voor 8 representatieve veevoedergrondstoffen de methaanemissie berekend (Figuur 2.1). Het betreft grondstoffen uit de groep granen (i.c. tarwe, gerst en mais; zetmeelrijk), reststroom energiegewassen (i.c. bietenpulp; suiker en pectinerijk), reststroom eiwitgewassen (i.c. sojahullen; vezelrijk) en reststroom oliehoudende zaden (i.c. palmpitschilfers en raapzaadschroot; eiwitrijk). Voor palmpitschilfers zijn 2 varianten meegenomen om de variatie in EF binnen een grondstofsoort (verschil in samenstelling, in dit geval in ruwe celstof (RC) -gehalte) te kunnen vergelijken met de variatie in EF tussen grondstofsoorten.

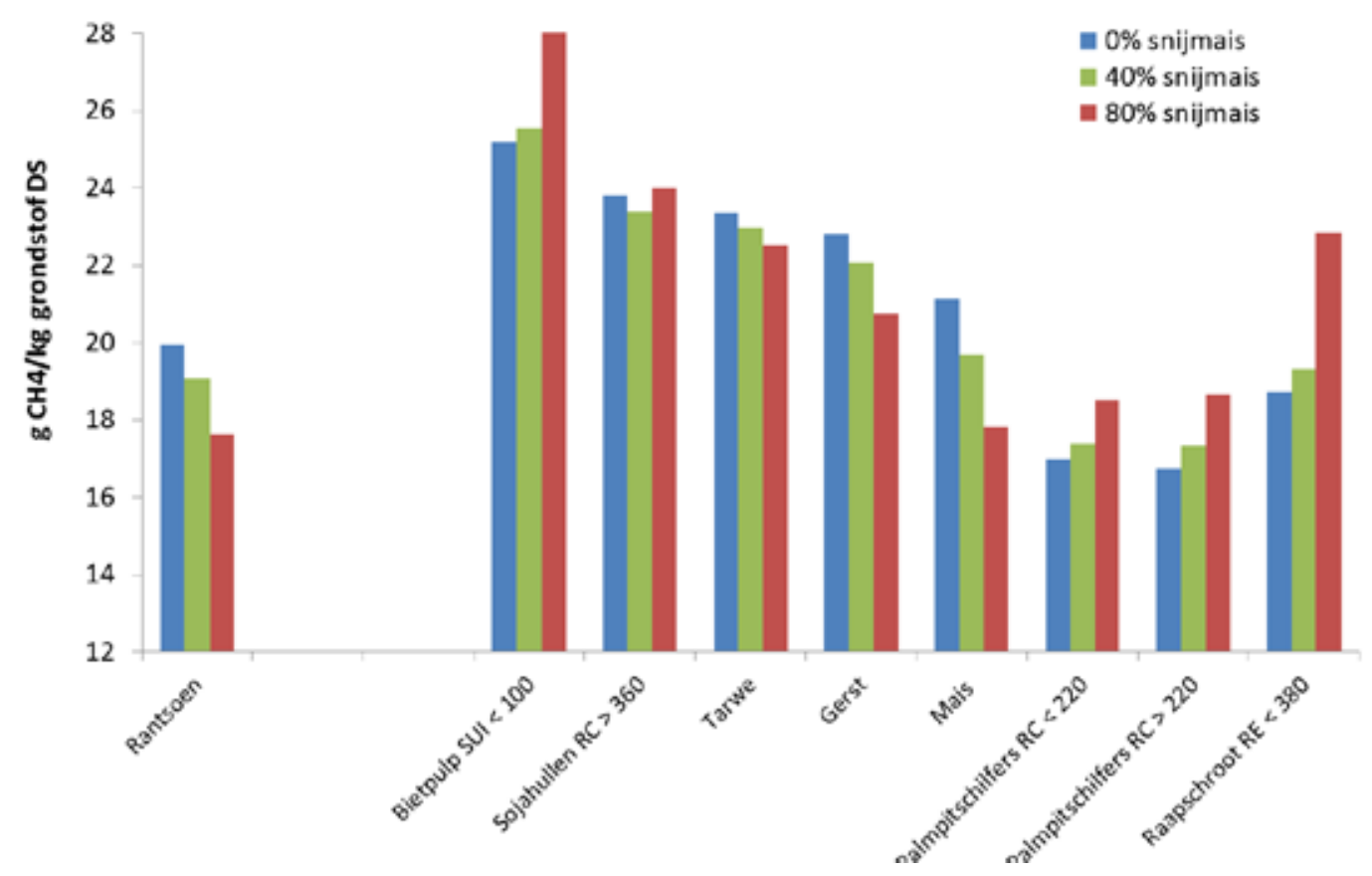

Figuur 2.1 Invloed van rantsoensamenstelling op de methaanemissie ( $\mathrm{g} / \mathrm{kg} \mathrm{ds}$ ) van een enkelvoudige grondstof

Uit Figuur 2.1 blijkt dat de rantsoensamenstelling (het aandeel snijmaiskuil in ruwvoer) een grote invloed had op de voor de grondstof berekende EF (in g methaan per kg DS grondstof ). De EF voor de beide uiterste rantsoenen (i.c. $0 \%$ en $80 \%$ snijmaiskuil in ruwvoerdeel van het rantsoen) verschilden gemiddeld ongeveer $11 \%$, met een maximum verschil in EF waarde tussen $0 \%$ snijmaiskuil en $80 \%$ snijmaiskuil van $22 \%$ en een minimum van $3 \%$. Het verschil in EF tussen $0 \%$ en $40 \%$ snijmaiskuil ondersteunt die conclusie met een gemiddeld verschil van ca. 4,5\% (maximum $9 \%$ en minimum $1 \%$ ), waarmee na afronding eveneens het gestelde criterium van $5 \%$ werd gehaald (zie voor criterium paragraaf 2.2.2 Methodiek ad 2). Op basis van deze uitkomsten adviseerde het begeleidingsteam om de nieuwe rekenregels voor de KringloopWijzer te baseren op meerdere EF lijsten.

\subsubsection{Impact rantsoensamenstelling op EF van graskuil en snijmaiskuil}

De ruwvoeders graskuil en snijmaiskuil hebben een groot aandeel in de droge stof van het rantsoen. Ook voor deze producten is de gevolgde methodiek met $5 \%$ uitwisseling op basis van droge stof een correcte aanpak om de methaanemissies ( $\mathrm{g} / \mathrm{kg} \mathrm{ds}$ ) te berekenen. Figuur $2.2 \mathrm{geeft}$ daarvan de resultaten. 


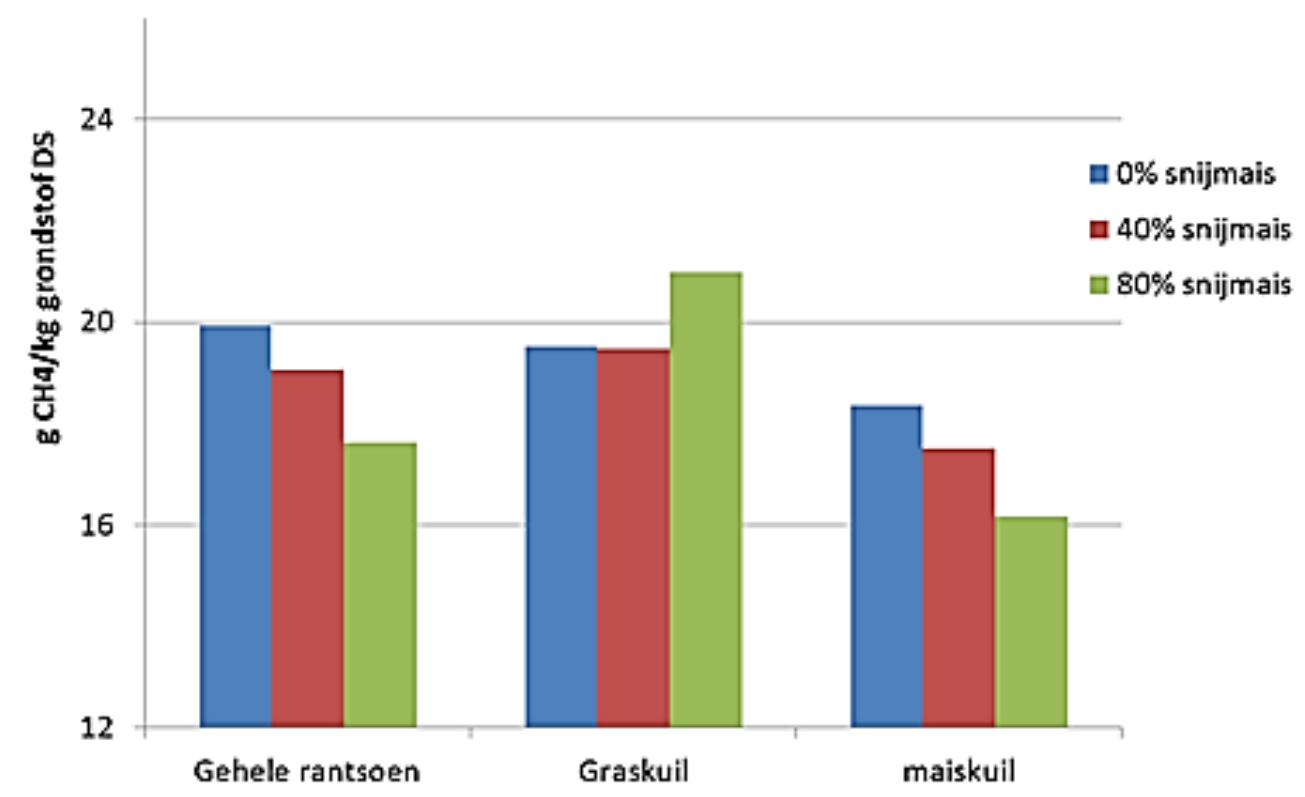

Figuur 2.2 Invloed van rantsoensamenstelling op de methaanemissie ( $\mathrm{g} / \mathrm{kg} \mathrm{ds}$ ) van het gehele rantsoen en van de ruwvoeders graskuil en snijmaiskuil

Uit Figuur 2.2 blijkt dat er verschil is tussen de methaanemissie ( $\mathrm{g} / \mathrm{kg} \mathrm{ds}$ ) van rantsoenen met een verschillend aandeel snijmaiskuil in het ruwvoerdeel van het rantsoen. Dat geldt niet alleen voor het gehele rantsoen en enkelvoudige veevoedergrondstoffen (paragraaf 2.3.2), maar ook voor de ruwvoeders graskuil en snijmaiskuil. De berekende verschillen in EF als gevolg van de rantsoensamenstelling (i.c. het \% snijmaiskuil in het ruwvoerdeel) is voor deze ruwvoeders van dezelfde orde van grootte als die voor de enkelvoudige grondstoffen in Figuur 2.1.

Opvallend in Figuur 2.2 is de schijnbaar afwijkende waarde voor graskuil. In tegenstelling tot de algemene trend van een dalende EF waarde voor het gehele rantsoen en voor maiskuil met een toename van het aandeel maiskuil in ruwvoer, bleef de EF-waarde voor graskuil gelijk (bij een aandeel van $40 \%$ maiskuil) of nam zelfs toe (bij aandeel $80 \%$ maiskuil). Een zelfde patroon als weergegeven voor graskuil in Figuur 2.2 werd doorgaans verkregen voor suiker en pectinerijke producten (zoals vinasse, bietenpulp en cichorei), voor zetmeelrijke producten waarvan het zetmeel snel fermenteerbaar is (zoals aardappelstoomschillen), en voor eiwitrijke producten (zoals kaaswei en raapschroot). Zetmeelrijke producten waarvan het zetmeel relatief bestendig is (zoals maiszetmeel of aardappelzetmeel) werd doorgaans een patroon verkregen zoals voor maiskuil in Figuur 2.2.

De achtergronden van dergelijke verschillen in respons in EF-waarde van grondstoffen met een stijging van het aandeel maiskuil in ruwvoer zijn gelegen in de chemische samenstelling van de producten (met een onderscheid tussen suiker en zetmeel die volgens het model door de amylolytische micro-organismen verbruikt worden, en de celwandbestanddelen of NDF die volgens het model door de fibrolytische micro-organismen verbruikt worden). Een andere samenstelling van de rantsoen ds en andere afbraakeigenschappen van de chemische bestanddelen in die ds (suikers, zetmeel, NDF, eiwit) maken dat $5 \%$ uitwisseling van die ds met een specifieke grondstof een andere uitwerking heeft op de berekende verandering in methaanemissie. Niet alleen de mate van verandering, ook de richting van verandering kan anders uitvallen bij verschillende rantsoensamenstellingen. Om die reden hoeven modeluitkomsten niet een proportionele verandering te laten zien aan verandering van het aandeel maiskuil in het ruwvoer. Dit is in principe wel het geval met gebruik van additionele systemen als het VEM-systeem en DVE/OEB-systeem waarbij de grondstoffen een vaste voederwaarde hebben.

\section{Resultaat EF lijsten}

Gezien het resultaat van de voorstudie met 8 veevoedergrondstoffen, zijn voor de basisrantsoenen $0 \%, 40 \%$ en $80 \%$ snijmaiskuil in het ruwvoerdeel aparte EF lijsten aangemaakt (zie Bijlage 1). Uit Bijlage 1 blijkt dat de conclusies op basis van 8 grondstoffen (Figuur 2.1) illustratief zijn voor de uitkomsten van de gehele lijst van grondstoffen. Het verschil in methaanemissie tussen de beide 
uiterste basisrantsoenen $0 \%$ en $80 \%$ snijmaiskuil (respectievelijk 19.94 en $17.64 \mathrm{~g} \mathrm{CH}_{4} / \mathrm{kg} \mathrm{DS}$ ) bedraagt ongeveer $12 \%$. Voor alle grondstoffen in de EF lijst $0 \%$ snijmais was de gemiddelde EF van $19.16 \pm 6.46 \mathrm{~g} \mathrm{CH}_{4} / \mathrm{kg}$ DS en voor $80 \%$ snijmais was dat $19.61 \pm 6.37 \mathrm{~g} \mathrm{CH}_{4} / \mathrm{kg}$ DS. Voor de zetmeelrijke producten neemt de methaanemissie ( $\mathrm{g} / \mathrm{kg} \mathrm{DS}$ ) af met toenemende \% snijmaiskuil in het rantsoen en voor de suiker-, vezel- en eiwitrijke producten neemt de methaanemissie dan toe.

\subsubsection{Interpolatie van EF lijsten}

De gekozen insteek is om, waar mogelijk, met eenvoudige rekenregels te werken. Voor het gebruik van de EF lijsten is daarom onderzocht of de methaanemissie ( $\mathrm{g} / \mathrm{kg} \mathrm{DS}$ ) voor alle basisrantsoenen goed kan worden geschat via interpolatie van de beide EF lijsten voor de uiterste rantsoenen $(0 \%$ en $80 \%$ snijmaiskuil). Controle of deze interpolatie resulteerde in correcte methaanemissies is gedaan door voor alle 5 basisrantsoenen $(0 \%, 20 \%, 40 \%, 60 \%$ en $80 \%$ snijmaiskuil) de met het Tier 3 model (Bannink et al, 2011) berekende methaanemissie te vergelijken met de methaanemissie zoals berekend met de geïnterpoleerde EF waarden. De resultaten zijn grafisch weergegeven in Figuur 2.3.

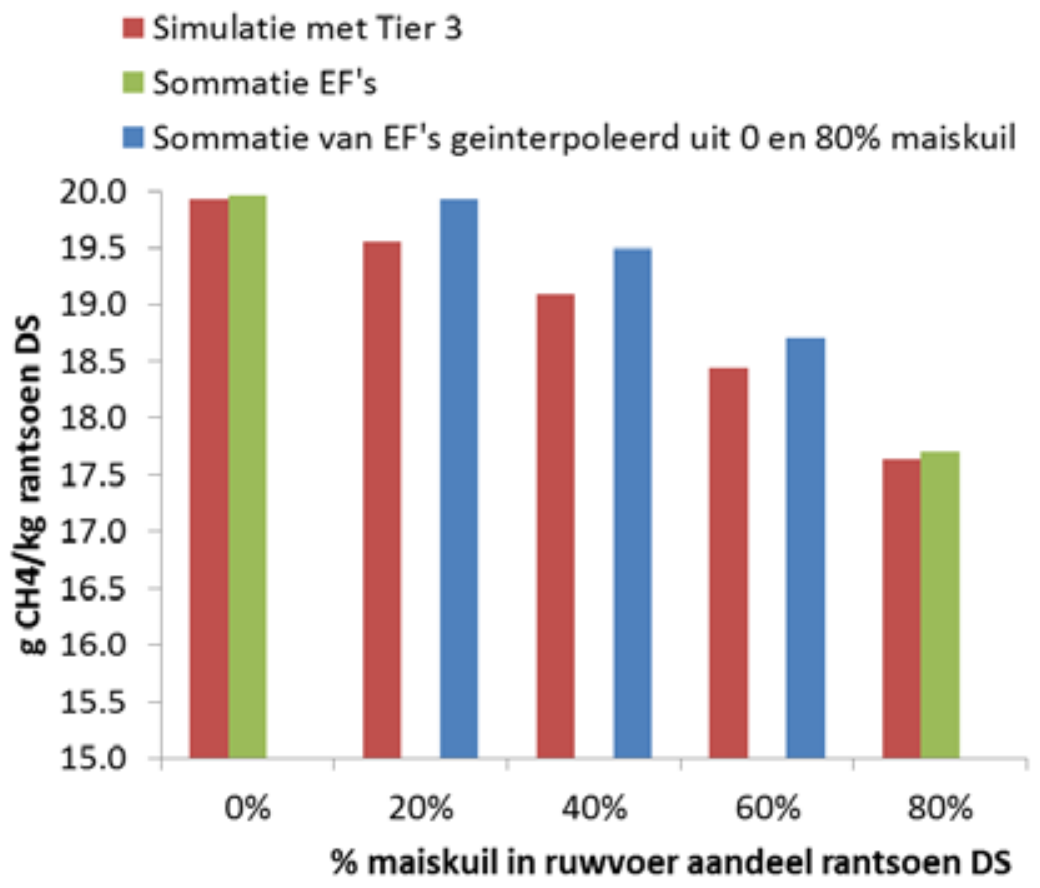

Figuur 2.3 Methaanemissie voor de 5 basisrantsoenen ( $\mathrm{g} \mathrm{CH}_{4}$ per $\mathrm{kg} \mathrm{DS}$ ) gesimuleerd volgens de Tier 3 benadering en berekend (door sommatie) op basis van de EF-lijsten voor de rantsoenen met $0 \%$ en $80 \%$ snijmaissilage in het ruwvoer. De groene balken geven de basis EF-lijsten weer en de blauwe balken geven interpolaties weer.

Conclusies:

- De berekende methaanemissie (g/kg DS) op basis van EF-lijsten is voor de basisrantsoenen $0 \%$ en $80 \%$ snijmaiskuil gelijk aan die berekend met het Tier 3 model.

- De berekende methaanemissie (g/kg DS) op basis van de geïnterpoleerde EF waarden laat voor de basisrantsoenen $20 \%, 40 \%$ en $60 \%$ snijmaiskuil een afwijking naar boven zien van ongeveer $5 \%$ voor het basisrantsoen ' $20 \%$ snijmaiskuil' afnemend tot ongeveer $3 \%$ voor het basisrantsoen '60\% maiskuil snijmaiskuil'.

- De berekende methaanemissies (g/kg DS) op basis van geïnterpoleerde EF waarden volgen de trend zoals berekend met het Tier 3 model.

- Het verschil van maximaal 5\% tussen de methaanemissie (g/kg DS) op basis van EF-lijsten en die berekend met het Tier 3 model is weliswaar de algemeen geaccepteerde onnauwkeurigheid, maar deze onnauwkeurigheid kan worden weggenomen door toevoeging van een derde EF lijst voor het gemiddelde rantsoen van $40 \%$ snijmaiskuil. 
Op basis van deze conclusies is besloten om de interpolatie uit te voeren op basis van 3 EF lijsten $(0 \%, 40 \%$ en $80 \%)$. Dit om de lichte overschatting op basis van interpolatie voor het middengebied van de range voor het aandeel snijmais in ruwvoer weg te nemen. Naast de EF-lijsten voor $0 \%$ snijmais en $80 \%$ snijmais werd ook de EF-lijst voor $40 \%$ snijmais in het ruwvoer gebruikt voor interpolatie. Daarmee is het mogelijk om voor rantsoenen met een aandeel snijmais tussen $0 \%$ en $40 \%$ te interpoleren met de EF-lijsten '0\% snijmais' en '40\% snijmais' en voor rantsoenen met een aandeel snijmais tussen $40 \%$ en $80 \%$ te interpoleren met de EF-lijsten ' $40 \%$ snijmais' en '80\% snijmais'. Figuur 2.4 toont de uitkomsten van de interpolatie voor de rantsoenen met een aandeel snijmais van $20 \%$ en $60 \%$.

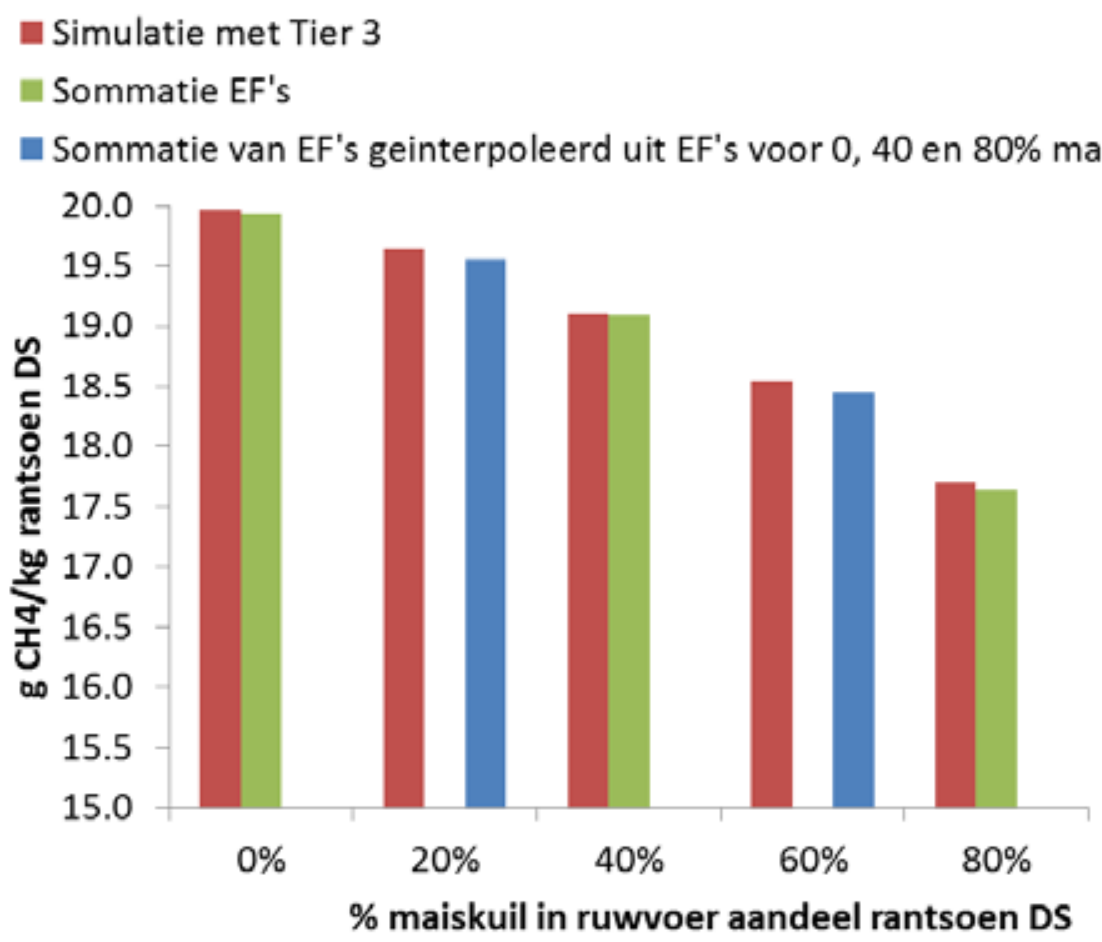

Figuur 2.4 Methaanemissie voor de 5 basisrantsoenen ( $\mathrm{g} \mathrm{CH}_{4}$ per $\mathrm{kg} \mathrm{DS}$ ) gesimuleerd volgens de Tier 3 benadering en berekend (door sommatie) op basis van de EF-lijsten voor de rantsoenen met $0 \%, 40 \%$ en $80 \%$ snijmaissilage in het ruwvoer. De groene balken geven de basis EF-lijsten weer en de blauwe balken geven interpolaties weer.

Uit Figuur 2.4 blijkt dat op basis van EF-lijsten voor de rantsoenen met $0 \%, 40 \%$ en $80 \%$ snijmais in het ruwvoer, de geïnterpoleerde methaanemissies nagenoeg overeen komen met de methaanemissies zoals berekend met de Tier 3 benadering. De eerder geconstateerde afwijkingen voor $20 \%$ en $60 \%$ snijmais bij gebruik van 2 basis EF-lijsten (Figuur 2.3) zijn verdwenen in Figuur 2.4. Er resteert een verschil van minder dan $0,1 \%$ tussen de methaanemissie ( $\mathrm{g} / \mathrm{kg} \mathrm{DS}$ ) berekend met de Tier 3 benadering en de methaanemissie berekend op basis van interpolatie met de EF-lijsten voor de rantsoenen met $0 \%, 40 \%$ en $80 \%$ snijmaissilage in ruwvoer.

\subsubsection{Jongvee}

De KringLoopWijzer geeft uitsluitend info over het veestapel rantsoen, er wordt geen onderscheid gemaakt naar melkvee en jongvee. Toch mag verwacht worden dat voor jongvee andere EF gelden dan voor melkvee door:

- ander rantsoen

- $\quad$ ander kwaliteit ruwvoeders

- ander voeropnameniveau 
Uit een rapport van Gerrits et al (2014) blijkt dat ook voor jongvee de EF samenhangt met de samenstelling van het rantsoen. Zodra kalveren ruwvoer krijgen stijgt de EF als \% van de bruto energieopname. Kalveren die redelijk wat ruwvoer krijgen hebben een EF die overeenkomt met $6.5 \%$ van de bruto energieopname. Dat is gelijk aan de aanname in de Tier 2 benadering voor rundvee volgens IPCC. Dit betekent dat voor het wat oudere jongvee (dat ruwvoer krijgt) op dezelfde manier gerekend kan worden als voor melkvee. Echter, voor de Nederlandse omstandigheden is via Tier 3 voor melkvee vastgesteld dat deze waarde niet $6.5 \%$, maar $6.0 \%$ van de bruto energieopname is. De vraag is dan ook of voor jongvee gehouden onder Nederlandse omstandigheden ook een lagere EF (dan 6.5\%) moet worden aangehouden. Er is vooralsnog geen informatie beschikbaar waarmee deze vraag beantwoord kan worden.

Om pragmatische redenen kunnen de EF-lijsten voor melkvee ook voor jongvee gebruikt worden, omdat er dan op veestapelniveau met het gemiddelde rantsoen gerekend kan worden. Dat sluit aan bij de rekenwijze en beschikbare informatie in de KringloopWijzer en wordt de methaanemissie van alle op het bedrijf vervoederde ruwvoeders en krachtvoeders op dezelfde wijze ingerekend. Voor het jongere jongvee wordt dan in principe een overschattingsfout gemaakt. Voor die dieren houdt de eerder aangehaalde notitie van Gerrits et al (2014) namelijk een zeer lage waarde van $1.7 \%$ aan op basis van een bijdrage met $0.3 \%$ vanuit kalvermelk en $5.5 \%$ vanuit ruw- $\&$ krachtvoer. Indien het aandeel krachtvoer erg hoog is dan daalt de methaanemissie naar $4 \%$ van de bruto energieopname.

\section{$2.4 \quad$ Conclusies}

De enterische methaanemissie van melkvee kan goed geschat worden op basis van rantsoendifferentiatie naar het aandeel snijmais in het ruwvoerdeel van het rantsoen. Daarbij moet gebruikt gemaakt worden van interpolatie met 3 EF-lijsten (voor rantsoenen met 0\%, 40\% en $80 \%$ snijmais in het ruwvoer). Deze benadering voldoet ook voor het oudere jongvee dat ruwvoer opneemt. Daarmee past het bij de benadering van de KringloopWijzer om voor rantsoenen op veestapelniveau te rekenen. $\mathrm{Er}$ is bij het berekenen van de $\mathrm{CH}_{4}$ emissies op veestapelniveau wellicht een correctie (vermindering) nodig voor jonge kalveren met een rantsoen dat slechts een gering aandeel ruwvoer bevat. 


\section{Methaanemissie en voeropnameniveau}

\subsection{Algemeen}

Het functioneren van de pens en daarmee de enterische methaanemissie wordt in principe door 3 belangrijke kenmerken bepaald: rantsoensamenstelling, opnameniveau (en als afspiegeling daarvan de melkproductie) en de kwaliteit van het ruwvoer. Allemaal kenmerken waarvoor de informatie via de KringloopWijzer beschikbaar is. Toch ligt in de in paragraaf 3.3.1 beschreven werkwijze de focus op de rantsoensamenstelling. De reden is dat de effecten van opnameniveau ( $\&$ melkproductie) en van ruwvoerkwaliteit aanvullend (additief) op de effecten van de rantsoensamenstelling kunnen worden ingebracht voor verdere detaillering en verbetering van de nauwkeurigheid van de berekeningen.

\subsection{Materiaal en methoden}

\subsubsection{Aanpak}

Voor de twee meest extreme rantsoenen ( $0 \%$ en $80 \%$ snijmaissilage in ruwvoer) is de methaanemissie berekent bij een variatie van de voeropname van 14 tot $24 \mathrm{~kg}$ ds per dier per dag. Op deze wijze wordt inzicht verkregen in de mate waarin de volgens de Tier 3 benadering gesimuleerde methaanemissie varieert met de voeropnameniveau.

\subsubsection{Rekenmethodiek}

De Tier 3 benadering is toegepast om het effect van voeropname op methaanemissie te simuleren. Deze benadering houdt zowel rekening met verandering van de passagesnelheid met voeropnameniveau, als met de verandering van de zuurgraad in de pens en het profiel van vluchtige vetzuren $^{2}$ dat gevormd wordt.

\subsubsection{Data}

Er zijn geen verdere data nodig voor deze berekeningen. Met de keuze voor een range van voeropnameniveaus van 14 tot 24 wordt de variatie in voeropnameniveau van een veestapel die met de KringLoopWijzer wordt doorgerekend ruimschoots gedekt. De berekeningen zijn uitgevoerd voor de rantsoenen met $0 \%$ en $80 \%$ snijmaissilage in het ruwvoer, waarbij alle modelinvoer gelijk werd gehouden behalve de voeropname.

\subsection{Resultaten}

Figuur 3.1 toont de resultaten van deze simulaties. De gesimuleerde methaanemissie nam per $\mathrm{kg}$ extra ds-opname per dag gemiddeld met $0.20 \mathrm{~g}$ methaan $/ \mathrm{kg}$ ds af voor het rantsoen met $0 \%$ snijmaissilage in ruwvoer, en met $0.22 \mathrm{~g}$ methaan/ $\mathrm{kg}$ ds af voor het rantsoen met $80 \%$ snijmaissilage in ruwvoer. Deze afname nam continu in grootte af met een toenemende voeropnameniveau van 14

\footnotetext{
${ }^{2}$ Het profiel van de gevormde vluchtige vetzuren heeft een directe invloed op de gesimuleerde hoeveelheid methaan omdat een profielverschuiving bij een zuurdere pens relatief meer propionzuur en minder waterstofproductie geeft, met als gevolg minder methaan.
} 
tot $24 \mathrm{~kg}$ ds per dier per dag, vanaf 0.23 tot $0.16 \mathrm{~g}$ methaan $/ \mathrm{kg}$ ds met $0 \%$ snijmaissilage en vanaf 0.26 tot $0.18 \mathrm{~g}$ methaan $/ \mathrm{kg}$ ds.

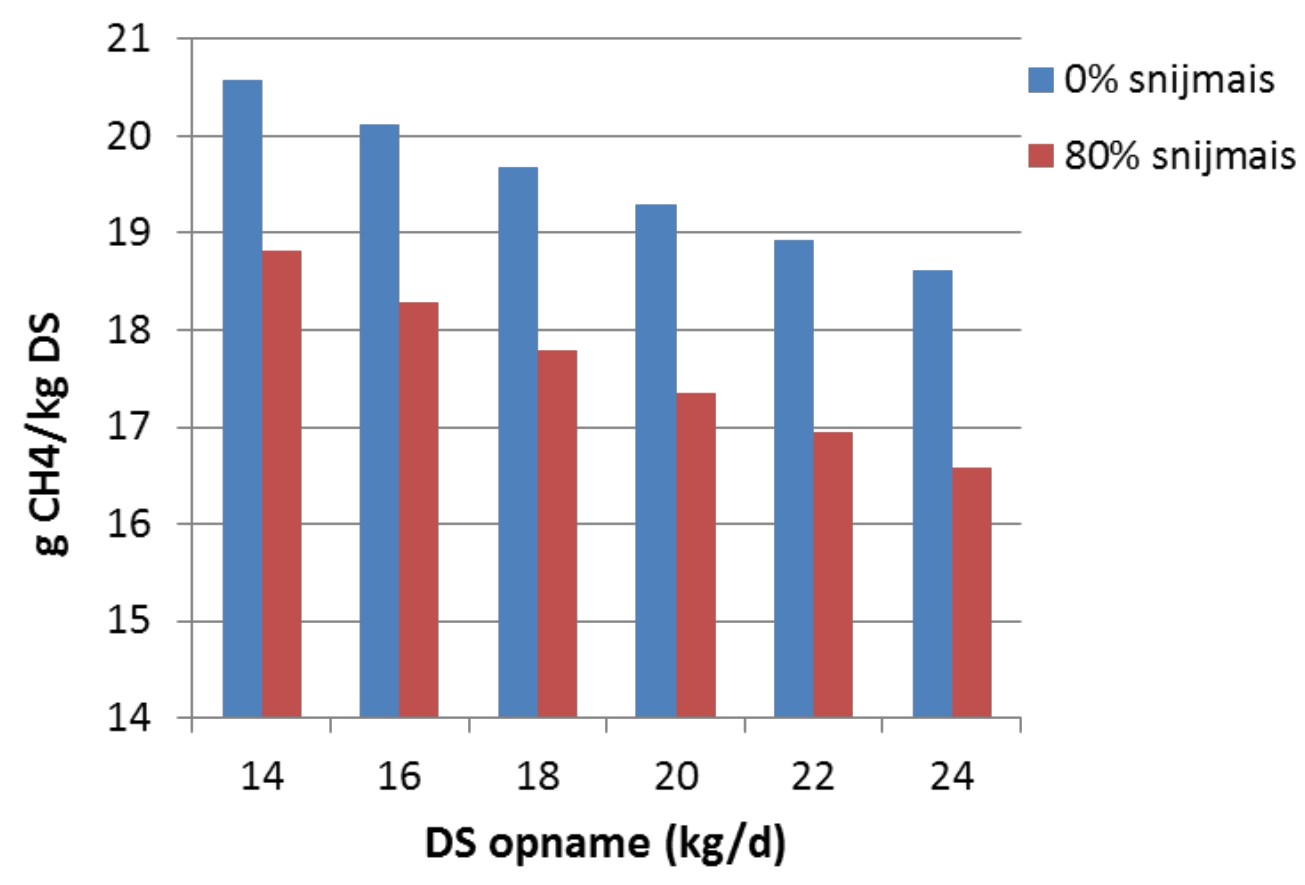

Figuur 3.1. Het effect van voeropname ( $\mathrm{kg}$ droge stof per dier per dag) op de methaanemissie ( $\mathrm{g} / \mathrm{kg}$ droge stof), gesimuleerd met de Tier 3 benadering bij een gelijkblijvend rantsoen.

\subsection{Conclusies}

De enterische methaanemissie berekend via het gebruik van EF-lijsten op basis van het snijmaisaandeel in het ruwvoer, wint aan nauwkeurigheid wanneer het effect van voeropnameniveau wordt meegerekend. Tussen rantsoenen met een extreem verschil in aandeel snijmais in het ruwvoerdeel ( $0 \%$ en $80 \%$ snijmais), is een klein verschil van $0,02 \mathrm{~g}$ methaan $/ \mathrm{kg}$ ds (ca. $10 \%$ ) geconstateerd in het effect van voeropnameniveau op de methaanemissie per $\mathrm{kg}$ droge stof. Bij een stijgende voeropname (van 14 tot $24 \mathrm{~kg}$ ds/dag) nam het effect van het voeropnameniveau op de methaanemissie per $\mathrm{kg}$ droge stof af. Ook die afname verschilde gemiddeld nauwelijks tussen de rantsoenen met $0 \%$ dan wel $80 \%$ snijmaissilage. Rondom de gemiddelde droge stof opname van melkvee in Nederland (18,5 kg ds per dier per dag) zal de voeropname voor veestapels veel minder verschillen dan de doorgerekende range in voeropnameniveau van 14 tot $24 \mathrm{~kg}$ ds per dag. Voor gebruik in de KringloopWijzer volstaat het aanhouden van een gemiddelde verandering van de berekende methaanemissie per $\mathrm{kg}$ ds (op basis van EF-lijsten) van $0.21 \mathrm{~g}$ methaan per $\mathrm{kg}$ ds ten opzichte van de gemiddelde voeropname van $18,5 \mathrm{~kg}$ ds per dier per dag. 


\section{$4 \quad$ Methaanemissie en ruwvoerkwaliteit}

\subsection{Algemeen}

Het melkveerantsoen bestaat gemiddeld voor driekwart uit ruwvoer. Het is om die reden belangrijk om het effect van ruwvoerkwaliteit op de methaanemissie mee te nemen. Er zijn echter weinig metingen gedaan aan het effect van ruwvoerkwaliteit op de methaanemissie en bovendien verschillen de inzichten in de literatuur. Uit recent experimenteel onderzoek in EmissieArm Veevoer met als specifiek doel om het effect van graslandmanagement in vivo in melkvee te testen, kwam duidelijk naar voren dat met name het maai/oogstmoment een grote invloed heeft op de hoeveelheid methaan per $\mathrm{kg}$ droge stof gras. De betreffende experimenten zijn niet geschikt om effecten van $\mathrm{N}$-bemestingsniveau te onderzoeken, omdat het aantal weken hergroei gelijk werd gehouden voor laag en hoog-bemest grasland. Deze keuze werd gemaakt vanwege de proefopzet, maar verschilt van de praktijk omdat bij hoge bemesting het gras sneller groeit en eerder geoogst zal worden. In de praktijk zal een hogere Nbemesting leiden tot een vroegere oogst van het gras vergeleken met lage $\mathrm{N}$-bemesting. Met andere woorden, in de praktijk is bij een hogere $\mathrm{N}$-bemesting een jonger gras en een lagere methaanemissie per $\mathrm{kg}$ ds voor dat gras te verwachten. Bannink et al (2010) simuleerden eerder al met de Tier 3 benadering dat een forse invloed te verwachten is van $\mathrm{N}$-bemesting en oogstmoment (zwaarte snede) op de methaanemissie per $\mathrm{kg}$ droge stof gras. Recent experimenteel onderzoek in het programma EmissieArm Veevoer heeft deze verschillen in methaanemissie als gevolg van verschillen in gras- en snijmaiskwaliteit bevestigd (Warner et al, 2015 en 2016; Hatew et al, 2015 en 2016).

\subsection{Materiaal en methoden}

\subsubsection{Aanpak}

Voor de in Nederland belangrijkste ruwvoeders (vers gras, graskuil en maiskuil) moeten de belangrijkste effecten van de (kuil)kwaliteit meegenomen worden bij de berekening van de enterische methaanemissie per kg droge stof. Echter, voor het toevoegen van de kwaliteit van het ruwvoer wordt doorrekening belemmerd door het ontbreken van goede relaties (regressieverbanden) tussen de te bepalen EF enerzijds en de chemische samenstelling en voederwaarde anderzijds. In het programma Emissiearm Veevoer wordt het effect van graskwaliteit op methaanemissie onderzocht, zowel experimenteel als modelmatig, maar is het afleiden van praktisch hanteerbare regressieverbanden voor het schatten van de methaanemissie in afhankelijkheid van chemische samenstelling en verteerbaarheid geen onderwerp van onderzoek. Daarvoor zouden grootschalig modelsimulaties uitgevoerd moeten worden met variatie in het gehalte aan suiker, celwand, ruw eiwit, ammoniak, nitraat, organische zuren, vet en as (zoals aangegeven door BLGG analyses), gevolgd door regressie van de gesimuleerde methaanemissie op deze kenmerken. Deze resultaten komen in 2015 niet beschikbaar vanuit EmissieArmVeevoer voor de KringloopWijzer. Om die reden is in het voorliggende project voor de belangrijkste ruwvoeders in principe de bovenstaande aanpak gevolgd, maar dan aangepast aan de summiere beschikbare gegevens.

\subsubsection{Rekenmethodiek en data}

De Tier 3 benadering werd gebruikt om het effect van graskwaliteit op de enterische methaanemissie per kg droge stof te kwantificeren.

Voor graskuil is slechts een beperkte dataset beschikbaar om het effect van kwaliteit op de methaanemissie af te leiden. De informatie uit die beperkte dataset is gecombineerd met eerdere simulatiegegevens (Bannink et al, 2010) en de parallellen die te trekken zijn met recente meetgegevens. Op die wijze is voor enkele standaard graskuilkwaliteiten en oogstmomenten een inschatting gemaakt van de enterische methaanemissie per kg droge stof. Met name het aantal weken 
hergroei (ouderdomsstadium van het gras) blijkt een sterk bepalende factor te zijn voor de methaanemissie. Voor snijmaissilage zijn recente meetgegevens leidend geweest voor de kwantificering van het effect van kwaliteit op de methaanemissie.

\subsection{Resultaten}

\subsubsection{Vers gras}

Het effect van de vers graskwaliteit op de methaanemissie werd experimenteel onderzocht in EmissieArm Veevoer en werd doorgerekend met de Tier 3 benadering op basis van waarnemingen in experimenten. De Tier 3 benadering kan een deel van de waargenomen variatie reproduceren (Bannink et al, 2016) waarbij het beeld naar voren komt dat naast voeropnameniveau ook de samenstelling en afbraakeigenschappen van gras meewegen in de hoeveelheid methaan die ontstaat. Dit is in overeenstemming met eerdere simulatieresultaten van Bannink et al (2010). Op basis van die resultaten werd reeds in het project FeedPrint een inschatting gemaakt van de variatie in methaanemissie per $\mathrm{kg}$ droge stof vers gras voor de verschillende kwaliteiten en oogstmomenten die in de CVB tabel vermeld worden. De impact van kwaliteit en oogstmoment bleek gerelateerd te zijn aan de opbrengst en voor een hoge en lage opbrengst aan vers gras werd respectievelijk 23,24 en $19,24 \mathrm{~g}$ methaan/ $\mathrm{kg}$ ds vers gras geschat. In hetzelfde onderzoek werd voor grashooi 20,24 g methaan/kg ds geschat en voor graskuil met een opbrengst van 2,0, 3,0 (of 3,5) en 4,0 (of 5,0 in mei) ton ds per hectare werd respectievelijk 18,24, 20,24 en 22,24 g methaan/kg ds graskuil geschat.

\subsubsection{Ingekuild gras}

Uit het recente experimentele onderzoek in EmissieArm Veevoer werd voor in totaal 10 verschillende graskuilen 14 onafhankelijke waarnemingen van de methaanemissie verkregen. Met behulp van lineaire regressie werd voor 10 onafhankelijke waarnemingen voor graskuil onderzocht of de methaanemissie in $\mathrm{g} / \mathrm{kg}$ ds totaal rantsoen toe- dan wel afneemt bij een toename van het gehalte van voerkenmerken (Tabel 4.1). De rantsoenen bevatten $70 \%$ of $80 \%$ aan graskuil op ds basis. De tabel geeft de richtingscoëfficiënt voor de verandering in methaanemissie in g methaan/ $\mathrm{kg}$ ds rantsoen per aangegeven verandering in een voerkenmerk, en het deel van de variatie in gemeten methaanemissie dat verklaard wordt met deze lineaire regressies $\left(R^{2}\right)$.

Tabel 4.1 Relatie tussen een toename van enkele voerkenmerken en de methaanemissie voor graskuilrantsoenen (in $\mathrm{g} / \mathrm{kg}$ rantsoen $\mathrm{ds}$ ).

\begin{tabular}{|c|c|c|}
\hline $\begin{array}{l}\text { Toename in aangegeven } \\
\text { voerkenmerk voor het totale } \\
\text { rantsoen }\end{array}$ & $\begin{array}{c}\text { Verandering methaan } \\
\text { (g/ kg ds rantsoen) } \\
\text { aangegeven toename } \\
\text { voerkenmerk }\end{array}$ & $\mathbf{R}^{2}$ \\
\hline $100 \mathrm{~g} \mathrm{NDF} / \mathrm{kg} \mathrm{ds}$ & 2.2 & 0.72 \\
\hline $100 \mathrm{~g}$ suiker $/ \mathrm{kg}$ ds & 1.4 & 0.12 \\
\hline $100 \mathrm{~g}$ ruw eiwit/ kg ds & -2.1 & 0.68 \\
\hline $100 \mathrm{~g} \mathrm{OEB} / \mathrm{kg} \mathrm{ds}$ & -2.5 & 0.68 \\
\hline $100 \mathrm{~g} \mathrm{DVE} / \mathrm{kg}$ ds & -7.9 & 0.39 \\
\hline $100 \mathrm{VEM} / \mathrm{kg} \mathrm{ds}$ & -1.8 & 0.56 \\
\hline $10 \mathrm{~g}$ ruw vet $/ \mathrm{kg}$ ds & -1.8 & 0.63 \\
\hline $10 \%$ VCOS & -1.1 & 0.07 \\
\hline
\end{tabular}


Uit tabel 4.1 blijkt dat voor twee kenmerken (NDF en suiker) de methaanemissie toeneemt bij een toename van het gehalte van dat kenmerk. Voor de overige voerkenmerken (VEM, de in vivo waargenomen VCOS, DVE, OEB, ruw vet, en ruw eiwit) blijkt de methaanemissie af te nemen bij een toename van het gehalte. Deze relaties stemmen overeen met de aannames die in de Tier 3 benadering gemaakt worden, en de algemene uitkomsten van het experimentele onderzoek in EmissieArm Veevoer.

Oppassen bij vertaling van experiment naar algemene toepassing

De range aan waarden voor de voerkenmerken in tabel 4.1 is volledig bepaald door de gekozen proefopzet in de experimenten in het project EmissieArm Veevoer.

Daarbij is variatie aangelegd in het $\mathrm{N}$ bemestingsniveau van grasland, in het aantal dagen hergroei (ouderdom of groeistadium van het geoogste gras) en in opnameniveau (middels verschil in lactatiestadium van het melkvee). Echter, ook andere factoren kunnen invloed uitoefenen op deze voerkenmerken van gras (bijvoorbeeld vanwege een ander aandeel gras in het rantsoen, of bij combinatie met bijvoeding als maiskuil) en dus is enige terughoudendheid geboden bij het algemeen toepassen van de informatie uit tabel 4.1 .

De experimentele rantsoenen bevatten $70 \%$ of $80 \%$ graskuil (gewogen gemiddelde aandeel $74 \%$ ), en onder aanname dat de gemeten veranderingen in methaanemissie volledig aan het gevarieerde grasproduct zijn toe te schrijven, dienen de verandering in methaanemissie aangegeven in tabel 4.1 gecorrigeerd te worden naar $100 \%$ grasproduct vermenigvuldigd te worden met 1,35 (tabel 4.2).

Tabel 4.2 Relatie tussen een toename van voerkenmerken en de methaanemissie voor graskuilrantsoenen (gecorrigeerd naar $\mathrm{g} / \mathrm{kg}$ ds graskuil).

\begin{tabular}{|c|c|c|}
\hline \multirow[t]{2}{*}{$\begin{array}{l}\text { Toename in aangegeven voerkenmerk } \\
\text { voor het totale rantsoen }\end{array}$} & \multicolumn{2}{|c|}{$\begin{array}{c}\text { Verandering methaan ( } \mathbf{g} / \mathbf{k g} \text { ds graskuil) } \\
\text { aangegeven toename voerkenmerk }\end{array}$} \\
\hline & Totaal rantsoen (tabel 4.1 & Gecorrigeerd naar graskuil ds \\
\hline $100 \mathrm{~g} \mathrm{NDF} / \mathrm{kg}$ ds & 2.2 & 3.0 \\
\hline $100 \mathrm{~g}$ suiker $/ \mathrm{kg}$ ds & 1.4 & 1.9 \\
\hline $100 \mathrm{~g}$ ruw eiwit/ $\mathrm{kg}$ ds & -2.1 & -2.8 \\
\hline $100 \mathrm{~g}$ OEB $/ \mathrm{kg}$ ds & -2.5 & -3.4 \\
\hline $100 \mathrm{~g} \mathrm{DVE} / \mathrm{kg}$ ds & -7.9 & -10.7 \\
\hline $100 \mathrm{VEM} / \mathrm{kg}$ ds & -1.8 & -2.4 \\
\hline $10 \mathrm{~g}$ ruw vet $/ \mathrm{kg}$ ds & -1.8 & -2.4 \\
\hline $10 \% \operatorname{vcos}$ & -1.1 & -1.5 \\
\hline
\end{tabular}

Uit de meetgegevens in het project EmissieArm Veevoer blijkt dat de methaanemissie met $0,1 \mathrm{~g}$ methaan/kg ds graskuil toeneemt per extra dag hergroei, vanaf een basisniveau van 18,7 g methaan/kg ds graskuil voor het jongste groeistadium. Dit komt met een hergroeiperiode van 30 en 60 dagen dus neer op resp. 3 en $6 \mathrm{~g}$ extra methaan/ $\mathrm{kg}$ ds graskuil ten opzichte van het basisniveau ofwel resp. 21,7 en $24,7 \mathrm{~g}$ methaan/ $\mathrm{kg}$ ds graskuil. De range op basis van deze meetgegevens met een maximaal verschil van $6 \mathrm{~g}$ methaan/ $\mathrm{kg}$ ds graskuil is ruimer dan het maximale verschil van 4 g/aannames dat eerder werd aangehouden binnen het project FeedPrint. De gemeten range aan graskwaliteiten in het project EmissieArm Veevoer is naar verwachting echter extremer dan die in de reguliere melkveehouderij en om die reden lijken de aannames binnen FeedPrint nog steeds reëel voor de reguliere melkveehouderij. Er moet rekening worden gehouden met een grotere spreiding (zoals gemeten binnen EmissieArm Veevoer) als de groeiomstandigheden wisselend zijn en wanneer meer extensieve vormen van melkveehouderij doorgerekend worden (bijvoorbeeld bij gebruik van gras uit beheersgebieden, biologische landbouw, laat maaien in verband met broedseizoen, of abnormale weersomstandigheden die maken dat het maaimoment wordt uitgesteld). 
Een belangrijke kanttekening bij de huidige schattingen van methaan uit graskuil is dat de range op basis van de meetgegevens binnen EmissieArmVeevoer is afgeleid. Bij die afleiding is aangenomen dat de methaanemissie lineair verandert met het aantal dagen hergroei en dat de response op aantal dagen hergroei zoals onderzocht in het project EmissieArm Veevoer indicatief is.

\subsubsection{Ingekuilde snijmais}

Het effect van snijmaiskwaliteit werd experimenteel onderzocht in EmissieArm Veevoer waaruit bleek dat de methaanemissie daalt met toenemend ds gehalte van snijmais op het moment van oogsten. De reden hiervoor is het met het ds gehalte bij oogst gepaard gaande hogere aandeel zetmeel en de hogere bestendigheid van dat zetmeel tegen afbraak in de pens. Echter, een hoger zetmeelgehalte gaat gepaard met een lager NDF gehalte en dezelfde daling in methaanemissie kan ook worden uitgedrukt per eenheid verandering in NDF (spiegelen). De methaanemissie van snijmais daalde met $0,25 \mathrm{~g}$ methaan/10 g stijging van het zetmeelgehalte in de ds van snijmais. Wanneer gespiegeld wordt aan de verandering in het NDF gehalte (het complement van zetmeelstijging) dan is de daling $0,47 \mathrm{~g}$ methaan/10 $\mathrm{g}$ daling van het NDF gehalte in de ds van snijmais.

Een range van ds gehaltes van snijmais werd onderzocht tussen de $25 \%$ en $40 \% \mathrm{ds} / \mathrm{kg}$ gehele plant snijmais. Het laagste ds-gehalte van $25 \%$ is echter niet representatief voor de oogst in de praktijk die de snijmais juist bij hogere ds-gehaltes oogst. Bovendien gaf een kuil van een dergelijk jonge snijmais een a-typische uitkomsten wat betreft gemeten methaanemissie (Hatew et al, 2016). Wanneer alleen de ds-gehaltes van $28 \%, 32 \%$ en $40 \%$ in ogenschouw worden genomen, dan daalt de methaanemissie met $0,49 \mathrm{~g}$ methaan/10 $\mathrm{g}$ stijging in zetmeelgehalte (een daling van 0,83 $\mathrm{g}$ methaan/10 $\mathrm{g}$ daling in NDF gehalte). Het lijkt het meest realistisch om deze daling aan te houden voor het effect van oogstmoment van snijmais op methaanemissie in de KringLoopWijzer.

Deze uitkomsten werden verkregen voor een in 2014 veel gebruikte variant snijmais in Nederland. Voor andere varianten of rassen met een andere fysiologische ontwikkeling van de plant gedurende het groeiseizoen, of met gebruik van andere maisproducten (als MKS of CCM), kunnen andere relaties gelden voor de invloed van het van ds-gehalte bij oogst op de methaanemissie per kg ds. Het ligt echter wel in de verwachting dat dezelfde principes zoals waargenomen voor snijmais, ook geldig zijn voor die andere maisproducten (invloed zetmeelgehalte en - bestendigheid).

\subsubsection{Overige ruwvoeders}

Voor enkele producten is geen EF-waarde bekend hoewel die met regelmaat worden toegepast in melkveerantsoenen (bv. tarwestro, gerstestro, graszaadstro en koolzaadstro). Op basis van de lage verteerbaarheid van deze producten en het hoge NDF-gehalte lijkt een EF-waarde van $17 \mathrm{~g}$ methaan/kg ds reëel. Ook luzerne als ruwvoeder is niet apart doorgerekend echter hiervoor kunnen de gegevens voor luzernemeel gehanteerd worden. Ter vergelijking, grasmeel heeft vergelijkbare EFwaarden als gras als ruwvoeder.

\subsection{Conclusies}

De methaanemissie van graskuil neemt toe met zwaarte van de snede en het aantal dagen hergroei . Vooralsnog wordt volstaan met de aannames zoals opgenomen in Feedprint voor een hoge en lage opbrengst van vers gras, en voor de drie verschillende opbrengsten voor graskuil, met in beide gevallen een maximaal verschil in methaanemissie van $4 \mathrm{~g}$ methaan/kg gras(kuil) ds, en waardes voor vers gras die $1 \mathrm{~g}$ methaan/kg ds hoger zijn dan voor graskuil. Deze verschillen zijn niet toepasbaar voor extreme groeiomstandigheden en minder reguliere vormen van bedrijfsvoering en graslandmanagement.

De methaanemissie van een gemiddelde maiskuil daalt met $0.5 \mathrm{~g}$ methaan $/ \mathrm{kg}$ snijmais ds per $10 \mathrm{~g}$ stijging van het zetmeelgehalte, ofwel met $0.8 \mathrm{~g}$ methaan $/ \mathrm{kg}$ snijmais ds per $10 \mathrm{~g}$ daling in NDF gehalte. 


\section{$5 \quad$ Methaanemissie en mengvoedersamenstelling}

\subsection{Algemeen}

Het beschikbaar hebben van methaanemissiefactoren ( $\mathrm{EF}$, in $\mathrm{g}_{\mathrm{CH}}$ per $\mathrm{kg}$ ds) per voedermiddel maakt het mogelijk om bij de optimalisatie van de grondstoffensamenstelling (receptuur) van mengvoeders eisen te stellen aan de methaanemissie per kg mengvoer. De relevantie van deze reductieoptie hangt af van het handelingsperspectief; hoeveel reductie kan worden bereikt en tegen welke kosten?

Uit de vorige hoofdstukken is gebleken dat de EF van een voedermiddel kan verschillen in afhankelijkheid van het gevoerde rantsoen c.q. de wijze waarop de pens functioneert. Er zijn dan ook voor verschillende rantsoenen lijsten met EF voor grondstoffen gemaakt. Het is de vraag of het zinvol is om met verschillende EF lijsten te werken bij het optimaliseren van de receptuur van mengvoeders.

\subsection{Materiaal en methoden}

\subsubsection{Aanpak}

Het doel is inzicht krijgen in de impact van de grondstoffensamenstelling (receptuur) op de methaanemissie ( $\mathrm{g} / \mathrm{kg}$ droge stof) voor de in Nederland gebruikelijke range van mengvoeders. Het begeleidingsteam heeft gediscussieerd over de onderzoekaanpak, het aantal te optimaliseren mengvoeders en de nutritionele eisen (VEM, DVE, OEB, ruw eiwit en zetmeel) voor die mengvoeders. $\mathrm{Er}$ is ingeschat dat met 3 te optimaliseren mengvoeders het onderzoekdoel bereikt kan worden. Het gaat om een productiebrok, een eiwitrijke brok en een zetmeelrijke brok. De nutritionele eisen voor deze 3 mengvoeders (randvoorwaarden bij de optimalisatie) zijn door het begeleidingsteam gedefinieerd (Tabel 5.1).

Tabel 5.1 Nutritionele eisen (in $\mathrm{g} / \mathrm{kg}$ vers product) voor de drie onderzochte mengvoeders

\begin{tabular}{lccc} 
& Productiebrok & Eiwitbrok & \\
\hline VEM & 940 & 940 & 980 \\
\hline DVE & 105 & 180 & 100 \\
\hline OEB & 10 & 90 & -10 \\
\hline RE & 165 & 325 & 145 \\
\hline ZET & 100 & 60 & 220 \\
\hline
\end{tabular}

De impact van de grondstoffensamenstelling op de methaanemissie van de 3 mengvoeders in tabel 5.1 is onderzocht met de twee meest verschillende EF lijsten uit hoofdstuk 2. Dat zijn de EF lijsten $\mathrm{EF}_{0 \% \text { snijmais }}$ en $\mathrm{EF}_{80 \% \text { snijmais }}$ (Bijlage 1 ). Met die twee $\mathrm{EF}$ lijsten is onderzocht of het mogelijk is de methaanemissie te reduceren en welk effect dat heeft op de kostprijs van het mengvoer. Daarbij zijn aan de sturing op receptuur de randvoorwaarden 'geen eis aan de methaanemissie' (basisoptimalisatie), '5\% methaanreductie' en '10\% methaanreductie' meegegeven. De methaanreductie is uitgedrukt ten opzichte van de methaanemissie van het mengvoeder uit de basisoptimalisatie. Bijvoorbeeld, als de basisoptimalisatie een mengvoeder oplevert met $20 \mathrm{~g} \mathrm{CH}_{4}$ per $\mathrm{kg}$ ds, dan is de eis voor methaanemissie bij de optimalisaties $5 \%$ en $10 \%$ minder methaan respectievelijk 19 en $18 \mathrm{~g} \mathrm{CH}_{4}$ per $\mathrm{kg}$ ds. Tabel 5.2 geeft het schema met uitgevoerde optimalisaties weer. 
Tabel 5.2 Schema voor de uit te voeren receptuur optimalisaties

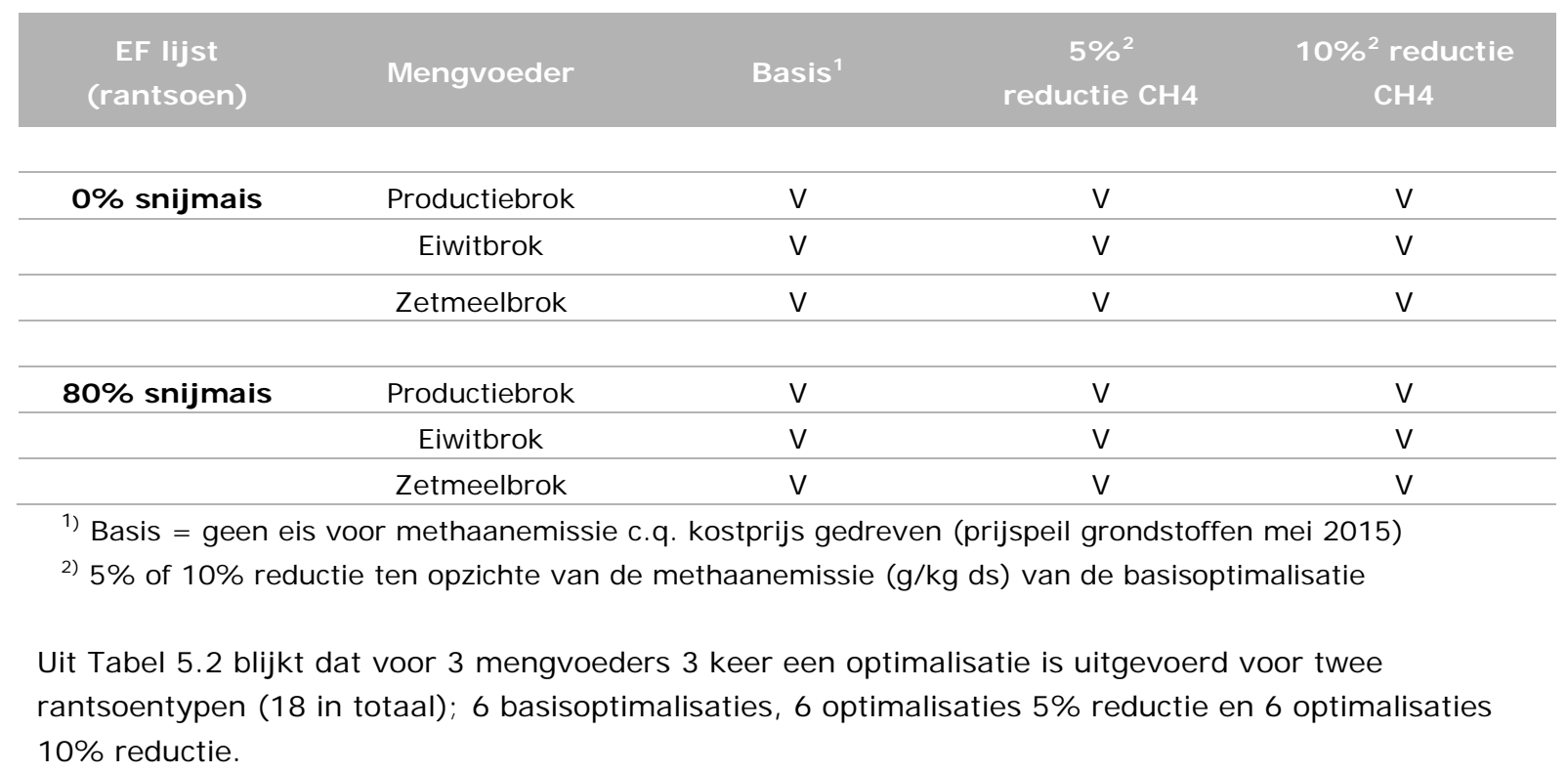

Voor de verschillende recepten is ook de kostprijs berekend. Uit het verschil in kostprijs tussen de basisoptimalisatie en de beide methaanreductie-optimalisaties ( $5 \%$ en $10 \%$ ) is de kosteneffectiviteit van dit handelingsperspectief berekend.

\subsubsection{Rekenmethodiek}

De optimalisatie van de receptuur voor mengvoeders is uitgevoerd met BESTMIX, een programma voor lineaire optimalisering. Het programma is gevoed met de actuele grondstoffensamenstelling en grondstoffenprijs zoals verzameld door WUR Livestock Research (betreft informatie van mei 2015) op basis van gegevens van NEVEDI. Voor alle in de lijst voorkomende grondstoffen is met behulp van de het model van Bannink et al, 2011 een EF afgeleid (zie hoofdstuk 2) voor verschillende typen rantsoenen. Deze grondstoffenlijst met bijbehorende EF is gelijk aan de in hoofdstuk 2 benoemde EF lijsten.

\subsection{Resultaten}

\subsubsection{Algemeen}

De basisoptimalisaties zijn conform praktijkoptimalisaties uitgevoerd op basis van eisen voor de minimale gehalten voor de verschillende nutriënten in combinatie met de laagste kostprijs. Daarbij zijn voor de methaanemissie geen eisen gesteld. De resultaten voor de productiebrok, eiwitbrok en zetmeelbrok zijn weergegeven in respectievelijk Bijlage $2 \mathrm{a}$, b en c. Daarin zijn de procentuele grondstoffensamenstelling (\%), de nutriëntensamenstelling (g/ kg product) en de prijs (€/100 kg product) opgenomen. De grondstoffensamenstelling van de 3 krachtvoeders is gegeven in bijlage 3 a, b en c. Daarmee zijn de 3 basismengvoeders gedefinieerd. In de basisoptimalisaties is ook de methaanemissie ( $\mathrm{g} / \mathrm{kg}$ product) opgenomen. Daarvoor zijn 2 getallen opgenomen die corresponderen met de EF lijsten '0\% snijmais' en ' $80 \%$ snijmais'.

Vervolgens zijn de 3 basismengvoeders opnieuw geoptimaliseerd met exact dezelfde optimalisatievoorwaarden, maar nu aangevuld met een eis voor methaanemissie. Die eis is of $5 \%$ of $10 \%$ lager dan de methaanemissie volgens de basisoptimalisatie. In Tabel 5.3 is het effect van deze extra eis op de nutriëntengehalten (VEM, DVE, OEB, ruw eiwit en zetmeel), de gerealiseerde methaanemissie en de kostprijs weergegeven. Het effect op de grondstoffensamenstelling en overige nutriënten is niet weergegeven. 
Tabel 5.3 Uitgangspunten en resultaten optimalisaties voor drie mengvoeders met EF lijsten $0 \%$ en $80 \%$ snijmais en $5 \%$ of $10 \%$ CH $\mathrm{H}_{4}$ reductie (in $\mathrm{g} / \mathrm{kg}_{\mathrm{b}} \mathrm{brok}$ )

\begin{tabular}{|c|c|c|c|c|c|c|c|c|c|}
\hline & VEM & $\begin{array}{l}\text { DVE } \\
\mathrm{g} / \mathrm{kg}\end{array}$ & $\begin{array}{l}\text { OEB } \\
\mathrm{g} / \mathrm{kg}\end{array}$ & $\begin{array}{l}\text { RE } \\
\text { g/ kg }\end{array}$ & $\begin{array}{l}\text { ZET } \\
\mathrm{g} / \mathrm{kg}\end{array}$ & $\begin{array}{c}\mathrm{EF} 0 \% \text { mais } \\
\mathrm{CH}_{4} \mathrm{~g} / \mathrm{kg}\end{array}$ & $\begin{array}{c}\text { EF } 80 \% \text { mais } \\
\mathrm{CH}_{4} \mathrm{~g} / \mathrm{kg}\end{array}$ & $\begin{array}{l}\text { Prijs } \\
€ / 100 \mathrm{~kg}\end{array}$ & $\begin{array}{c}\text { Extra kosten } \\
€ / 100 \mathrm{~kg}\end{array}$ \\
\hline \multicolumn{10}{|c|}{ Uitgangspunten (minimaal) } \\
\hline Productiebrok & 940 & 105 & 10 & 165 & 100 & -- & -- & & \\
\hline Eiwitbrok & 940 & 180 & 90 & 325 & 60 & -- & -- & & \\
\hline Zetmeelbrok & 980 & 100 & -10 & 145 & 220 & -- & -- & & \\
\hline
\end{tabular}

\section{Resultaten Productiebrok}

Basisoptimalisatie

$5 \%{ }^{1}$ reductie $0 \%$ snijmaïs

$10 \%{ }^{1}$ reductie $0 \%$ snijmaïs

$5 \%^{2}$ reductie $80 \%$ snijmaïs

$\begin{array}{llll}940 & 105 & 10 & 166 \\ 940 & 105 & 10 & 166\end{array}$

171

$10 \%{ }^{2}$ reductie $80 \%$ snijmaïs

$\begin{array}{llll}940 & 105 & 12 & 165 \\ 940 & 105 & 10 & 166\end{array}$

$201 \quad 16$

\section{Resultaten Eiwitbrok}

\section{Basisoptimalisatie}

$5 \%{ }^{1}$ reductie $0 \%$ snijmaïs

$10 \%{ }^{1}$ reductie $0 \%$ snijmaïs

$5 \%^{2}$ reductie $80 \%$ snijmaïs

$10 \%{ }^{2}$ reductie $80 \%$ snijmaïs

\begin{tabular}{lllll} 
& 940 & 180 & 98 & 325 \\
\hline aïs & 940 & 180 & 97 & 325 \\
maïs & 940 & 180 & 95 & 325 \\
maïs & 940 & 191 & 91 & 325 \\
\hline
\end{tabular}

60
60
60

60

\begin{tabular}{cccc}
\hline 8,82 & 19,00 & 17,05 & -- \\
\hline 7,88 & -- & 17,11 & 0,06 \\
\hline 6,94 & -- & 17,77 & 0,72 \\
-- & 18,05 & 17,07 & 0,02 \\
-- & 17,10 & 17,28 & 0,23
\end{tabular}

\section{Resultaten Zetmeelbrok}

\section{Basisoptimalisatie}

$5 \%{ }^{1}$ reductie $0 \%$ snijmaïs

$10 \%{ }^{1}$ reductie $0 \%$ snijmaïs

980

$5 \%{ }^{2}$ reductie $80 \%$ snijmaïs

100

$-2 \quad 145$

$\begin{array}{ll}145 & 22 \\ 145 & 242 \\ 175 & 26 \\ 145 & 281 \\ 145 & 32\end{array}$

$\begin{array}{ll}223 & 17 \\ 242 & 17 \\ 261 & 16,19 \\ 281 & \\ 322 & -1\end{array}$

$\begin{array}{cc}17,99 & 17,27 \\ 17,09 & -- \\ 16,19 & -- \\ -- & 16,41 \\ -- & 15,54\end{array}$

\begin{tabular}{ll}
16,97 & -- \\
17,65 & 0,68 \\
\hline 21,50 & 4,53 \\
17,58 & 0,61 \\
19,63 & 2,66
\end{tabular}

1) $5 \%$ en $10 \%$ reductie t.o.v. methaanemissie van het mengvoer uit de basisoptimalisatie EF $0 \%$ mais

2) $5 \%$ en $10 \%$ reductie t.o.v. methaanemissie van het mengvoer uit de basisoptimalisatie EF $80 \%$ mais 


\subsubsection{Methaanemissie en theoretische kosteneffectiviteit}

Het is mogelijk om de methaanemissie van reguliere standaard brok, eiwitrijke brok en zetmeelrijke brok met $5 \%$ en $10 \%$ te verminderen ten opzichte van een basisoptimalisatie zonder eis aan de methaanemissie. Ook als de randvoorwaarden van die mengvoeders strikt worden aangehouden. De handelingswijze 'strikt aanhouden' is hier de theoretische optimalisatie genoemd en resulteert in een theoretische kosteneffectief. Deze aanpassingen van de reguliere brok gaan gepaard met een toenemende kostprijs (zie Tabel 5.4).

Tabel 5.4 Verandering van de kosten van het grondstoffenpakket bij aanpassing van de receptuur om de methaanemissie ( $\mathrm{g} / \mathrm{kg}$ droge stof) te verminderen.

\begin{tabular}{lccccc}
$\begin{array}{l}\text { Prijsconsequentie } \\
\text { emissiereductie }(\Theta / 100 \mathrm{~kg})\end{array}$ & EF $0 \%$ snijmais & \multicolumn{3}{l}{ EF $80 \%$ snijmais } \\
& Reductie & $\mathbf{5 \%}$ & $\mathbf{1 0 \%}$ & $\mathbf{5 \%}$ & $\mathbf{1 0 \%}$ \\
\hline Productiebrok & & $+0,06$ & $+0,72$ & $+0,02$ & $+0,23$ \\
\hline Eiwitbrok & $+1,09$ & $+3,30$ & $+0,77$ & $+2,92$ \\
\hline Zetmeelbrok & $+0,68$ & $+4,53$ & $+0,61$ & $+2,66$ \\
\hline
\end{tabular}

Uit Tabel 5.4 blijkt dat er hoge kosten gepaard kunnen gaan met $\mathrm{CH}_{4}$ reductie via aanpassing van de receptuur van mengvoeders. Een stijging van meer dan $€ 1$,- per $100 \mathrm{~kg}$ mengvoer werd door het begeleidingsteam voorlopig als grenswaarde voor de kosteneffectiviteit aangemerkt, waarmee wordt aangegeven dat daarboven waarschijnlijk geen ruimte is voor praktische toepassing. Voor de productiebrok is een stijging van meer dan $€ 1$,- per $100 \mathrm{~kg}$ mengvoer niet waargenomen. Voor de zetmeelbrok is een stijging van meer dan $€ 1$,- per $100 \mathrm{~kg}$ mengvoer waargenomen voor de optimalisaties op 10\% methaanreductie en voor de eiwitbrok werd dat waargenomen voor 3 van de 4 optimalisatie. Voor de eiwitbrok bleef alleen EF80\% snijmais bij een reductie van $5 \%$ onder de $€ 1$,per $100 \mathrm{~kg}$ mengvoer.

\subsection{Praktische kosteneffectiviteit}

\subsubsection{Algemeen}

In tegenstelling tot de theoretische kosteneffectiviteit hanteert de praktische kosteneffectiviteit de randvoorwaarden 'naar de geest' en niet 'naar de letter'. Dat betekent bijvoorbeeld dat eisen aan minimale of maximale hoeveelheden per grondstof enigszins kunnen worden opgerekt in afhankelijkheid van de actuele kostprijs. Een eis van bijvoorbeeld maximaal $10 \%$ sojahullen kan in de praktijk ook op $11 \%$ of $12 \%$ worden gezet. Dat kan resulteren in een andere kosteneffectiviteit dan in het WUR onderzoek (paragraaf 5.3). Om daarin inzicht te krijgen heeft de Heus, onder leiding van productmanager J. Goelema, een praktijktest 'Optimaliseren mengvoeders naar methaanemissie' uitgevoerd. De praktijktest is tevens een goede gelegenheid om de toepasbaarheid en het gebruikersgemak te onderzoeken bij de praktische implementatie van de voorgestelde rekenregels.

\subsubsection{Praktijktest 'Optimaliseren mengvoeders naar methaanemissie'}

De praktijktest is in het derde kwartaal van 2015 uitgevoerd. In de test is de praktische kosteneffectiviteit in principe dezelfde werkwijze gevolgd als voor de theoretische kosteneffectiviteit (zie paragraaf 5.2). Het verschil is dat in de praktijktest de eisen niet absoluut zijn genomen en dat is gerekend met verwachtte termijnprijzen van 4 kwartalen (het laatste kwartaal van 2015 en de eerste 3 kwartalen van 2016). Ook zijn voor de nutritionele eisen van de te onderzoeken mengvoeders ( productiebrok, eiwitbrok en zetmeelbrok) de standaarden van De Heus aangehouden (tabel 5.5). 
Tabel 5.5 Nutritionele eisen De Heus (in $\mathrm{g} / \mathrm{kg}$ vers product) voor de drie onderzochte mengvoeders

\begin{tabular}{lcccc} 
& Productiebrok & Eiwitbrok & Zetmeelbrok & \\
VEM & 940 & 940 & 980 & 85 \\
\hline g DVE & 110 & 180 & -20 \\
\hline g OEB & 15 & 105 & 100 \\
\hline g Ruw eiwit & 165 & 330 & 300 \\
\hline g Zetmeel & 200 & 50 & 300 \\
\hline
\end{tabular}

\subsubsection{Basisoptimalisatie}

Voor de drie mengvoeders uit tabel 5.5. is een normale praktijkgrondstoffenoptimalisatie uitgevoerd (= basisoptimalisatie, zonder eis voor methaanemissie). De basisoptimalisatie is per mengvoer 4 keer uitgevoerd $\mathrm{nl}$. op basis van de verwachtte grondstoffenprijzen voor de komende 4 kwartalen. Voor iedere basisoptimalisatie is de methaanemissie per $\mathrm{kg}$ droge stof uitgerekend op basis van de EF lijsten $0 \%$ en $80 \%$ snijmais in het ruwvoerdeel van het rantsoen (tabel 5.6).

Tabel 5.6 Resultaten ( $\mathrm{g} \mathrm{CH}_{4} / \mathrm{kg}$ brok) basisoptimalisaties bij de verwachtte grondstoffenprijzen van de komende 4 kwartalen; voor drie mengvoeders en de twee EF lijsten $0 \%$ en $80 \%$ snijmais, zonder eis voor de methaanemissie.

\begin{tabular}{|c|c|c|c|}
\hline Type mengvoer & Kwartaal & EF $0 \%$ snijmais & EF $80 \%$ snijmais \\
\hline \multirow[t]{4}{*}{ Productiebrok } & 1 & 18,18 & 18,77 \\
\hline & 2 & 18,03 & 17,99 \\
\hline & 3 & 18,21 & 18,15 \\
\hline & 4 & 17,13 & 17,46 \\
\hline \multirow[t]{4}{*}{ Eiwitbrok } & 1 & 17,21 & 18,45 \\
\hline & 2 & 17,21 & 18,45 \\
\hline & 3 & 17,21 & 18,45 \\
\hline & 4 & 17,22 & 18,42 \\
\hline \multirow[t]{4}{*}{ Zetmeelbrok } & 1 & 18,53 & 18,16 \\
\hline & 2 & 18,24 & 17,86 \\
\hline & 3 & 18,24 & 17,86 \\
\hline & 4 & 18,35 & 17,96 \\
\hline
\end{tabular}

Uit tabel 5.6 blijkt dat de eiwitbrok en zetmeelbrok op basis van kosteneffectiviteit weinig variatie vertonen in methaanemissie per $\mathrm{kg}$ product. De methaanemissie ( $\mathrm{g} / \mathrm{kg}$ product) is voor deze typen mengvoer vrij constant en dat geldt voor beide EF lijsten. De productiebrok blijkt op basis van kosteneffectiviteit wel variatie in de methaanemissie te vertonen en die variatie is van vergelijkbare grootte als de variatie tussen de onderzochte typen mengvoer.

Het verschil in methaanemissie tussen EF0\% en EF80\% snijmais in het ruwvoerdeel van het rantsoen (EF0 minus EF80) is gemiddeld over de kwartalen voor de productiebrok $+1,2 \%$, voor de eiwitbrok $+7,1 \%$ en voor de zetmeelbrok $-2,1 \%$. Daarmee zijn voor de productie- en zetmeelbrok de verschillen tussen EF lijsten vergelijkbaar met de verschillen tussen de onderzochte typen mengvoer. Voor de eiwitbrok is het verschil tussen EF varianten duidelijk groter dan tussen de onderzochte typen mengvoer.

Voor EFO\% is de methaanemissie van de zetmeelbrok het hoogst en voor de eiwitbrok het laagst. Voor de EF80\% is dat juist andersom, de methaanemissie van de eiwitbrok is het hoogst en voor de zetmeelbrok het laagst.

\subsubsection{Optimaliseren met een eis voor methaanemissie}

$\mathrm{Na}$ de basisoptimalisatie is met dezelfde nutritionele eisen opnieuw een productie-, eiwit- en zetmeelbrok geoptimaliseerd maar nu met eisen aan de methaanemissie per kg product. Er is geoptimaliseerd met voor methaanemissie de eisen $5 \%$ en $10 \%$ lager dan de methaanemissie in de basisoptimalisatie. Vervolgens is vergeleken wat het effect van die eisen was op de kostprijs van het mengvoer (tabel 5.7). 
Tabel 5.7 Prijsconsequenties van de optimalisaties door De Heus voor drie mengvoeders met EF lijsten $0 \%$ en $80 \%$ snijmais en $5 \%$ en $10 \% \mathrm{CH}_{4}$ reductie (in $\mathrm{g} / \mathrm{kg}$ brok). Weergegeven zijn de minimale en maximale prijsverschillen op basis van de grondstoffenprijzen van 4 kwartalen (alle zijn prijsstijgingen).

\begin{tabular}{lllll} 
Prijsconsequentie emissiereductie & EF $0 \%$ snijmais & EF $80 \%$ snijmais \\
$\begin{array}{llll}\text { De Heus }(€ / 100 \mathrm{~kg}) \\
\text { Reductie }\end{array}$ & $\mathbf{5 \%}$ & $\mathbf{1 0}$ & $\mathbf{5 \%}$ & $\mathbf{1 0 \%}$ \\
\hline Productiebrok & $0,19-0,27$ & $0,55-0,64$ & $0,09-0,30$ & $0,41-0,73$ \\
\hline Eiwitbrok & $0,18-0,32$ & $0,45-0,68$ & $0,18-0,34$ & $0,53-0,75$ \\
\hline Zetmeelbrok & $0,48-0,73$ & $1,81-2,83$ & $0,42-0,67$ & $1,52-2,10$ \\
\hline
\end{tabular}

Uit tabel 5.7 blijkt enerzijds dat eisen met betrekking tot de methaanemissie per kg mengvoer kostprijsverhogend werken en anderzijds dat emissiereducties van $5 \%$ en $10 \%$ mogelijk zijn. De kostprijsstijging in deze praktijktest is vergelijkbaar met die van de P-reductie in rundveevoeders. Naast prijsconsequenties heeft de optimalisatie op methaanemissie ook effect op het grondstoffenpatroon van het mengvoer. Daar zitten mogelijk risico's aan, omdat daarmee het karakter van de brok verandert en er ongewenste neveneffecten kunnen optreden. De hier uitgevoerde praktijktest is niet geschikt om de relevantie van mogelijke neveneffecten te duiden, waardoor de praktijkimpact van de 'methaanoptimalisatie' voor dat deel onduidelijk blijft.

Uit vergelijking met de theoretische kosteneffectiviteit (tabel 5.4) blijkt dat de prijsconsequenties in de praktijk inderdaad geringer zijn. Daarmee wordt de conclusie dat de kosteneffectiviteit van de methaanreductie via de grondstoffensamenstelling van mengvoer in bijna de helft van de optimalisaties onvoldoende is genuanceerd. In de praktijktest werd de in paragraaf 5.3.2 genoemde grens van $€ 1$,- per $100 \mathrm{~kg}$ mengvoer alleen overschreden bij de optimalisaties EF0\% en EF80\% voor zetmeelbrok bij een reductie van $10 \%$. De extra speelruimte bij de praktijkoptimalisatie van de grondstoffensamenstelling van mengvoeders biedt mogelijkheden om de kosteneffectiviteit te beheersen. Door de te realiseren methaanreductie in $\mathrm{g} \mathrm{CH}_{4}$ per $\mathrm{kg}$ mengvoer ( $10 \%$ dan wel $5 \%$, of anders) af te stemmen op basis van kosteneffectiviteit kan een werkbaar concept gevonden worden. Echter, praktijkimplementatie zal afhangen van de vraag of sturen op de grondstoffensamenstelling van mengvoeders nog voldoende toegevoegde waarde heeft, wanneer eerst andere reductiemogelijkheden zijn toegepast (o.a. voerefficiëntie, ruwvoermanagement, dier- en mestmanagement).

\subsubsection{Implementeren nieuwe rekenregels}

Tijdens de praktijktest 'optimaliseren mengvoeders naar methaanemissie' bij De Heus zijn de in deze rapportage voorgestelde nieuwe rekenregels geïmplementeerd in de LP programmatuur. Hierbij zijn geen noemenswaardige problemen ondervonden. Ook bleek het werken met een extra nutritionele eis (grenzen aan de methaanemissie per kg product) goed mogelijk.

\subsection{Conclusies}

De nieuwe rekenregels in combinatie met EF lijsten is makkelijk implementeerbaar in de LP programmatuur van de diervoederindustrie

De kosteneffectiviteit zoals bepaald in de praktijktest en in een theoretisch benadering blijkt flink te kunnen verschillen. Het eisenpakket en de striktheid waarmee de eisen worden opgevolgd is sterk bepalend voor de te realiseren kosteneffectiviteit. Dat betekent dat er in de praktijk werkbare toepassingen mogelijk zijn. Het betekent ook dat zich in de praktijk situaties zullen voordoen waarbij de kosteneffectiviteit zwaarder weegt dan een voorgenomen emissiereductie per kg mengvoer.

De meerwaarde van krachtvoeroptimalisatie op methaanemissie om de methaanemissie op het melkveebedrijf te verminderen lijkt gering wanneer tevens andere reductiemaatregelen worden genomen. 


\section{Methaanemissie en mest-handling}

\subsection{Algemeen}

\subsubsection{Achtergrond}

Methaan $\left(\mathrm{CH}_{4}\right)$, met een Global Warming Potential (GWP) van $28 \mathrm{CO}_{2}$-equivalenten (Myhre et al, 2013), is na koolstofdioxide $\left(\mathrm{CO}_{2}\right.$, met een GWP van $1 \mathrm{CO}_{2}$-equivalent) kwantitatief gezien het belangrijkste broeikasgas (BKG). Volgens Coenen et al (2013) is $\mathrm{CH}_{4}$ verantwoordelijk voor $8 \%$ van de totale BKG-emissies in Nederland $\left(\mathrm{CO}_{2}: 86 \%\right.$; lachgas $\left.\left(\mathrm{N}_{2} \mathrm{O}\right): 5 \%\right)$. De landbouw is de belangrijkste bron van $\mathrm{CH}_{4}$ in Nederland: $60 \%$ van de totale $\mathrm{CH}_{4}$-emissie in Nederland is afkomstig van landbouwbronnen; $\mathrm{CH}_{4}$ is verantwoordelijk voor $57 \%$ van de totale BKG-emissies uit de landbouw in Nederland (en $\mathrm{N}_{2} \mathrm{O}$ voor de andere $43 \%$ ).

Figuur 6.1 is gebaseerd op data van 2011 en geeft een overzicht van de belangrijkste bronnen van $\mathrm{CH}_{4}$ in de Nederlandse landbouw. Er zijn 2 bronnen:

- De methaanemissie uit het maagdarmkanaal (enterisch). Dit is de grootste bron en goed voor $71 \%$ van de Nederlandse methaanemissie uit de landbouw en in Figuur 6.1 weergegeven als het donkere deel.

- De methaanemissie uit de opgeslagen mest. Deze bron is goed voor $29 \%$ van de Nederlandse methaanemissie uit de landbouw en is in Figuur 6.1 weergegeven als het lichtere deel.

De methaan uit het dier komt van endogene productie door pens- en darmfermentatie (enterische methaan). De methaan uit de opgeslagen mest komt van afbraak van organische stof onder anaerobe omstandigheden. Uit Figuur 6.1 blijkt dat rundvee de belangrijkste $\mathrm{CH}_{4}$-bron in de Nederlandse landbouw zijn. Van de totale $\mathrm{CH}_{4}$-emissies uit de landbouw is $83 \%$ rundvee gerelateerd, waarvan het overgrote deel (76\%) enterisch methaan betreft. Voor éénmagige dieren (met name varkens) is het juist omgekeerd en is mest de belangrijkste $\mathrm{CH}_{4}$-bron; ongeveer $33 \%$ betreft enterisch methaan.

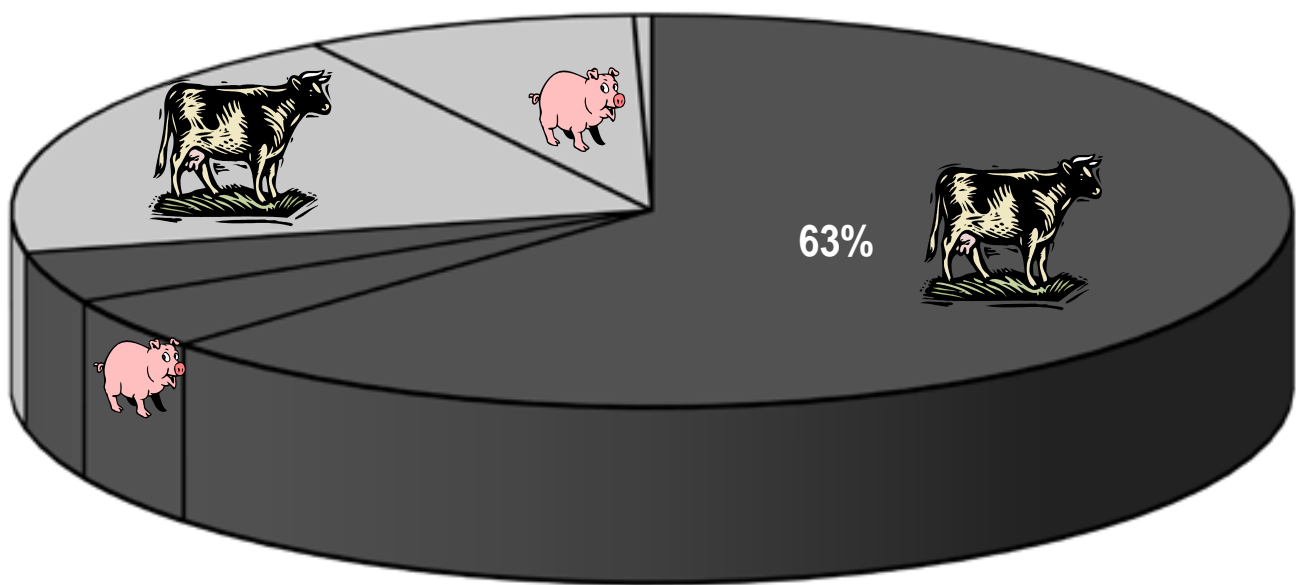

Figuur 6.1. Bronnen van methaanemissie in de landbouw, verdeeld per diercategorieën rundvee (afbeelding koe), varkens (afbeelding varken) een overige diersoorten (zonder afbeelding). Er is tevens onderscheid gemaakt tussen enterische methaan (donkere kleur) en methaan uit opgeslagen mest (lichte kleur).

Vermindering van de aan herkauwers gerelateerde methaanemissie is een belangrijk aandachtsgebied bij het verminderen van de methaanemissie uit de Nederlandse landbouw. Het gaat daar bij vooral om de melkveehouderij. Daarbinnen zijn 2 aandachtsgebieden te onderscheiden, enterische 
methaanemissie en methaanemissie uit de opgeslagen mest (Figuur 6.1). De reductieopties voor de enterische methaanemissie zijn beschreven door Šebek et al (2014). In dit hoofdstuk worden voor de Nederlandse melkveehouderij de reductieopties voor de methaanemissie uit de mestopslag beschreven.

De belangrijkste factoren die de productie van $\mathrm{CH}_{4}$ uit mest bepalen zijn dierfactoren en mesteigenschappen, die de activiteit van de methanogene bacteriën kunnen beïnvloeden (Tabel 6.1) .

Tabel 6.1 Bepalende factoren voor de emissie van $\mathrm{CH}_{4}$ uit mest (uit Groenestein et al, 2010).

\begin{tabular}{|c|c|}
\hline & $\mathrm{CH}_{4}$ \\
\hline \multicolumn{2}{|l|}{ Dierfactoren } \\
\hline \multicolumn{2}{|l|}{ Leeftijd dieren } \\
\hline Hoeveelheid en samenstelling voer & + \\
\hline \multirow{4}{*}{\multicolumn{2}{|c|}{ 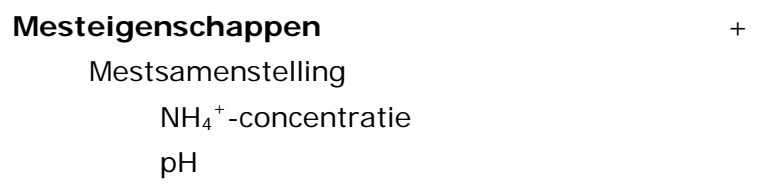 }} \\
\hline & \\
\hline & \\
\hline & \\
\hline Organische stof concentratie & - \\
\hline Droge stofgehalte & $7^{*}$ \\
\hline $\mathrm{C} / \mathrm{N}$-ratio & + \\
\hline $\mathrm{O}_{2}$-concentratie & - \\
\hline Mestoppervlakte & + \\
\hline Leeftijd mest / Opslagtijd & - \\
\hline \multirow[t]{3}{*}{ Mesttemperatuur } & 0 \\
\hline & + \\
\hline & + \\
\hline
\end{tabular}

\subsubsection{Dierfactoren}

De mestproductie van een melkveestapel is afhankelijk van het aantal dieren, de voeropname, de vertering van het voer, en het productieniveau en de efficiëntie waarmee het verteerde voer wordt omgezet in melk en vlees. Naarmate de mestproductie toeneemt zal ook de absolute hoeveelheid substraat voor de aanwezige $\mathrm{CH}_{4}$ - producerende bacteriën toenemen, waardoor een hogere $\mathrm{CH}_{4}$ emissie uit de stal (mestkelder) en/of buitenopslag van mest te verwachten is. Een mogelijke maatregel om de $\mathrm{CH}_{4}$-emissie in de mestopslag te reduceren is om mestopslag te voorkomen en minder mest in de stal te produceren. Dit kan door minder dieren in de stal te houden of door de hoeveelheid voer en de voersamenstelling te veranderen om een hogere omzetting van voer naar dierlijk product te realiseren. Sturen met de voersamenstelling om de enterische emissie te verminderen is in de vorige hoofdstukken uitgebreid aan de orde geweest. Echter, voermaatregelen hebben niet alleen effect op de enterische emissies, maar via de mestsamenstelling ook op de methaanemissie uit de mestopslag (Hindrichsen et al, 2005). Dit tweeledige effect van voermaatregelen en de mogelijke afwentelingen tussen beide methaanbronnen maakt het reduceren van de methaanemissie uit de mestopslag via beter verteerbaar voer ingewikkeld. In principe geeft beter verteerbaar voer enerzijds meer $\mathrm{CH}_{4}$ omdat het fermentatieproces in de pens wordt bevorderd en anderzijds minder $\mathrm{CH}_{4}$ omdat er minder verteerbare componenten in de mest komen. Maar hierop zijn veel uitzonderingen mogelijk (bijvoorbeeld als de verandering in het voer vooral tot extra vertering in de dunne darm leidt in plaats van extra fermentatie in de pens of wanneer het profiel van vluchtige vetzuurvorming in de pens verschuift of wanneer de organische stof in de mest sneller en/of beter afbreekbaar wordt tijdens mestopslag). De balans of optelsom van al deze factoren bepaalt of 'beter verteerbaar voer' leidt tot $\mathrm{CH}_{4}$ reductie. Voor toepassing in de praktijk is in hoge mate vakmanschap nodig. 


\subsubsection{Mesteigenschappen}

\section{Mestsamenstelling}

De activiteit van de $\mathrm{CH}_{4}$ vormende microbiële populatie in de mest is mede afhankelijk van de mestsamenstelling. Bepalende factoren zijn de concentratie aan minerale stikstof, organische stof, de $\mathrm{pH}$ en de beschikbaarheid van zuurstof in de mest (J un et al, 1999; Groenestein, 2006):

- De $\mathrm{CH}_{4}$-productie wordt geremd door de aanwezigheid van ammonia $\left(\mathrm{NH}_{3}\right)$ (Chen et al, 2008), waardoor meer ammonium $\left(\mathrm{NH}_{4}{ }^{+}\right)$in de mest zal leiden tot lagere $\mathrm{CH}_{4}$-emissies bij opslag van mest. Dit kan door de ammoniakemissie te beperken via korstvorming in de mest (Ambus en Petersen, 2005; Petersen et al, 2005; Hansen et al, 2009).

- $\quad$ De optimale $\mathrm{pH}$ voor $\mathrm{CH}_{4}$-productie in mest ligt tussen 7-8.

- De concentratie aan organische stof in de mest is van invloed op de $\mathrm{CH}_{4}$-emissie omdat het (direct en indirect) dient als voedingsbron voor de aanwezige bacteriën.

- Het zuurstofgehalte beïnvloedt de $\mathrm{CH}_{4}$ vorming in mest, omdat $\mathrm{CH}_{4}$ alleen onder anaerobe omstandigheden wordt gevormd. Hierdoor is de $\mathrm{CH}_{4}$-productie groter in drijfmest dan in vaste mest. Echter, indien er in vaste mest verdichting plaatsvindt (waardoor meer anaerobe omstandigheden optreden) kunnen ook daar hoge $\mathrm{CH}_{4}$-emissies optreden (Osada et al, 2000; Chadwick et al, 2011). Het is daarom belangrijk om anaerobe omstandigheden in de mest zo veel mogelijk te voorkomen, zodat methaan-oxiderende bacteriën de productie van $\mathrm{CH}_{4}$ kunnen remmen (Szanto et al, 2007). Dit kan door de drijfmest te beluchten, het mestmanagement te veranderen van drijfmest naar (niet verdichte) vaste mest of vaste mest aeroob op te slaan (compostering).

\section{Mestoppervlakte}

De mestoppervlakte heeft geen direct effect op de $\mathrm{CH}_{4}$-emissies bij drijfmest, aangezien $\mathrm{CH}_{4}$ niet oplosbaar is en chemische evenwichten tussen vloeistof- en gasfase voor $\mathrm{CH}_{4}$-vorming geen rol van betekenis hebben. Voor vaste mest betekent het vergroten van het mestoppervlak dat het contactoppervlak tussen lucht en mest wordt vergroot waardoor er meer aerobe omstandigheden worden gecreëerd. Daardoor zal de $\mathrm{CH}_{4}$-emissie uit de vaste mest beperkt worden.

Leeftijd of opslagtijd van mest

De opslagtijd van de mest heeft effect op de $\mathrm{CH}_{4}$-emissie, aangezien in oudere mest al langer microbiële activiteit is geweest, de mest meer afgebroken is en daardoor meer $\mathrm{CH}_{4}$-vorming heeft plaats gevonden. Een mogelijke maatregel om de $\mathrm{CH}_{4}$-emissies te reduceren is dan ook de mest zo kort mogelijk op te slaan. Daarnaast wordt in oudere mest de $\mathrm{CH}_{4}$ hoger door een lager ammoniumen ammoniakgehalte (als gevolg van vervluchtiging) dan in verse mest.

\section{Mesttemperatuur}

De omzettingen in de mest die leiden tot $\mathrm{CH}_{4}$-emissies zijn biologische processen die sneller verlopen bij een hogere (mest-)temperatuur. Het koelen van de mest is een goede mogelijkheid om $\mathrm{CH}_{4}$ emissies te reduceren. Dit kan in de stal gebeuren of door de combinatie van frequent uit de stal verwijderen met buitenopslag bij lagere temperaturen (Sommer et al, 2004, 2009; Umetsu et al, 2005).

\subsection{Mestopslag in de stal}

\subsubsection{Minder mest}

Zoals in 6.1.2 is aangegeven, heeft de hoeveelheid geproduceerde mest een directe relatie met de totale $\mathrm{CH}_{4}$-productie: hoe meer mest geproduceerd wordt, hoe hoger de totale (absolute) $\mathrm{CH}_{4}$-emissie uit de (binnen en/ of buiten) mestopslag. Door minder mest in de stal te produceren en op te slaan kan de $\mathrm{CH}_{4}$-productie uit mest daardoor verlaagd worden. Dit kan door bijvoorbeeld:

- Minder dieren in de stal te houden, bij voorkeur dieren die geen of weinig melk produceren, of door de melkproductie per dier te verhogen. Dit zal de relatieve $\mathrm{CH}_{4}$-emissie per $\mathrm{kg}$ geproduceerde melk omlaag brengen. 
- $\quad$ Minder mest per dier, door minder maar beter verteerbaar voer te gebruiken. Dit zal leiden tot een betere benutting van de energie in het voer door het dier, waardoor minder $\mathrm{CH}_{4}$ (endogeen) ontstaat. Daarnaast zal minder organische stof in de mest terecht komen, waardoor ook minder $\mathrm{CH}_{4}$ uit de mest zal worden geproduceerd.

\subsubsection{Vaste mest of drijfmest}

Over het algemeen produceren systemen met vaste mest meer broeikasgasemissie $\left(\mathrm{CH}_{4}+\mathrm{N}_{2} \mathrm{O}\right)$ dan drijfmestsystemen (Tabel 6.2). De reden daarvoor is de hogere $\mathrm{N}_{2} \mathrm{O}$ emissie. Dat neemt niet weg dat er ten opzichte van drijfmestsystemen een flinke reductie in $\mathrm{CH}_{4}$-emissies gehaald kan worden in systemen met vaste mest. Mits goed uitgevoerd (vaak en veel stro gebruiken) kan voor melkvee de reductie in $\mathrm{CH}_{4}$-emissie rond $65-70 \%$ bedragen (Husted, 1994; Kulling et al, 2001). Ook de methaanconversiefactoren (MCF) voor opgeslagen vaste mest van het IPCC (2006) zijn veel lager dan voor drijfmest (zonder korst) namelijk $2 \%$ t.o.v. $17 \%$ bij een buitentemperatuur van $10^{\circ} \mathrm{C}$. Echter, bij vaste mest kunnen anaerobe omstandigheden optreden als verdichting van het strobed (mengsel van stro en mest) plaatsvindt. Dit kan spelen bij looppaden van dieren, of door de aanwezigheid van natte dichte plekken en dan kunnen er alsnog hoge $\mathrm{CH}_{4}$-emissies ontstaan (Hassouna et al, 2010; Edouard et al, 2012; Mosquera et al, 2005).

Tabel 6.2 Broeikasgasemissies uit vaste mest ten opzichte drijfmest

\begin{tabular}{lcccc} 
Mestsoort/ diercategorie & $\mathbf{N}_{\mathbf{2}} \mathbf{O}$ & $\mathbf{C H}_{\mathbf{4}}$ & BKG & Referenties \\
\hline Melkvee & +85 & +33 & +48 & Edouard et al (2012) \\
\hline Melkvee & - & -66 & - & Husted (1994) \\
\hline Melkvee & +350 & -69 & +328 & Kulling et al (2001) \\
\hline
\end{tabular}

1) - $_{\text {. }}$ reductie en $+=$ toename van de emissie van het broeikasgas

\subsubsection{Mest kort opslaan}

Hoe langer de mest opgeslagen wordt, hoe meer tijd beschikbaar is om 1 ) de populatie van microben in de mest toe te laten nemen en 2) de productie van $\mathrm{CH}_{4}$ en $\mathrm{N}_{2} \mathrm{O}$ uit de mest te stimuleren. Als de mest in een externe opslag wordt gebracht neemt de verblijftijd in de mestput in de stal af. De omstandigheden zijn in een externe opslag over het algemeen minder gunstig voor emissies (lagere temperatuur; zie 6.2.4 mest koelen). Tevens is het door snellere verwijdering uit de stal mogelijk om de mest te behandelen (bijv. vergisting) om emissies verder te reduceren. Vaste mest kan mogelijk direct naar een afnemer worden afgezet.

Door de opslagtijd van mest te verkorten kunnen de $\mathrm{CH}_{4}$ - en $\mathrm{NH}_{3}$ - emissies worden gereduceerd (Hristov et al, 2012). Het effect is afhankelijk van de methode en frequentie van mestverwijdering uit de stal. Uitgaande van een verdeling van mest tussen vloer en mestkelder van 70:30, zou door de mest kort in de stal op te slaan een maximale $\mathrm{CH}_{4}$-emissiereductie van $30 \%$ in de stal haalbaar moeten zijn. Het frequent verwijderen van mest uit de stal vraagt niet alleen extra opslagcapaciteit buiten de stal, maar ook aanvullende maatregelen bij de buitenopslag van mest om de winst in de stal niet in de buitenopslag te verliezen. Door de mest frequent uit de stal te verwijderen kan die verder worden behandeld om de $\mathrm{CH}_{4}$-emissies verder te reduceren, of juist toe te laten nemen en te gebruiken als vervanging van fossiele brandstoffen (zie 6.4.2).

Echter, voor melkvee zijn geen meetgegevens beschikbaar om het effect van mestopslagduur op $\mathrm{CH}_{4-}$ vorming te kwantificeren. De beschikbare data voor varkens laten reducties in $\mathrm{CH}_{4}$-emissie zien die variëren tussen 40\% en 86\% (Tabel 6.3; Amon et al, 2007; Haeusserman et al, 2006; Groenestein et al, 2012). De MCF van IPCC (2006) laten zien dat methaanemissie uit kort opgeslagen mest (minder dan een maand) veel lager is dan de methaanemissie uit lang opgeslagen mest. De MCF voor kort en lang opgeslagen mest onder dezelfde omstandigheden bedragen respectievelijk $3 \%$ (voor zowel $10^{\circ} \mathrm{C}$ als $\left.23^{\circ} \mathrm{C}\right)$ en $17 \%\left(10^{\circ} \mathrm{C}\right)$ en $>60 \%\left(23^{\circ} \mathrm{C}\right)$ van de maximaal haalbare methaanproductie. Door de opslagtijd van mest te verkorten moet de mest vaker op het veld worden toegediend. Dit kan zowel positieve als negatieve effecten hebben, afhankelijk van het seizoen. 
Tabel 6.3 Broeikasgasemissies in de stal bij korte ten opzichte van lange mestopslag in de stal

\begin{tabular}{|c|c|c|c|c|c|}
\hline & & & Effect $^{1}$ op & & Referentie \\
\hline Beschrijving & $\begin{array}{l}\text { Mestsoort/ dierc } \\
\text { ategorie }\end{array}$ & $\mathrm{N}_{2} \mathrm{O}$ & $\mathrm{CH}_{4}$ & BKG & \\
\hline Verwijdering na elke ronde & Varkens & $-39 \%$ & $-56 \%$ & $-51 \%$ & Amon et al (2007) \\
\hline $\begin{array}{l}\text { Verwijdering na elke ronde + } \\
\text { kelder schoonmaken }\end{array}$ & Varkens & - & $-40 \%$ & - & $\begin{array}{l}\text { Haeusserman et al } \\
\text { (2006) }\end{array}$ \\
\hline Frequent mest verwijderen & Biggen & $0 \%$ & $-50 \%$ & $-50 \%$ & $\begin{array}{l}\text { Groenestein et al } \\
(2012)\end{array}$ \\
\hline Frequent mest verwijderen & Vleesvarkens & $0 \%$ & $-86 \%$ & $-86 \%$ & $\begin{array}{l}\text { Groenestein et al } \\
\text { (2012) }\end{array}$ \\
\hline
\end{tabular}

1) ${ }_{-}=$reductie en $+=$toename van de emissie van het broeikasgas

\subsubsection{Mest koelen}

Door mest te koelen daalt de temperatuur van de mest, waardoor de microbiële activiteit wordt verminderd en daarmee de emissies. Bij temperaturen beneden $10^{\circ} \mathrm{C}$ is weinig tot geen $\mathrm{CH}_{4}$-productie te verwachten en daarboven hangt het reductie effect af van de gerealiseerde verlaging in temperatuur. Daarom is deze maatregel effectiever in de stal dan in de buitenopslag. In landen met een lage gemiddelde temperatuur is een vorm van mest koelen de combinatie van mest kort opslaan in de stal en dan buiten opslaan. Het effect van mest koelen in de stal is groter in landen met een relatief hoge gemiddelde buitentemperatuur (Sommer et al, 2009). Husted (1994) rapporteerde een reductie in $\mathrm{CH}_{4}$-emissie van 38\% door mestopslag in de warme zomermaanden te vermijden (mest toedienen vóór juni in plaats van in september). Groenestein et al (2012) gaan uit van een reductie in $\mathrm{CH}_{4}$ productie van $7 \%$ per ${ }^{\circ} \mathrm{C}$ en rapporteren voor varkens mogelijke reducties van $30-46 \%$ in $\mathrm{CH}_{4}$ emissies na het koelen van mest in de stal (mestkelder) tot een temperatuur van $10{ }^{\circ} \mathrm{C}$ (Tabel 6.4). Dezelfde aanname werd door Sommer et al (2004) gebruikt om de reductie in $\mathrm{CH}_{4}$ productie (31\% reductie) uit varkensmest opgeslagen in een buitenopslag (met een buitentemperatuur van $10{ }^{\circ} \mathrm{C}$ ) te bepalen. Voor melkvee ontbreken gegevens, maar het aanbrengen van een mestkoelingssysteem in melkveestallen is technisch mogelijk. Of daarmee dezelfde reductie percentages mogelijk zijn als bij varkens moet nader onderzocht worden, omdat bij rundveedrijfmest korstvorming makkelijker optreedt dan bij varkens. Korstvorming kan de ammoniakemissie beperken en via hogere ammonium gehaltes in de mest de methaan productie remmen.

Tabel 6.4 Methaanemissie in de stal bij gekoelde mest ten opzichte van ongekoelde mest

\begin{tabular}{|c|c|c|c|}
\hline Maatregel & Diercategorie & Effect ${ }^{1}$ op & Referentie \\
\hline \multicolumn{4}{|c|}{$\mathrm{CH}_{4}$} \\
\hline Mestkoeling & Varkens & $-31 \%$ & Sommer et al (2004) \\
\hline \multirow[t]{4}{*}{ tot $10^{\circ} \mathrm{C}$} & Vleesvarkens & $-43 \%$ & Groenestein et al (2012) \\
\hline & Kraamzeugen & $-46 \%$ & Groenestein et al (2012) \\
\hline & Dragende zeugen & $-33 \%$ & Groenestein et al (2012) \\
\hline & Biggen & $-30 \%$ & Groenestein et al (2012) \\
\hline
\end{tabular}

\subsubsection{Mestputten schoonmaken}

Bij het leeg maken van een mestput blijft onder in de mestput altijd een kleine hoeveelheid mest achter die niet kan worden opgezogen. In deze mest zitten bacteriën die actief blijven waardoor verse mest die in de mestput terecht komt wordt 'geënt' door de oude mest zodat de verse mest sneller methaan emitteert. In de melkveehouderij is het niet gebruikelijk om drijfmestputten schoon te maken, omdat het onpraktisch is (stallen zijn nooit leeg) en gevaarlijk. Vaste mest is eenvoudiger uit de stallen te verwijderen waarbij ook achterblijvende mestresten weg-geschept kunnen worden. 


\subsection{Mestopslag buiten de stal}

\subsubsection{Mest afdekken}

De methaanvorming vermindert niet door mest af te dekken of in een mestzak op te slaan. In principe wordt de methaanproductie zelfs gestimuleerd, omdat de uitwisseling van zuurstof tussen de mest en de omringende lucht vermindert en de anaerobe omstandigheden in de mest toenemen. Bij drijfmest zal dit niet zoveel uitmaken, omdat het al een anaeroob milieu is. Afdekken van vaste mest resulteert wel in een toename van anaerobe omstandigheden, maar of het ook leidt tot extra $\mathrm{CH}_{4}$-emissies wordt

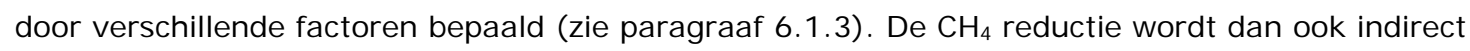
gerealiseerd door de (extra) geproduceerde methaan op te vangen of af te fakkelen (reductie in $\mathrm{CO}_{2^{-}}$ equivalenten). Voor het afdekken van vaste rundveemest met folie rapporteerde Chadwick (2005) zeer verschillende en niet consistente resultaten (Tabel 6.6) afhankelijk van de mate van verdichting van de afgedekte mest en het temperatuursverloop in de mesthoop.

Voor het afdekken van rundveedrijfmest geeft de literatuur aan dat door het toepassen van een semipermeabele afdekking lagere $\mathrm{CH}_{4}$ en $\mathrm{NH}_{3}$ emissies, maar hogere $\mathrm{N}_{2} \mathrm{O}$ emissies zullen optreden (Sommer et al, 2000; Guarino et al, 2006; Van der Zaag et al, 2008; Hansen et al, 2009; Nielsen et al, 2010). De $\mathrm{N}_{2} \mathrm{O}$ emissies zijn echter laag en het effect op de totale broeikasgasemissie is klein (Tabel 6.5). Van der Zaag et al (2009) vonden, na het afdekken van rundveedrijfmest met een dikke laag stro $(>15 \mathrm{~cm})$, een afname van de $\mathrm{CH}_{4}$ emissie en een toename van de $\mathrm{N}_{2} \mathrm{O}$ emissie, met als resultaat een reductie van 23-24\% in broeikasgasemissies (Tabel 6.5). Guarino et al (2006) rapporteerden een toename in $\mathrm{CH}_{4}$ emissies wanneer drijfmest wordt afgedekt met een dunne laag stro, maar afdekken met een dikkere laag stro had voor rundvee geen invloed op de emissies (ten opzichte van niet afgedekte drijfmest). Afdekken met een vast dek resulteerde voor rundveedrijfmest in reducties van $4-16 \%$ (Clemens et al, 2006).

Tabel 6.5 Broeikasgasemissies uit rundveedrijfmest, afgedekte ten opzichte van open opslag

\begin{tabular}{|c|c|c|c|c|c|}
\hline \multirow[t]{2}{*}{ Maatrege } & & \multicolumn{3}{|c|}{ Effect ${ }^{1}$ op } & \multirow[t]{2}{*}{ Referentie } \\
\hline & & $\mathrm{N}_{2} \mathrm{O}$ & $\mathrm{CH}_{4}$ & BKG & \\
\hline \multicolumn{6}{|l|}{ Strodek } \\
\hline \multirow[t]{4}{*}{ Rundvee } & $15 \mathrm{~cm}$ & $+57 \%$ & $-25 \%$ & $-23 \%$ & Van der Zaag et al (2009) \\
\hline & $30 \mathrm{~cm}$ & $+100 \%$ & $-27 \%$ & $-24 \%$ & Van der Zaag et al (2009) \\
\hline & $7 \mathrm{~cm}$ & - & $+37 \%$ & - & Guarino et al (2006) \\
\hline & $14 \mathrm{~cm}$ & - & $+3 \%$ & - & Guarino et al (2006) \\
\hline
\end{tabular}

\begin{tabular}{llllll} 
Vast dek & & & & & \\
\hline Rundvee & Winter & $-13 \%$ & $-14 \%$ & $-13 \%$ & Clemens et al (2006) \\
\hline Zomer & Winter & $+20 \%$ & $-16 \%$ & $-11 \%$ & Clemens et al (2006) \\
\hline Rundvee, & Zomer & $+2 \%$ & $-29 \%$ & $-4 \%$ & Clemens et al (2006) \\
\hline
\end{tabular}

1) $-=$ reductie en $+=$ toename van de emissie van het broeikasgas

Ook een natuurlijk korst op drijfmest (zoals vaak het geval bij rundvee) kan, door oxidatie van de geproduceerde $\mathrm{CH}_{4}$ in de diepere mestlagen, de emissies van $\mathrm{CH}_{4}$ reduceren. Het IPCC (2006) geeft een reductie van $40 \%$ aan op basis van expert judgement in combinatie met literatuurgegevens (Mangino et al 2001, Sommer et al 2000 en Husted, 1994). Door korstvorming wordt ook de $\mathrm{NH}_{3}$ emissie flink gereduceerd met 50\%-80\% (Misselbrook et al, 2005, Smith et al, 2007 en Sommer et al, 1993). Een negatief neveneffect is een mogelijke toename in $\mathrm{N}_{2} \mathrm{O}$ emissies (Gerber et al, 2013).

Het afdekken van mest met een laag stro kan wel tot minder methaanemissie leiden. Niet omdat er minder methaan wordt gevormd, maar omdat de gevormde methaan in de strolaag door methanotrophe/aerobe bacteriën wordt gebruikt als energiebron en zo wordt omgezet in CO2. Het effect is afhankelijk van de methode van afdekking en of het om vaste mest gaat (Tabel 6.6) of drijfmest (Tabel 6.6). Voor afdekken van vaste rundveemest met stro rapporteerde Yamulki (2006) 
een $\mathrm{CH}_{4}$-reductie van 45-50\%. De verwachting is dat afdekking de emissies van $\mathrm{NH}_{3}$ ook zullen verminderen (Chadwick, 2005; Webb et al, 2012; Clemens and Ahlgrimm, 2001).

Tabel 6.6 Broeikasgasemissie uit vaste rundveemest, afgedekte ten opzichte van open opslag

\begin{tabular}{|c|c|c|c|c|c|}
\hline \multirow[t]{2}{*}{ Afdekking } & & \multicolumn{3}{|c|}{ Effect ${ }^{1}$ op } & \multirow[t]{2}{*}{ Referentie } \\
\hline & & $\mathrm{N}_{2} \mathrm{O}$ & $\mathrm{CH}_{4}$ & BKG & \\
\hline \multicolumn{6}{|l|}{ Stro } \\
\hline Rundvee, reguliere bedrijven & & $-42 \%$ & $-45 \%$ & $-42 \%$ & Yamulki (2006) \\
\hline Rundvee, biologische bedrijven & & $-11 \%$ & $-50 \%$ & $-14 \%$ & Yamulki (2006) \\
\hline \multicolumn{6}{|l|}{ Plastic folie } \\
\hline \multirow[t]{3}{*}{ Melkvee, vaste mest } & Periode 1 & $-70 \%$ & $-6 \%$ & $-33 \%$ & Chadwick (2005) \\
\hline & Periode 2 & $+2000 \%$ & $-81 \%$ & $-19 \%$ & Chadwick (2005) \\
\hline & Periode 3 & $-54 \%$ & $+120 \%$ & $+111 \%$ & Chadwick (2005) \\
\hline
\end{tabular}

1) $-=$ reductie en $+=$ toename van de emissie van het broeikasgas

\subsubsection{Drijfmest beluchten}

Het beluchten van drijfmest (lucht door de mest blazen) wordt in Nederland vooralsnog voornamelijk gebruikt voor het verwerken van kalvergier in combinatie met opslag buiten de stal. Het gaat daarbij om het verwijderen van stikstof uit de mest via het stimuleren van de nitrificatie/denitrificatie processen, maar onder deze aërobe omstandigheden wordt ook de emissie van $\mathrm{CH}_{4}$ geremd.

Het verwijderen van stikstof uit drijfmest gebeurt in cycli van wel/niet beluchten. Tijdens het beluchten zorgen bepaalde micro-organismen voor de omzetting van ammonium naar nitraat/nitriet (nitrificatie), waarbij organische koolstofverbindingen worden omgezet naar $\mathrm{CO}_{2}$. Wanneer de mest niet meer belucht wordt zorgen andere micro-organismen onder anaërobe omstandigheden voor denitrificatie, de omzetting van nitraat en nitriet naar stikstofgas $\left(\mathrm{N}_{2}\right)$. Wanneer de nitrificatie en denitrificatie processen niet optimaal verlopen zal het ongewenste broeikasgas $\mathrm{N}_{2} \mathrm{O}$ worden geproduceerd. Na een aantal cycli nitrificatie/denitrificatie wordt de mest door bezinking in een dunne fractie (effluent, $75-80 \%$ van ingaand volume) en een dikke fractie (slib, $20-25 \%$ van ingaand volume) gescheiden. Het effluent bevat weinig stikstof en fosfaat en kan direct op het land worden uitgereden (afzet binnen de landbouw). De dikke fractie kan verder worden verwerkt en, mits gehygiëniseerd, buiten de landbouw worden afgezet.

Het verminderen van de methaanemissie door beluchten van drijfmest is effectief, maar voor rundveedrijfmest zijn weinig gegevens beschikbaar. Alleen Amon et al, 2006 hebben met rundveemest gewerkt en rapporteerden een reductie in $\mathrm{CH}_{4}$-emissie van $57 \%$. Na verrekening van een gelijktijdige toename in $\mathrm{NH}_{3}$ - en $\mathrm{N}_{2} \mathrm{O}$-emissies bleek de totale reductie in broeikasgasemissies $43 \%$ te bedragen (Tabel 6.7). Deze reductie wordt met gegevens van metingen aan varkensdrijfmest onderbouwd. Martinez et al (2003) rapporteren reducties in $\mathrm{CH}_{4}$-emissie van $70-99 \%$ na beluchten van varkens drijfmest. Loyon et al (2007) een reductie van $87 \%$, en Thompson et al (2004) een reductie van $47 \%$.

Tabel 6.7 Broeikasgasemissies uit de mestopslag bij beluchten ten opzichte van niet beluchten

\begin{tabular}{|c|c|c|c|c|c|}
\hline \multirow[t]{2}{*}{ Maatregel } & & \multicolumn{3}{|c|}{ Effect ${ }^{1}$ op } & \multirow[t]{2}{*}{ Referentie } \\
\hline & & $\mathrm{N}_{2} \mathrm{O}$ & $\mathrm{CH}_{4}$ & BKG & \\
\hline \multicolumn{6}{|l|}{ Beluchting } \\
\hline Melkvee & & $+144 \%$ & $-57 \%$ & $-43 \%$ & Amon et al (2006) \\
\hline \multirow[t]{2}{*}{ Varkens } & Periode 1 & - & $-99 \%$ & - & Martinez et al (2003) \\
\hline & Periode 2 & - & $-70 \%$ & - & Martinez et al (2003) \\
\hline Varkens & & - & $-87 \%$ & - & Loyon et al (2007) \\
\hline Varkens & & $-44 \%$ & $-47 \%$ & - & Thompson et al (2004) \\
\hline
\end{tabular}

1) $-=$ reductie en $+=$ toename van de emissie van het broeikasgas 
Het beluchten van mest in de stal is in principe ook mogelijk, maar praktisch gezien voor drijfmest moeilijk te realiseren. Voor vaste mest (bijvoorbeeld vrijloopstallen) ligt dat wel binnen de mogelijkheden, maar er is geen informatie beschikbaar over de te verwachten effecten.

Mogelijk negatieve neveneffecten van beluchting zijn hogere emissies van $\mathrm{N}_{2} \mathrm{O}$ en $\mathrm{NH}_{3}$ (Willers et al, 1996; Béline et al, 1999; Molodovskaya et al, 2008) en een toename van het gebruik van fossiele energie door toepassing van een beluchtingsinstallatie).

\subsubsection{Vaste mest composteren}

Het doel van compostering is een vermindering van de mestmassa en het mestvolume, waardoor het mestproduct (compost) gemakkelijker te transporteren is. Compostering is een biologisch proces waarbij bepaalde micro-organismen (in aanwezigheid van zuurstof) voor de omzetting van organische stof in stabiele verbindingen zorgen. Tijdens het composteringsproces wordt warmte geproduceerd, waardoor een deel van het water uit de mest verdampt (afname van de mestmassa en -volume) en ziektekiemen worden gedood. Compostering kan voor alle dikke mestfracties en droge mestsoorten worden toegepast. Compost van mest wordt zowel binnen de landbouw als buiten de landbouw afgezet. Om het eindproduct exportwaardig te maken moet tijdens het composteringsproces gedurende tenminste 60 minuten een temperatuur van $70^{\circ} \mathrm{C}$ optreden.

Composteren kan op verschillende manieren worden uitgevoerd:

- Intensieve versus extensieve compostering. Bij extensieve of passieve compostering wordt de mest op hopen gestort en één of meerdere keren omgezet. Dit vindt meestal in de open lucht plaats en kan enkele maanden duren voordat de compostering compleet is. Bij intensieve of actieve compostering wordt lucht door de mest geblazen en de mest continu omgezet. Dit zorgt voor een versnelling in het composteringsproces. Intensieve compostering vindt voornamelijk plaats in gesloten ruimtes.

- Aerobe versus anaerobe compostering. Compostering vindt plaats in de aanwezigheid van zuurstof (aerobe compostering) of onder zuurstofloze omstandigheden (anaerobe compostering). De aerobe omstandigheden zorgen voor lagere $\mathrm{CH}_{4}$ emissies.

De resultaten van aerobe compostering met betrekking tot $\mathrm{CH}_{4}$ emissie zijn wisselend. Amon et al (2001) rapporteerden voor de zomer een reductie van $90 \%$, maar voor de winter een toename van $32 \%$ in methaanemissie na actief composteren (beluchten en omzetten opgeslagen vaste mest) ten opzichte van passief (anaerobe) composteren. Ook de observaties van Pattey et al (2005), met een reductie van $81 \%$ en $\mathrm{Hao}$ et al (2001), met een toename van $29 \%$, zijn niet consistent. Lopez-Real en Baptista (1996) rapporteerden lagere $\mathrm{CH}_{4}$ emissies na actief composteren ten opzichte van passief composteren. Uit de beschikbare data (Tabel 6.8) kan niet geconcludeerd worden dat aerobe opslag van vaste mest (actief composteren) over het algemeen leidt tot lagere $\mathrm{CH}_{4}$-emissies.

Tabel 6.8 Broeikasgasemissies uit vaste mest bij aeroob ten opzichte van anaeroob composteren

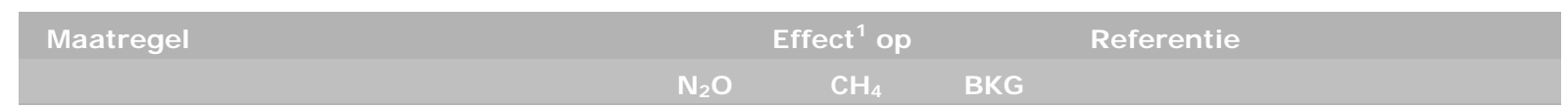

Aeroob vs. Anaeroob

Composteren

$\begin{array}{llllll}\text { Melkvee } & \text { Zomer } & -35 \% & -90 \% & -78 \% & \text { Amon et al (2001) } \\ \text { Melkvee } & \text { Winter } & -41 \% & +32 \% & -7 \% & \text { Amon et al (2001) } \\ \text { Melkvee } & & +44 \% & -81 \% & -34 \% & \text { Pattey et al (2005) } \\ \text { Melkvee } & & +73 \% & +29 \% & +36 \% & \text { Hao et al (2001) }\end{array}$

1) - = reductie en $+=$ toename van de emissie van het broeikasgas

Nadelen van intensief composteren is een mogelijke toename in energiegebruik, en de risico of hogere emissies van $\mathrm{NH}_{3}$ en $\mathrm{N}_{2} \mathrm{O}$ (Gerber et al, 2013; Pattey et al, 2005; Hao et al, 2001; Jiang et al, 2011; Tao et al, 2011; Webb et al, 2012). 


\subsubsection{Drijfmest verdunnen}

Het doel van mest verdunnen met water is om lagere gehalten in de mest te creëren en daardoor de $\mathrm{CH}_{4}$ emissies te verminderen. Martinez et al (2003) rapporteren voor rundveedrijfmest $57 \%$ reductie bij $67 \%$ verdunning en voor varkensmest $35 \%$ reductie bij 50\% verdunning (Tabel 6.9 ).

Tabel 6.9 In de literatuur gerapporteerde effecten van verdunning

\begin{tabular}{|c|c|c|c|}
\hline \multirow[t]{2}{*}{ Maatregel } & & Effect ${ }^{1}$ op & Referentie \\
\hline & \multicolumn{3}{|c|}{$\mathrm{CH}_{4}$} \\
\hline \multirow[t]{2}{*}{ Verdunning } & Varkens, drijfmest & $-35 \%$ & Martinez et al (2003) \\
\hline & Rundvee, drijfmest & $-57 \%$ & Martinez et al (2003) \\
\hline
\end{tabular}

\subsection{Mest bewerken/verwerken}

\subsubsection{Mest scheiden}

Het doel van mestscheiding is het verkrijgen van een dunne en een dikke mestfractie ten behoeve van verdere verwerking (bijvoorbeeld de dikke fractie composteren) en direct afzetten (bijvoorbeeld uitrijden van de dunne fractie op het land), of een combinatie van beide (bijvoorbeeld de export van mestkorrels na het drogen en pelleteren van de dikke fractie). Mestscheiding wordt voor zowel varkens- als voor rundveemest toegepast. De mestproducten (dunne en dikke fractie) worden voornamelijk binnen de landbouw afgezet.

Opslag van de dunne en dikke fracties na mestscheiding resulteert in lagere $\mathrm{CH}_{4}$ en hogere $\mathrm{N}_{2} \mathrm{O}$ emissies ten opzichte van opslag van ruwe drijfmest (Tabel 6.10). Hierdoor kan het effect op de totale broeikasgasemissie wisselend zijn. Zo rapporteren Martinez et al (2003), Mosquera et al (2011) en Dinuccio et al (2008) voor varkens drijfmest een totale reductie in broeikasgasemissie van $9-40 \%$, terwijl Dinuccio et al (2008) een toename in broeikasgasemissie van $41 \%$ rapporteren. Ook voor drijfmest van rundvee verschillen de effecten op de totale broeikasgasemissie. Fangueiro et al (2008a), Dinuccio et al (2008) en Amon et al (2006) rapporteren een afname in broeikasgasemissie van 9-39\%, maar Dinuccio et al (2008) en Mosquera et al (2011) rapporteren een toename in broeikasgasemissie van $4-25 \%$.

Tabel 6.10 Broeikasgasemissies uit opslag van gescheiden mest ten opzichte van ruwe drijfmest

\begin{tabular}{|c|c|c|c|c|c|}
\hline \multirow[t]{2}{*}{ Maatregel } & \multirow[t]{2}{*}{ Diersoort } & \multicolumn{3}{|c|}{ Effect ${ }^{1}$ op } & \multirow[t]{2}{*}{ Referentie } \\
\hline & & $\mathrm{N}_{2} \mathrm{O}$ & $\mathrm{CH}_{4}$ & BKG & \\
\hline \multirow[t]{10}{*}{ Scheiding } & Varkens, $5{ }^{\circ} \mathrm{C}$ & - & $-8 \%$ & $-8 \%$ & Dinuccio et al (2008) \\
\hline & Varkens, $25^{\circ} \mathrm{C}$ & Toename & $+3 \%$ & $+41 \%$ & Dinuccio et al (2008) \\
\hline & Varkens & Toename & $-93 \%$ & $-29 \%$ & Mosquera et al (2011) \\
\hline & Varkens & - & $-18 \%$ & & Martinez et al (2003) \\
\hline & Varkens & - & $-40 \%$ & & Martinez et al (2003) \\
\hline & Rundvee, $5{ }^{\circ} \mathrm{C}$ & - & $+4 \%$ & $+4 \%$ & Dinuccio et al (2008) \\
\hline & Rundvee, $25^{\circ} \mathrm{C}$ & - & $-9 \%$ & $-9 \%$ & Dinuccio et al (2008) \\
\hline & Rundvee & $+1133 \%$ & $-34 \%$ & $-23 \%$ & Fangueiro et al (2008a) \\
\hline & Rundvee + houten dek & $+10 \%$ & $-42 \%$ & $-39 \%$ & Amon et al (2006) \\
\hline & Rundvee & Toename & $-42 \%$ & $+25 \%$ & Mosquera et al (2011) \\
\hline
\end{tabular}

1) ${ }_{-}=$reductie en $+=$toename van de emissie van het broeikasgas

\subsubsection{Mest vergisten}

Het doel van mest vergisten is het omzetten van organische stof in biogas (grotendeels $\mathrm{CH}_{4}$ en $\mathrm{CO}_{2}$ ). Dit gebeurt onder zuurstofloze (anaerobe) omstandigheden met behulp van bepaalde microorganismen. Daarnaast zorgt vergisten voor de afbraak van vluchtige organische verbindingen (inclusief bepaalde geurstoffen), de omzetting van organische stikstof in ammonium, en het doden 
van ziektekiemen en onkruidzaden. Een belangrijk kenmerk van dit proces is dat alleen gemakkelijk afbreekbare organische stoffen worden afgebroken. Om een beter rendement te krijgen kunnen andere producten toegevoegd worden aan de mest en mee vergisten (dit wordt co-vergisting genoemd). Vergisting wordt voor varkens- en rundveemest toegepast. Het mesteindproduct (digestaat) kan uitgereden worden op het land (afzet binnen de landbouw), maar ook verder in een dunne en een dikke fractie worden gescheiden. De dikke fractie kan daarna door drogen, pelleteren en hygiëniseren worden verwerkt tot exportwaardige mestkorrels (met relatief hoge gehaltes aan N, P en K) voor afzet buiten de landbouw. De dunne fractie kan op het land uitgereden worden, maar ook verder verwerkt worden.

Clemens et al (2006) rapporteren reducties van 14-48\% en Amon et al (2006) van 59\% in broeikasgasemissie (hoge reductie in $\mathrm{CH}_{4}$ emissie, maar toename in $\mathrm{N}_{2} \mathrm{O}$ emissie) tijdens de opslag van vergiste rundvee drijfmest ten opzichte van opslag van ruwe mest (Tabel 6.11). Sommer et al (2000) vonden ook hogere $\mathrm{N}_{2} \mathrm{O}$ emissies ( $26 \%$ hogere emissies) tijdens opslag van vergiste mest ten opzichte van onvergiste rundveedrijfmest.

Tabel 6.11 Broeikasgasemissies van opgeslagen vergiste mest ten opzichte van niet-vergiste mest

\begin{tabular}{|c|c|c|c|c|c|}
\hline \multirow[t]{2}{*}{ Maatregel } & & \multicolumn{3}{|c|}{ Effect ${ }^{1}$ op } & \multirow[t]{2}{*}{ Referentie } \\
\hline & & $\mathrm{N}_{2} \mathrm{O}$ & $\mathrm{CH}_{4}$ & BKG & \\
\hline \multirow[t]{3}{*}{ Vergisting } & Rundvee, korst, winter & $-9 \%$ & $-32 \%$ & $-14 \%$ & Clemens et al (2006) \\
\hline & Rundvee, korst, zomer & $+49 \%$ & $-68 \%$ & $-48 \%$ & Clemens et al (2006) \\
\hline & Rundvee, houten dek & $+41 \%$ & $-67 \%$ & $-59 \%$ & Amon et al (2006) \\
\hline
\end{tabular}

1) ${ }_{-}=$reductie en $+=$toename van de emissie van het broeikasgas

Vergisting kan ook de emissies van broeikasgassen bij het uitrijden van mest op het land beïnvloeden, maar de effecten zijn niet consistent. Dat blijkt uit de (beperkt) beschikbare literatuur.

Voor methaan vonden Wulf et al (2002), zowel op grasland als op bouwland, een lagere emissie bij uitrijden (met een sleepslangenmachine) van vergiste t.o.v. onvergiste rundveemest. Amon et al (2006) rapporteerden hogere $\mathrm{CH}_{4}$ emissies bij uitrijden van vergiste t.o.v. onvergiste rundveemest op grasland. Clemens et al (2006) vonden geen significant verschil in $\mathrm{CH}_{4}$ emissie tussen vergiste en onvergiste rundveemest bij uitrijden (met een sleepvoetenmachine) op grasland.

Voor lachgas vonden Clemens en Huschka (2001) en Amon et al (2006) een lagere emissie bij toediening van vergiste mest t.o.v. onvergiste rundveemest. Wulf et al (2002) vonden op grasland een hogere $\mathrm{N}_{2} \mathrm{O}$ emissies bij toediening van vergiste t.o.v. onvergiste mest op grasland, maar de verschillen waren niet significant. Clemens et al (2006) vonden ook geen significant verschil in $\mathrm{N}_{2} \mathrm{O}$ emissie tussen vergiste en onvergiste mest bij uitrijden (met een sleepvoetenmachine) op grasland. Op bouwland werd geen significant verschil gevonden tussen beide mestsoorten.

Wanneer het biogas wordt opgevangen en gebruikt, kan dit het energieverbruik omlaag brengen. Aandachtspunt is het zo min mogelijk laten ontsnappen van biogas (met hoge concentraties $\mathrm{CH}_{4}$ ) uit de opslag. In de literatuur worden $\mathrm{CH}_{4}$-verliezen uit de opslag van het biogas van 5-20\% gerapporteerd (Bjurling en Svärd, 1998; Sommer et al, 2001).

\subsection{Overig}

\subsubsection{Toevoegmiddelen}

Het doel van toevoegmiddelen is het stoppen of vertragen van het proces waarbij $\mathrm{CH}_{4}$ wordt gevormd (methanogenese). De toe te voegen producten zijn zuren en antibacteriële middelen. Het reducerend effect kan variëren tussen $47 \%$ en $99 \%$ (Tabel 6.12), maar voor melkvee zijn weinig gegevens beschikbaar. Petersen et al (2012) voegden zwavelzuur toe aan melkveedrijfmest en vonden een reductie in $\mathrm{CH}_{4}$-emissie van $67-87 \%$ (en bijna $100 \%$ reductie in $\mathrm{NH}_{3}$-emissies). Hetzelfde toevoegmiddel gaf voor varkensdrijfmest een reductie tussen 94 en 99\% (Petersen et al, 2014). Het remmen van de methanogenese kan worden verklaard door de aanwezigheid van zwavel in de mest ( Lin et al, 2001; Hao et al, 2005). Martinez et al (2003) vonden een reductie van tussen $47 \%$ en $64 \%$ in $\mathrm{CH}_{4}$-emissies na toevoeging van verschillende middelen aan varkensdrijfmest. 
Tabel 6.12 Effect van toevoegmiddelen op de methaanemissie uit opgeslagen drijfmest

\begin{tabular}{|c|c|c|c|}
\hline \multirow[t]{2}{*}{ Maatregel } & & Effect ${ }^{1}$ op & Referentie \\
\hline & \multicolumn{3}{|c|}{$\mathrm{CH}_{4}$} \\
\hline \multicolumn{4}{|c|}{ 1. Toevoegmiddel } \\
\hline $\mathrm{NX}_{23}$ & Varkens, drijfmest & $-47 \%$ & Martinez et al (2003) \\
\hline Stalosan & Varkens, drijfmest & $-54 \%$ & Martinez et al (2003) \\
\hline Biosuper & Varkens, drijfmest & $-64 \%$ & Martinez et al (2003) \\
\hline \multirow[t]{4}{*}{ Zwavelzuur } & Melkvee, drijfmest ( $\mathrm{pH} 5.5$ ) & $-67 /-87 \%$ & Petersen et al (2012) \\
\hline & Varkens, drijfmest, stalopslag (pH 5.6) & $-99 \%$ & Petersen et al (2014) \\
\hline & Varkens, drijfmest, buitenopslag ( pH & $-94 \%$ & Petersen et al (2014) \\
\hline & $6.6)$ & & \\
\hline
\end{tabular}

1) $-=$ reductie en $+=$ toename van de emissie van methaan

Mogelijke negatieve neveneffecten zijn een verhoging van de $\mathrm{N}_{2} \mathrm{O}$-emissies na toediening van een zuur en de hoge kosten voor de installatie en het zuur zelf. Verder kan toediening van aangezuurde mest leiden tot een $\mathrm{pH}$-daling van de bodem.

\subsubsection{Affakkelen}

Een goede reductieoptie voor methaanemissie uit de mestopslag in de stal is de geproduceerde mest zo snel mogelijk in een gesloten opslag brengen. Hierdoor komt de $\mathrm{CH}_{4}$-productie pas goed op gang wanneer de mest zich al in de gesloten opslag bevindt. Die mestopslag moet gasdicht worden gemaakt, zodat het geëmitteerde $\mathrm{CH}_{4}$ (en andere gassen) naar een fakkelinstallatie kunnen worden geleid. Mogelijk dat bij putafzuiging ook een groot deel van de methaanemissie kan worden afgevangen. Bij de verbranding wordt $\mathrm{CH}_{4}$ omgezet in verbrandingsenergie, koolstofdioxide en water. Koolstofdioxide is een minder schadelijk broeikasgas dan methaan waardoor de totale emissie van broeikasgassen afneemt.

\subsubsection{Beweiden}

Door de koeien langer te laten beweiden, wordt meer mest buiten de stal onder aerobe omstandigheden geproduceerd, waardoor de $\mathrm{CH}_{4}$-productie uit mest wordt verlaagd. Een negatief neveneffect kan een hogere $\mathrm{N}_{2} \mathrm{O}$ emissies en/of nitraatuitspoeling zijn. Daarnaast kan de enterische $\mathrm{CH}_{4}$-emissie toenemen door een minder efficiënte voerbenutting tijdens beweiding.

\subsection{Methaanemissie bij mest aanwenden}

De meeste modellen die bedrijfsemissies voor methaan berekenen zetten de methaanemissie bij het aanwenden van mest op nul. De reden is dat deze bron van methaan zo klein is ten opzichte van de andere methaanbronnen dat de bijdrage wegvalt in de ruis/onzekerheid van die grotere emissiebronnen. De methaanemissie bij mest aanwenden kan wel beïnvloed worden, maar voor het verminderen van de totale methaanemissie blijft het niet relevant.

Met gescheiden mest zijn studies gedaan naar de methaanemissie bij mesttoediening. De resultaten waren wisselend voor wat betreft de emissies van $\mathrm{CH}_{4}$ en $\mathrm{N}_{2} \mathrm{O}$. Amon et al (2006) vonden bijvoorbeeld hogere $\mathrm{CH}_{4}$ en $\mathrm{N}_{2} \mathrm{O}$ emissies na uitrijden van de dunne fractie van rundveemest t.o.v. de onbehandelde mest. Ook Fangueiro et al (2008b) rapporteerden hogere $\mathrm{N}_{2} \mathrm{O}$ emissies na het (bovengronds) uitrijden van de dunne fractie van rundveemest t.o.v. onbehandelde mest, maar Bertora et al (2008) vonden lagere $\mathrm{N}_{2} \mathrm{O}$ emissies na uitrijden van de dunne fractie van varkensmest t.o.v. onbehandelde mest. 


\subsection{Conclusies}

Het gemiddelde Nederlandse melkveebedrijf heeft een ligboxenstal waarin de mest als drijfmest wordt opgeslagen. Op zo'n bedrijf is ongeveer $20 \%$ van de methaanemissie afkomstig uit mest. Deze bron van methaan kan flink gereduceerd worden (30\%-90\%), waarmee de totale methaanemissie op het gemiddelde Nederlandse melkveebedrijf 6\%-18\% kan worden verminderd. Daarmee wordt de totale broeikasgasemissie van het melkveebedrijf met $3 \%-9 \%$ verminderd.

Vermindering van de methaanemissie uit mest kan gepaard gaan met een toename van de lachgasemissie uit mest. Hierdoor wordt het effect van reductie van de methaanemissie op de totale broeikasgasemissie van het melkveebedrijf gedrukt. Dit effect is echter klein, omdat van de $\mathrm{CO}_{2}$ equivalenten uit mest slechts ongeveer $4 \%$ van de lachgasemissie komt.

De kwantitatieve methaanemissie uit mest $\left(\mathrm{CO}_{2}\right.$ equivalenten per jaar in $\left.\mathrm{kg}\right)$ op het melkveebedrijf wordt bepaald door de hoeveelheid geproduceerde mest, de mestsamenstelling, de mestopslag en het bewerken van de mest. De methaanemissie bij aanwenden is verwaarloosbaar klein.

Opties voor verminderen methaanemissie uit drijfmest, inclusief reductiepotentieel (in \% van de oorspronkelijke methaanemissie uit mest):

- De hoeveelheid geproduceerde mest. Sturen via dieraantallen en via het voerspoor. Er zijn voor de reductiepotentie geen onderzoeksgegevens beschikbaar.

- De mestsamenstelling. Belangrijke factoren zijn $\mathrm{pH}$, zuurstofgehalte en ammoniumgehalte.

o Verlagen van de $\mathrm{pH}$ door toevoegen van zuren en antibacteriële middelen. Reductiepotentie afhankelijk van toevoegmiddel, $65 \%-85 \%$.

o Verhogen van het zuurstofgehalte door beluchten. Reductiepotentie $50 \%-60 \%$.

o Verhogen ammoniumgehalte (tegengaan ammoniakemissie). Reductiepotentieel niet bekend.

- De mestopslag. Belangrijke factoren zijn de duur van mestopslag, de temperatuur in de mestopslag en het afdekken van de mest.

o Opslagduur in de stal verkorten (mest naar opslag buiten de stal). Reductiepotentieel afhankelijk van frequentie van mest verwijderen, $50 \%-85 \%$.

o Temperatuur verlagen door koelen mest in de stal (of in buitenopslag). Reductiepotentieel $30 \%-45 \%$.

- Mest afdekken met strolaag. Reductiepotentieel afhankelijk van dikte strolaag en buitentemperatuur, $5 \%-25 \%$

- Mestbewerking. Belangrijke mogelijkheden zijn mest vergisten, mest scheiden en mest verdunnen.

o Mest vergisten (combinatie met opslagduur in de stal verkorten). Reductiepotentieel $30 \%$ $70 \%$.

o Mest scheiden en de dunne en dikke fractie apart opslaan. Reductiepotentieel $10 \%-40 \%$

o Mest verdunnen door toevoegen van water. Reductiepotentieel $50 \%-60 \%$.

De kwantitatieve methaanemissie uit mest $\left(\mathrm{CO}_{2}\right.$ equivalenten per jaar in $\left.\mathrm{kg}\right)$ op het melkveebedrijf verminderen door over te stappen van een drijfmestsysteem naar een systeem met vaste mest. Mits het vaste mest systeem goed wordt gemanaged is het reductiepotentieel (in \% van de oorspronkelijke methaanemissie uit drijfmest) $60 \%-70 \%$.

Opties voor verminderen methaanemissie uit vaste mest, inclusief reductiepotentieel (in \% van de oorspronkelijke methaanemissie uit drijfmest):

- Afdekken met stro. Reductiepotentieel afhankelijk van dikte strolaag en buitentemperatuur, $40 \%-80 \%$.

- Composteren van de mest. Het reductiepotentieel is laag met zeer wisselende resultaten waarbij de methaanemissie ook kan toenemen.

Overige opties om de methaanemissie uit mest te verminderen 
- Affakkelen geproduceerde methaan. In combinatie met Mestopslag buiten de stal in afgesloten ruimte en verkorten verblijfduur mest in de stal. Reductiepotentieel niet bekend maar lijkt zeer groot (indien werkbaar).

\subsection{Conclusies}

\subsection{Rekenregels}

De enterische methaanemissie van melkvee kan goed en nauwkeurig geschat worden met een praktisch toepasbare variant van de 'state of the art' Nederlandse IPCC Tier 3 benadering voor de berekening van de methaanemissie uit het maagdarmkanaal van melkvee.

Voor een goede schatting van de enterische methaanemissie is het nodig om rekening te houden met 3 factoren: Rantsoensamenstelling, voeropnameniveau en ruwvoerkwaliteit.

- De factor 'rantsoensamenstelling' kan geïmplementeerd worden op basis van rantsoendifferentiatie naar het aandeel snijmaissilage in het ruwvoerdeel van het rantsoen.

- De factor 'voeropnameniveau' kan geïmplementeerd worden via correctie van de berekende methaanemissie per $\mathrm{kg}$ droge stof met $0,21 \mathrm{~g}$ per $\mathrm{kg}$ voeropnameverschil ten opzichte van een opname van $18,5 \mathrm{~kg}$ droge stof per dier per dag.

- De factor 'ruwvoerkwaliteit' kan geïmplementeerd worden, maar het is nog niet duidelijk hoe. De reden hiervoor is dat de correctiemogelijkheden invoer vragen die nu nog niet in de kringloopwijzer beschikbaar zijn. In een vervolgproject wordt hier verder aandacht aan besteed.

Voorlopig lijkt implementatie mogelijk door voor vers gras, graskuil en snijmaissilage op basis van kwaliteitskenmerken correcties door te voeren ten opzichte van de gemiddelde methaanemissie ( $\mathrm{g} / \mathrm{kg} \mathrm{ds}$ ) voor die ruwvoeders:

o Voor vers gras en graskuil wordt op basis van snedezwaarte (licht en zwaar) de methaanemissie ( $\mathrm{g} / \mathrm{kg}$ ds) met respectievelijk -2 en $+2 \mathrm{~g} / \mathrm{kg}$ ds gecorrigeerd voor een lichte en zware snede.

o Voor snijmaissilage wordt gecorrigeerd voor òf zetmeel gehalte òf NDF gehalte. De methaanemissie daalt met $0,5 \mathrm{~g}$ methaan/ $\mathrm{kg}$ droge stof per $10 \mathrm{~g}$ stijging van het zetmeelgehalte cq. daalt met $0,8 \mathrm{~g}$ methaan $/ \mathrm{kg}$ droge stof per $10 \mathrm{~g}$ daling in NDF gehalte.

De methaanemissie van een melkveerantsoen $(\mathrm{g} / \mathrm{kg} \mathrm{ds})$ kan berekend worden als het gewogen gemiddelde van de methaanemissie van alle rantsoencomponenten. Daartoe is met de Nederlandse IPCC Tier 3 benadering voor alle bekende voedermiddelen de methaanemissie of emissiefactor (EF) bepaald en in een lijst weergegeven (EF-lijst). Om de factor 'rantsoensamenstelling' mee te wegen zijn voor verschillende rantsoenen EF lijsten gemaakt.

Voor een juiste berekening van de methaanemissie van rantsoenen met een verschillende samenstelling (= percentage snijmaissilage in het ruwvoerdeel) zijn drie EF lijsten nodig; voor rantsoenen met $0 \%, 40 \%$ en $80 \%$ snijmais in het ruwvoer. Met deze drie EF-lijsten kan op basis van interpolatie voor ieder tussenliggend percentage snijmaissilage in het ruwvoerdeel van het rantsoen gerekend worden.

De benadering met drie EF-lijsten voldoet ook voor het oudere jongvee dat ruwvoer opneemt, hetgeen aansluit bij de benadering van de KringloopWijzer om voor rantsoenen op veestapelniveau te rekenen. $\mathrm{Er}$ is bij het berekenen van de $\mathrm{CH}_{4}$ emissies op veestapelniveau wellicht een correctie (vermindering) nodig voor jonge kalveren met een rantsoen dat slechts een gering aandeel ruwvoer bevat.

Het is mogelijk om via de receptuur (grondstoffensamenstelling) van mengvoeders de methaanemissie ( $\mathrm{g} / \mathrm{kg}$ ds) van de mengvoeders met ca. $10 \%$ te verminderen. Dat gebeurt via lineaire programmering met een eis voor methaanemissie in $\mathrm{g} / \mathrm{kg}$ product. 
De methaanemissie ( $\mathrm{g} / \mathrm{kg} \mathrm{ds}$ ) van mengvoer verschilt per type mengvoer (standaard, zetmeelrijk en eiwitrijk) en per rantsoensamenstelling op basis van de drie verschillende EF lijsten. Er zijn verschillen geconstateerd variërend van $1 \%$ tot $7 \%$.

De kosteneffectiviteit van het optimaliseren van de methaanemissie van mengvoeders blijkt flink te kunnen verschillen. Het eisenpakket en de striktheid waarmee de eisen worden opgevolgd is sterk bepalend voor de te realiseren kosteneffectiviteit en daarmee voor de meerwaarde als maatregel om de methaanemissie op het melkveebedrijf te verminderen.

\subsection{Mest-handling}

Mest-handling kan de methaanemissie van het gemiddelde Nederlandse melkveebedrijf met ca. 6$18 \%$ verminderen via een reductie van de methaanemissie uit de mestopslag van ca. 30\%-90\% .

De methaanemissie uit mest ( $\mathrm{kg} \mathrm{CO}$ equivalenten per jaar) op het melkveebedrijf wordt bepaald door de hoeveelheid geproduceerde mest, de mestsamenstelling, de mestopslag en het bewerken van de mest. De methaanemissie bij aanwenden is verwaarloosbaar klein.

Vermindering van de methaanemissie uit mest kan gepaard gaan met een toename van de lachgasemissie uit mest. Hierdoor wordt het effect van reductie van de methaanemissie op de totale broeikasgasemissie van het melkveebedrijf gedrukt. Dit effect is echter klein, omdat van de $\mathrm{CO} 2$ equivalenten uit mest slechts ongeveer $4 \%$ van de lachgasemissie komt.

De methaanemissie uit mest ( $\mathrm{kg} \mathrm{CO}$ equivalenten per jaar) op het gemiddelde melkveebedrijf vermindert door over te stappen van een drijfmestsysteem naar een systeem met vaste mest. Mits goed gemanaged is het reductiepotentieel voor de methaanemissie uit mest $60 \%-70 \%$. 


\section{Literatuur}

\section{Rekenregels}

Aarts, H.F.M., Haan, M.H.A. de, Schröder, J.J., Holster H.C., Boer, J.A. de, Reijs, J.W., Oenema, J., Hilhorst G.J., Sebek, L.B., Verhoeven, F.P.M. and Meerkerk, B. (2015). Quantifying the environmental performance of individual dairy farms - the Annual Nutrient Cycling Assessment (ANCA). In: Grassland Science in Europe, Volume 20 pp 377 - 380,

Bannink, A. ; France, J. ; Lopez, S. ; Gerrits, W.J J. ; Kebreab, E. ; Tamminga, S. ; Dijkstra, J. (2008). Modelling the implications of feeding strategy on rumen fermentation and functioning of the rumen wall. Animal Feed Science and Technology 143 (1-4). - p. 3 - 26.

Bannink, A. ; Smits, M.C.J. ; Kebreab, E. ; Mills, J.A.N. ; Ellis, J.L. ; Klop, A. ; France, J. ; Dijkstra, J. (2010). Simulating the effects of grassland management and grass ensiling on methane emission from lactating cows. The J ournal of Agricultural Science 148 . - p. 55 - 72.

Bannink, A. (2011). Methane emissions from enteric fermentation by dairy cows, 1990-2008; Background document on the calculation method and uncertainty analysis for the Dutch National Inventory Report on Greenhouse Gas Emissions. Wageningen, Statutory Research Tasks Unit for Nature and the Environment. WOt werkdocument 265. 63 p.; 8 Fig.; 6 Tab.; 36 Ref.; 2 Annexes.

Bannink, A., M.W. van Schijndel and J. Dijkstra (2011). A model of enteric fermentation in dairy cows to estimate methane emission for the Dutch National Inventory Report using the IPCC Tier 3 approach. Animal Feed Science and Technology 166-167 (2011). - ISSN 0377-8401 - p. 603 - 618.

Bannink, A. ; Warner, D. ; Chuko, B.H. ; St-Pierre, J.L. ; Dijkstra, J. (2016). Quantifying effects of grassland management on enteric methane emission. Animal Production Science 56 (3). - p. 409 416.

BLGG, 2014. Eurofins Agro. Meerjarengemiddelden voor gras- en snijmaiskuilen in Nederland. http://blgg.agroxpertus. nl/gemiddelden

CVB, 2011. Tabellenboek Veevoeding 2011. Uitgave Productschap Diervoeder 2011.

Dijkstra, J. ; Neal, H.D.St.C. ; Beever, D.E. ; France, J. (1992). Simulation of nutrient digestion, absorption and outflow in the rumen: model description. Journal of Nutrition 122 . - p. 2239 2256.

Gerrits, W.J.J. ; Dijkstra, J. ; Bannink, A. (2014). Methaanproductie bij witvleeskalveren. Wageningen : Wageningen UR Livestock, (Rapport 813) - 15 p.

Hatew, B. ; Podesta, S.C. ; Laar, H. van; Pellikaan, W.F. ; St-Pierre, J.L. ; Dijkstra, J. ; Bannink, A. (2015). Effects of dietary starch content and rate of fermentation on methane production in lactating dairy cows. J ournal of Dairy Science 98 (1). - p. 486 - 499.

Hatew, B. ; Bannink, A. ; Laar, H. van; Jonge, L.H. de; Dijkstra, J. (2016). Increasing harvest maturity of whole-plant corn silage reduces methane. Journal of Dairy Science 99 (1). - p. 354 368.

Mills, J. A. N., J. Dijkstra, A. Bannink, S. B. Cammell, E. Kebreab, and J. France. 2001. A mechanistic model of whole-tract digestion and methanogenesis in the lactating dairy cow: Model development, evaluation, and application. J. Anim. Sci. 79:1584.-1597.

Reynolds, C. K., Mills, J. A. N., Crompton, L. A., Givens, D. I. and Bannink, A. (2010) Ruminant nutrition regimes to reduce greenhouse gas emissions in dairy cows. In: Crovetto, G. M. (ed.) Proceedings of the 3rd international symposium on energy and protein metabolism and nutrition. Wageningen Academic Publishers, The Netherlands, pp. 427-437. ISBN 9789086861538

Šebek, L.B., de Haan, M.H.A., Bannink, A., 2014. Methaanemissie op het melkveebedrijf: Impactanalyse voor reductiemaatregelen en doorrekening daarvan in de Kringloopwijzer. Wageningen, Wageningen UR (University \& Research centre) Livestock Research, Livestock Research Rapport 796. 
Schröder, J.J., Šebek, L.B., Reijs, J.W., Oenema, J., Goselink, R.M.A., Conijn, J.G., de Boer, J.M., 2014. Rekenregels van de KringloopWijzer : achtergronden van BEX, BEA, BEP en BEC.

Wageningen, Wageningen UR (University \& Research centre), Plant Research International, rapport 553.

Schröder J.J., L.B. Šebek, J.W. Reijs, J. Oenema, R.M.A. Goselink, J.G. Conijn en J. de Boer. Rekenregels van de KringloopWijzer, actualisatie van de 4 maart 2014 versie. PRI-rapport 640, januari 2016.

Vellinga, Th.V., H. Blonk, H., Marinussen, M., van Zeist, W.J., de Boer, I.J .M., Starmans, D., 2013. Methodology used in FeedPrint: a tool quantifying greenhouse gas emissions of feed production and utilization. Wageningen, Wageningen UR (University \& Research centre) Livestock Research, Livestock Research Rapport 674.

Warner, D. ; Podesta, S.C. ; Hatew, B. ; Klop, G. ; Laar, H. van; Bannink, A. ; Dijkstra, J. (2015). Effect of nitrogen fertilization rate and regrowth interval of grass herbage on methane emission of zero-grazing lactating dairy cows. Journal of Dairy Science 98 (5). - p. 3383 - 3393.

Warner, D. ; Hatew, B. ; Podesta, S.C. ; Klop, G. ; Gastelen, S. van; Laar, H. van; Dijkstra, J. ; Bannink, A. (2016). Effects of nitrogen fertilisation rate and maturity of grass silage on methane emission by lactating dairy cows. Animal 10 (1). - p. 34 - 43.

Zom, R.L.G. (2014). The development of a model for the prediction of feed intake and energy partitioning in dairy cows. PhD Theses internally prepared. Wageningen University 2014. Promotor(en): Wouter Hendriks, co-promotor(en): Ad van Vuuren. - Wageningen : Wageningen University, - $176 \mathrm{p}$.

Zom, R.L.G. ; André, G. ; Vuuren, A.M. van (2012a). Development of a model for the prediction of feed intake by dairy cows: 1. Prediction of feed intake. Livestock Science 143 (1). - p. 43 - 57.

Zom, R.L.G. ; André, G. ; Vuuren, A.M. van (2012b). Development of a model for the prediction of feed intake by dairy cows. 2. Evaluation of prediction accuracy. Livestock Science 143 (1). - p. 58 69.

\section{Mest-handling}

Ambus, P., en S.O. Petersen (2005). Oxidation of 13C-labeled methane in surface crusts of pig- and cattle slurry. I sotopes in Environmental and Health Studies 41, 125-133.

Amon, B., Th. Amon, J. Boxberger, en Ch. Alt (2001). Emissions of $\mathrm{NH}_{3}, \mathrm{~N}_{2} \mathrm{O}$ and $\mathrm{CH}_{4}$ from dairy cows housed in a farmyard manure tying stall (housing, manure storage, manure spreading). Nutrient Cycling in Agroecosystems 60, 103-113.

Amon, B., V. Kryvoruchko, T. Amon en S. Zechmeister-Boltenstern (2006). Methane, nitrous oxide and ammonia emissions during storage and after application of dairy cattle slurry and influence of slurry treatment. Agriculture, Ecosystems and Environment 112, 153-162.

Amon, B., V. Kryvoruchko, M. Fröhlich, T. Amon, A. Pöllinger, I. Mösenbacher en A. Hausleitner (2007). Ammonia and greenhouse gas emissions from a straw flow system for fattening pigs: housing and manure storage. Livestock Science 112, 199-207.

Béline F., J. Martinez, D. Chadwick, F. Guiziou, en C.M. Coste (1999). Factors affecting nitrogen transformations and related nitrous oxide emissions from aerobically treated piggery slurry, J. Agr. Eng. Res. 73, 235-243.

Bertora, C., F. Alluvione, L. Zavattaro, J.W. van Groenigen, G. Velthof, en C. Grignani (2008). Pig slurry treatment modifies slurry composition, N2O, and $\mathrm{CO} 2$ emissions after soil incorporation. Soil Biology \& Biochemistry 40, 1999-2006.

Bjurling, K., en A. Svärd (1998). Co-digestion of organic waste: a study of Swedish biogas plants (in Swedish). Master's Thesis, Department of Water and Environmental Engineering, Lund University Lund, Sweden.

Chadwick, D.R. (2005). Emissions of ammonia, nitrous oxide and methane from cattle manure heaps: effect of compaction and covering. Atmospheric Environment 39, 787-799.

Chadwick, D., S.G. Sommer, R. Thorman, D. Fangueiro, L. Cardenas, B. Amon, en T. Misselbrook (2011). Manure management: implications for greenhouse gas emissions. Animal Feed Science and Technology 166-167, 514-531. 
Chen, Y., J.J. Cheng, en K.D. Creamer (2008). Inhibition of anaerobic digestion process: a review. Bioresource Technology 99, 4044-4064.

Clemens J., en H.J. Ahlgrimm. 2001. Greenhouse gases from animal husbandry: mitigation options. Nutr. Cycl. Agroecosyst. 60, 287-300.

Clemens, J., en A. Huschka (2001). The effect of biological oxygen demand of cattle slurry and soil moisture on nitrous oxide emissions. Nutrient Cycling in Agroecosystems 59, 193-198.

Clemens, J., M. Trimborn, P. Weiland en B. Amon (2006). Mitigation of greenhouse gas emissions by anaerobic digestion of cattle slurry. Agriculture, Ecosystems and Environment 112 (2-3), 171-177.

Coenen, P.W.H.G., C.W.M. van der Maas, P.J. Zijlema, E.J.M.M. Arets, K. Baas, A.C.W.M. van den Berghe, J.D. te Biesebeek, A.T. Brandt, G. Geilenkirchen, K.W. van der Hoek, R. te Molder, R. Dröge, J.A. Montfoort, C.J. Peek, en J. Vonk (2013). Greenhouse gas emissions in The Netherlands 1990-2011. National Inventory Report 2013. RIVM Report 680355013/2013.

Dinuccio, E., W. Berg, en P. Balsari (2008). Gaseous emissions from the storage of untreated slurries and the fractions obtained alter mechanical separation. Atmospheric Environment 42, 2448-2459.

Edouard, N., A. Charpiot, M. Hassouna, P. Faverdin, P. Robin, en J.B. Dollé. 2012. Ammonia and greenhouse gases emissions from dairy cattle buildings: slurry vs. farm yard manure management systems. International Symposium on Emission of Gas and Dust from Livestock. INRA, Saint-Malo, France.

Fangueiro, D., J. Coutinho, D. Chadwick, N. Moreira, en H. Trindade (2008a). Effect of cattle slurry separation on greenhouse gas and ammonia emissions during storage. J. Environ. Qual. 37, 23222331.

Fangueiro, D., M. Senbayran, H. Trindade, en D. Chadwick (2008b). Cattle slurry treatment by screw press separation and chemically enhanced settling: effect on greenhouse gas emissions alter land spreading and grass yield. Bioresource Technology 99, 7132-7142.

Gerber, P.J., A. N. Hristov, B. Henderson, H. Makkar, J. Oh, C. Lee, R. Meinen, F. Montes, T. Ott, J. Firkins, A. Rotz, C. Dell, A.T. Adesogan, W.Z. Yang, J.M. Tricarico, E. Krebeab, G. Waghorn, J . Dijkstra, en S. Oosting (2013). Technical options for the mitigation of direct methane and nitrous oxide emissions from livestock: a review. Animal 7, 220-234.

Groenestein, C.M. (2006). Environmental aspects of improving sow welfare with group housing and straw bedding. PhD thesis, Wageningen University, Wageningen, The Netherlands.

Groenestein, G.M., J.F.M. Huijsmans, en R.L.M. Schils (2010). Emissies van broeikasgassen, ammoniak, fijn stof en geur in de mestketen. Rapport 248.

Groenestein, C.M., J. Mosquera en S.M. van der Sluis (2012). Emission factors for methane and nitrous oxide from manure management and mitigation options. Submitted to J ournal of Integrative Environmental Sciences.

Guarino, M., C. Fabbri, M. Brambilla, L. Valli, en P. Navarotto (2006). Evaluation of simplified covering systems to reduce gaseous emissions from livestock manure storage. Transactions of the ASABE 49(3), 737-747.

Haeussermann, A., E. Hartung, E. Gallmann en T. J ungbluth (2006). Influence of season, ventilation strategy, and slurry removal on methane emissions from pig houses. Agriculture, Ecosystems and Environment 112, 115-121.

Hansen, R.R., D.A. Nielsen, A. Schramm, L.P. Nielsen, N.P. Revsbech, en M.N. Hansen (2009). Greenhouse gas microbiology in wet and dry straw crust covering pig slurry. Journal of Environmental Quality 38, 1311-1319.

Hao, X., C. Chang, F.J. Larney, en G.R. Travis (2001). Greenhouse gas emissions during cattle feedlot manure composting. J. Environ. Qual. 30, 376-386.

Hao, X.Y., F.J . Larney, C. Chang, G.R. Travis, C.N. Nichol, en E. Bremer (2005). The effect of phosphogypsum on greenhouse gas emissions during cattle manure composting. J. Environ. Qual. 34, 774-781.

Hassouna, M., P. Robin, A. Brachet, J.M. Paillat, J.B. Dolle, P. Faverdin. 2010. Development and validation of a simplified method to quantify gaseous emissions from cattle buildings. In Proceedings of the XVII World Congress of the International Commission of Agricultural Engineerinhg (CIGR), Québec City, Canada, 13-17 J une 2010.

Hindrichsen, I.K., H.R. Wettstein, A. Machmüller, B. Jörg, en M. Kreuzer (2005). Effect of the carbohydrate composition of feed concentrates on methane emissions from dairy cows and their slurry. Environmental Monitoring and Assessment 107, 329-350. 
Hristov A.N., K. Heyler, E. Schurman, K. Griswold, P. Topper, M. Hile, V. Ishler, E. Wheeler, en S. Dinh. 2012. Reducing dietary protein decreased the ammonia emitting potential of manure from commercial dairy farms. Journal of Dairy Science 95 (Suppl. 2), 477.

Husted, S. 1994. Seasonal variation in methane emission from stored slurry and solid manures. J. Environ. Qual. 23, 585-592.

IPCC (2006). 2006 IPCC Guidelines for National Greenhouse Gas Inventories.

Jiang T., F. Schuchardt, G. Li, R. Guo, en Y. Zhao (2011). Effect of C/N ratio, aeration rate and moisture content on ammonia and greenhouse gas emission during the composting. Journal of Environmental Sciences (China) 23, 1754- 1760.

J un, P., M. Gibbs, en K. Gaffney (1999). Methane and nitrous oxide emissions from livestock manure. Background report for expert group meeting on good practice in inventory preparation for agricultural sources of methane and nitrous oxide. 24-26 February, Wageningen, The Netherlands.

Külling, D.R., H. Menzi, T. F. Kröber, A. Neftel, F. Sutter, P. Lischer, en M. Kreuzer (2001). Emissions of ammonia, nitrous oxide and methane from different types of dairy manure during storage as affected by dietary protein content. Journal of Agricultural Science 137, 235-250.

Lin, C.Y., F.Y. Chang, en C.H. Chang (2001). Toxic effect of sulfur compounds on anaerobic biogranulate. J. Hazard. Mater. A87, 11-21.

Lopez-Real, J., en M. Baptista (1996). A preliminary comparative study of three manure composting systems and their influence on process parameters and methane emissions. Compost Science and Utilization 4, 371-382.

Loyon L., F. Guiziou, E. Beline, en P. Peu (2007). Gaseous emissions (NH3, N2O, CH4 and CO2) from the aerobic treatment of piggery slurry-comparison with a conventional storage system. Biosystems Engineering 97, 472-480.

Mangino, J., D. Bartram, en A. Brazy (2001). Development of a methane conversion factor to estimate emissions from animal waste lagoons. Presented at U.S. EPA's 17th Annual Emission Inventory Conference, Atlanta GA, April 16-18, 2002.

Martinez, J., F. Guiziou, P. Peu, en V. Gueutier (2003). Influence of treatment techniques for pig slurry on methane emissions during subsequent storage. Biosystems Engineering 85(3), 347-354.

Misselbrook, T.H., S.K.E. Brookman, K.A. Smith, T. Cumby, A.G. Williams, en D.F. McCrory (2005). Crusting of stored dairy slurry to abate ammonia emissions: pilot-scale studies. J ournal of Environmental Quality 34(2), 411-419.

Molodovskaya, M. S., O. Singurindy, B.K. Richards, en T.S. Steenhuis (2008). Nitrous oxide emissions from dairy manure as affected by oxic and anoxic conditions. Bioresource Technol. 99, 8643-8648.

Mosquera, J., J.M.G. Hol, en J.W.H. Huis in 't Veld (2005). Onderzoek naar de emissies van een natuurlijk geventileerde potstal voor melkvee. I. Stal. A\&F Rapport 324.

Mosquera, J., R. Schils, K. Groenestein, P. Hoeksma, G. Velthof, en E. Hummelink (2011). Emissies van lachgas, methaan en ammoniak uit mest na scheiding. Wageningen UR Livestock Research Report 427.

Myhre, G., D. Shindell, F.-M. Bréon, W. Collins, J. Fuglestvedt, J. Huang, D. Koch, J.-F. Lamarque, D. Lee, B. Mendoza, T. Nakajima, A. Robock, G. Stephens, T. Takemura, en H. Zhang (2013). Anthropogenic and Natural Radiative Forcing. In: Climate Change 2013: The Physical Science Basis. Contribution of Working Group I to the Fifth Assessment Report of the Intergovernmental Panel on Climate Change [Stocker, T.F., D. Qin, G.-K. Plattner, M. Tignor, S.K. Allen, J. Boschung, A. Nauels, Y. Xia, V. Bex, en P.M. Midgley (eds.)]. Cambridge University Press, Cambridge, United Kingdom and New York, NY, USA.

Nielsen, D., A. Schramm, en N. Revsbech (2010). Oxygen distribution and potential ammonia oxidation in floating liquid manure crusts. Journal of Environmental Quality 39, 1813-1820.

Osada, T., K. Kuroda, en M. Yonaga (2000). Determination of nitrous oxide, methane, and ammonia emissions from a swine waste composting process. Journal of Material Cycles and Waste Management 2, 51-56.

Pattey, E., M.K. Trzcinski, en R.L. Desjardins (2005). Quantifying the reduction of greenhouse gas emissions as a result of composting dairy and beef cattle manure. Nutrient Cycling in Agroecosystems 72, 173-187.

Petersen, S.O., B. Amon, en A. Gattinger (2005). Methane oxidation in slurry storage surface crusts. Journal of Environmental Quality 34, 455-461. 
Petersen, S.O., A.J. Andersen, en J. Eriksen (2012). Effects of slurry acidification on ammonia and methane emission during storage. Journal of Environmental Quality 41, 88-94.

Petersen, S.O., O. Hojberg, M. Poulsen, C. Schwab, en J. Eriksen (2014). Methanogenic community changes, and emissions of methane and other gases, during storage of acidified and untreated pig slurry. J ournal of Applied Microbiology 117(1), 160-172.

Šebek, L.B., de Haan, M.H.A., Bannink, A., 2014. Methaanemissie op het melkveebedrijf: Impactanalyse voor reductiemaatregelen en doorrekening daarvan in de Kringloopwijzer. Wageningen, Wageningen UR (University \& Research centre) Livestock Research, Livestock Research Rapport 796.

Smith, K., T. Cumby, J. Lapworth, T. Misselbrook, en A. Williams (2007). Natural crusting of slurry storage as an abatement measure for ammonia emissions on dairy farms. Biosystems Engineering 97, 464-471.

Sommer, S.G., S.O. Petersen en H.T. Sogaard (2000). Greenhouse gas emission from stored livestock slurry. J. Environ. Qual. 29, 744-751.

Sommer S.G., H.B. Møller, en S.O. Petersen (2001). The reduction of greenhouse gases from manure and organic waste using digestion and biogas production (in Deens). Danmarks JordbrugsForskning, Denmark.

Sommer, S.G., B.T. Christensen, N.E. Nielsen, en J.K. Schjøring (1993). Ammonia volatilization during storage of cattle and pig slurry: effect of surface cover. J ournal of Agricultural Science 121, 63-71

Sommer, S.G., S.O. Petersen, en H.B. Møller (2004). Algorithms for calculating methane and nitrous oxide emissions from manure management. Nutrient Cycling in Agroecosystems 69, 143-154.

Sommer, S.G., J.E. Olesen, S.O. Petersen, M.R. Weisbjerg, L. Valli, L. Rohde, en F. Béline (2009). Region-specific assessment of greenhouse gas mitigation with different manure management strategies in four agroecological zones. Global Change Biology 15, 2825-2837.

Szanto, G.L., H.V.M. Hamelers, W.H. Rulkens, en A.H.M. Veeken (2007). NH3, N2O and CH4 emissions during passively aerated composting of straw-rich pig manure. Bioresource Technology 98, 2659-2670.

Tao, J., F. Schuchardt, L. GuoXue, G. Rui, en Z. YuanQiu (2011). Effect of C/N ratio, aeration rate and moisture content on ammonia and greenhouse gas emission during the composting. J. Environ. Sci. 23, 1754-1760.

Thompson A.G., C. Wagner-Riddle, en R. Fleming (2004). Emissions of N2O and CH4 during the composting of liquid swine manure. Environmental Monitoring and Assessment 91, 87-104.

Umetsu, K., Y. Kimura, J. Takahashi, T. Kishimoto, T. Kojima, en B. Young (2005). Methane emission from stored dairy manure slurry and slurry after digestion by methane digester. Animal Science Journal 76, 73-79.

Van der Zaag, A.C., R. Gordon, V. Glass, en R. Jamieson (2008). Floating covers to reduce gas emissions from liquid manure storages: a review. Applied Engineering in Agriculture 24, 657-671.

Van der Zaag, A.C., R.J. Gordon, R.C. Jamieson, D.L. Burton en G.W. Stratton (2009). Gas emissions from straw covered liquid dairy manure during summer storage and autumn agitation. Transactions of the ASABE 52(2), 599-608.

Webb, J., S.G. Sommer, T. Kupper, K. Groenestein, N.J. Hutchings, B.Eurich-Menden, L. Rodhe, T.H. Misselbrook, and B. Amon. 2012. Emissions of ammonia, nitrous oxide and methane during the management of solid manures. Sustainable Agriculture Reviews 8, 67-107.

Willers, H.C., P.J.L. Derikx, P.J.W. ten Have, en T.K. Vijn (1996). Emission of ammonia and nitrous oxide from aerobic treatment of veal calf slurry. J. Agr. Eng. Res. 63, 345-352.

Wulf, S., M. Maeting, en J. Clemens (2002). Application technique and slurry co-fermentation effects on ammonia, nitrous oxide and methane emissions after spreading. II. Greenhouse gas emissions. J ournal of Environmental Quality 31, 1795-1801.

Yamulki, S. (2006). Effect of straw addition on nitrous oxide and methane emissions from stored farmyard manures. Agriculture, Ecosystems and Environment 112, 140-145. 


\section{Bijlage 1}

Lijst met emissiefactoren voor enterische $\mathrm{CH}_{4}$ (EF in $\mathrm{g} \mathrm{CH}_{4}$ per $\mathrm{kg}$ ds grondstof), voor rantsoenen met in het ruwvoerdeel van het rantsoen respectievelijk $0 \%, 40 \%$ en $80 \%$ snijmais op basis van droge stof. ${ }^{*}$ Cursieve gegevens zijn geschat op basis van verteerbaarheid en een hoog aandeel NDF in de ds (de verschillende soorten stro) en op basis van het overeenkomstige meel van dat ruwvoeder (luzerne).

$\mathrm{g} \mathrm{CH}_{4} / \mathrm{kg}$ DS grondstof

$0 \%$ snijmais $40 \%$ snijmais $80 \%$ snijmais

\begin{tabular}{|c|c|c|c|}
\hline Graskuil & 19,5 & 19,5 & 21,0 \\
\hline maiskuil & 18,4 & 17,5 & 16,2 \\
\hline Tarwe/gerste/graszaad/koolzaadstro & & $17^{*}$ & \\
\hline Luzerne & & $20^{*}$ & \\
\hline Bietpulp SUI < 100 & 25,2 & 25,6 & 28,5 \\
\hline Sojahullen RC > 360 & 23,8 & 23,4 & 24,0 \\
\hline Tarwe & 23,4 & 23,0 & 22,5 \\
\hline Gerst & 22,8 & 22,1 & 20,7 \\
\hline Mais & 21,2 & 19,7 & 17,8 \\
\hline Palmpitschilfers RC $<220$ & 17,0 & 17,4 & 18,5 \\
\hline Palmpitschilfers RC > 220 & 16,7 & 17,4 & 18,6 \\
\hline Raapschroot RE $<380$ & 18,7 & 19,3 & 22,8 \\
\hline Sojaschroot RC 50-70 RE > 440 & 21,2 & 20,6 & 22,5 \\
\hline Zonnebloemzaadschroot RC $<160$ & 19,2 & 19,5 & 22,4 \\
\hline Sojaschroot MervoBest & 20,6 & 19,4 & 19,0 \\
\hline Lupinen $\mathrm{RV}<70 \mathrm{RE}>335$ & 20,8 & 20,5 & 22,2 \\
\hline Tarwegries & 20,4 & 20,6 & 22,0 \\
\hline Maisglutenvoer RE 200-230 & 20,3 & 19,8 & 19,4 \\
\hline Aardappelvezel $\mathrm{RE}<95$ & 22,0 & 21,6 & 20,8 \\
\hline Aardappelvezel RE 95-140 & 21,3 & 20,9 & 20,1 \\
\hline Aardappelzetmeel gedr, & 24,0 & 22,3 & 20,2 \\
\hline Aardappelchips & 12,1 & 12,3 & 11,4 \\
\hline Aardappeleiwit RAS <10 & 16,5 & 14,8 & 14,0 \\
\hline Aardappeleiwit RAS>10 & 16,3 & 14,7 & 14,0 \\
\hline Aardappelen gedroogd & 22,7 & 21,5 & 20,5 \\
\hline Bataten gedroogd & 24,6 & 23,6 & 22,1 \\
\hline Bierbostel gedroogd & 16,7 & 16,4 & 16,3 \\
\hline Biergist gedroogd & 19,7 & 18,6 & 18,6 \\
\hline Bietenpulp SUI >200 & 26,3 & 26,0 & 28,1 \\
\hline Bietenpulp SUI 100-150 & 25,6 & 25,8 & 28,5 \\
\hline Bonen (phas) verhit & 21,3 & 20,9 & 21,4 \\
\hline Broodmeel & 23,0 & 23,5 & 23,2 \\
\hline Caseine & 18,3 & 16,7 & 16,8 \\
\hline Cichoreipulp gedroogd & 25,0 & 25,2 & 27,9 \\
\hline Citruspulp & 27,0 & 26,4 & 28,0 \\
\hline Erwten droog & 22,8 & 22,0 & 22,1 \\
\hline Gersteslijpmeel & 19,7 & 19,2 & 18,7 \\
\hline Gerstevoermeel & 19,1 & 18,6 & 18,1 \\
\hline Grasmeel RE<160 & 20,4 & 20,2 & 21,0 \\
\hline Grasmeel RE>200 & 19,6 & 19,4 & 20,1 \\
\hline
\end{tabular}


Grasmeel RE 160-200

Graszaad

Grondnootschillen ged, ontd,

Grondnootschillen niet ontdopt

Grondnootschillen ontdopt

Grondnootschroot ged, ontd,

Grondnootschroot ontdopt

Grondnoot niet ontd,

Grondnoot

Haver

Haver gepeld

Havermout afvalmeel

Havervoermeel

Hennepzaad

J ohannesbrood

Katoenzaadschillen ged, ontdopt

Katoenzaadschillen

Katoenzaadschillen ontdopt

Katoenzaadschroot ged, Ontdopt

Katoenzaadschroot niet ontdopt

Katoenzaadschroot ontdopt

Katoenzaad niet ontd

Katoenzaad ontdopt

Kokosschroot

Kokosschilfers RV $<100$

Kokosschilfers RV $>100$

Lijnzaad

Lijnzaadschilfers

Lijnzaadschroot

Linzen

Lupinen $\mathrm{RV}<70 \mathrm{RE}<335$

Luzernemeel $\mathrm{RE}<140$

Luzernemeel RE $>180$

Luzernemeel RE 140-160

Mais ontsloten

Maisglutenmeel

Maisglutenvoermeel $\mathrm{RE}<200$

Maisglutenvoermeel RE $>230$

Maiskiemschilfers

Maiskiemschroot

Maiskiemzemelschilfers

Maiskiemzemelschroot

Maisspoeling gedroogd

Maisvoerbloem

Maisvoermeel

Maisvoerschroot

Maiszemelgrint

Maiszetmeel

Melasse riet SUI $<475$

Melasse riet SUI $>475$
20,2

19,9

20,6

22,3

21,5

19,9

17,6

17,7

20,0

14,1

14,7

17,2

18,0

18,0

20,1

17,8

18,0

20,3

21,0

20,8

23,3

8,4

9,1

11,5

3,6

4,0

5,6

19,7

19,8

19,8

21,1

20,8

20,4

17,3

17,8

18,1

18,9

19,2

19,4

9,9

10,0

11,3

27,2

26,0

26,4

15,9

15,9

17,4

15,8

16,0

17,6

13,9

14,0

15,4

17,5

17,7

19,9

18,0

18,2

20,3

17,4

17,4

19,5

17,8

16,8

16,9

10,4

10,1

11,3

20,8

21,2

23,2

18,7

19,1

20,9

17,0

17,5

19,4

8,6

9,0

10,7

18,4

18,6

21,0

20,6

20,6

23,2

22,3

20,9

19,8

21,9

21,5

23,2

20,9

21,1

22,5

19,7

19,8

21,2

19,8

20,0

21,5

22,6

22,9

21,2

16,6

15,2

13,3

20,6

20,0

19,5

20,1

19,5

19,2

19,0

18,9

19,7

21,1

21,5

23,7

20,2

19,8

20,1

21,2

21,5

23,5

19,4

20,0

22,9

23, 1

21,5

19,3

20,7

19,6

18,1

22,4

21,4

20,5

22,1

21,4

20,5

23,9

22,0

22,7

29,6

22,0

22,7

30,0

22,1

19,6 


\begin{tabular}{|c|c|c|c|}
\hline Melasse biet & 30,0 & 28,7 & 30,7 \\
\hline Melkpoeder mager & 25,6 & 28,8 & 30,1 \\
\hline Melkpoeder vol & 16,5 & 15,2 & 14,5 \\
\hline Mervobest Raap & 17,9 & 17,9 & 18,6 \\
\hline Millet (Gierst) & 20,8 & 19,5 & 17,6 \\
\hline Millet Bullrush & 21,0 & 18,0 & 16,9 \\
\hline Moutkiemen $\mathrm{RE}<200$ & 21,6 & 21,3 & 21,4 \\
\hline Moutkiemen RE>200 & 21,6 & 20,2 & 21,6 \\
\hline Nigerzaad & 7,6 & 7,3 & 7,6 \\
\hline Paardebonen Bontbl & 22,0 & 21,6 & 22,9 \\
\hline Paardebonen Witbl & 21,9 & 21,4 & 22,6 \\
\hline Palmpitschroot & 19,7 & 20,8 & 23,5 \\
\hline Palmpitten & 2,7 & 3,6 & 4,4 \\
\hline Raapschroot RE>380 & 19,0 & 19,4 & 22,6 \\
\hline Raapzaad onbehandeld & 4,9 & 5,7 & 7,9 \\
\hline Raapzaadschilfers & 17,5 & 17,9 & 20,9 \\
\hline Rijst met dop & 18,8 & 18,1 & 17,0 \\
\hline Rijst ontdopt & 22,7 & 21,3 & 19,7 \\
\hline Rijstafvallen & 12,0 & 12,4 & 12,2 \\
\hline Rijstevoerschroot & 15,9 & 15,6 & 15,1 \\
\hline Rijstvoermeel RAS <90 & 14,1 & 13,7 & 12,9 \\
\hline Rijstvoermeel RAS>90 & 12,5 & 12,2 & 11,6 \\
\hline Rogge & 23,7 & 23,3 & 22,9 \\
\hline Roggegries & 20,1 & 20,4 & 22,1 \\
\hline Saffloerzaad & 7,7 & 8,9 & 11,6 \\
\hline \multicolumn{4}{|l|}{ Saffloerzaadschroot } \\
\hline Sesamzaad & 6,6 & 6,7 & 7,9 \\
\hline Sesamzaadschilfers & 15,4 & 15,0 & 16,2 \\
\hline Sesamzaadschroot & 21,5 & 20,7 & 21,9 \\
\hline Sojabonen verhit & 15,1 & 15,0 & 17,3 \\
\hline Sojabonen niet verhit & 15,3 & 15,3 & 17,5 \\
\hline Sojahullen $\mathrm{RC}<320$ & 22,8 & 22,40 & 23,0 \\
\hline Sojahullen RC 320-360 & 23,4 & 23,01 & 23,6 \\
\hline Sojaschilfers & 18,4 & 18,15 & 20,3 \\
\hline Sojaschroot Rumi S & 20,3 & 19,12 & 18,7 \\
\hline \multicolumn{4}{|l|}{ Sojaschroot SoyPass } \\
\hline Sojaschroot RC<50 & 21,0 & 20,40 & 22,3 \\
\hline Sojaschroot RC>70 & 21,1 & 20,51 & 22,3 \\
\hline Sojaschroot RC 50-70 RE $<440$ & 21,2 & 20,60 & 22,4 \\
\hline Sorghum & 21,2 & 19,76 & 17,9 \\
\hline Sorghumglutenmeel & 18,3 & 17,29 & 16,2 \\
\hline Suiker & 34,1 & 31,06 & 28,5 \\
\hline Tapioca ZET 575-625 & 23,9 & 23,24 & 22,3 \\
\hline Tapioca ZET 625-675 & 23,9 & 23,07 & 21,8 \\
\hline Tapioca ZET 675-725 & 24,0 & 23,14 & 21,8 \\
\hline Tapiocazetmeel & 24,9 & 23,43 & 20,9 \\
\hline Tarweglutenmeel & 17,0 & 15,74 & 16,2 \\
\hline Tarweglutenvoer gedroogd & 20,8 & 20,35 & 19,8 \\
\hline Tarwekiemen & 19,3 & 19,23 & 20,6 \\
\hline Tarwekiemzemelen & 20,6 & 20,60 & 21,6 \\
\hline Tarwevoerbloem $\mathrm{RC}<=35$ & 22,2 & 21,97 & 22,0 \\
\hline
\end{tabular}




\begin{tabular}{|c|c|c|c|}
\hline Tarwevoerbloem RC 35-55 & 21,6 & 21,60 & 22,2 \\
\hline Tarwevoermeel & 20,9 & 20,92 & 22,1 \\
\hline Tarwezemelgrint & 20,2 & 20,30 & 21,7 \\
\hline Triticale & 23,6 & 23,29 & 23,1 \\
\hline Vet dierlijk & $-11,7$ & $-10,94$ & $-11,2$ \\
\hline Vet/olie plant hg VC & $-11,8$ & $-10,95$ & $-11,2$ \\
\hline Vet/olie plant Ig VC & $-11,8$ & $-10,95$ & $-11,2$ \\
\hline Vinasse $R E<250$ & 21,5 & 22,69 & 27,1 \\
\hline Vinasse RE > 250 & 22,0 & 22,91 & 27,0 \\
\hline Weiproducten MSA RAS $<210$ & 22,9 & 21,91 & 22,9 \\
\hline Weiproducten MSA RAS > 210 & 22,6 & 21,62 & 22,6 \\
\hline Weipoeder & 29,6 & 27,83 & 28,0 \\
\hline Zonnebloedzaadschilfers ged, Ontdopt & 14,0 & 14,61 & 17,1 \\
\hline Zonnebloemzaadschilfers niet ontdopt & 9,8 & 10,68 & 12,6 \\
\hline Zonnebloemzaadschilfers ontdopt & 16,7 & 17,10 & 19,9 \\
\hline Zonnebloemzaadschroot RC $>240$ & 16,9 & 17,44 & 20,0 \\
\hline Zonnebloemzaadschroot RC 160-200 & 18,1 & 18,66 & 21,7 \\
\hline Zonnebloemzaadschroot RC 200-240 & 17,5 & 18,00 & 20,8 \\
\hline Zonnebloemzaad ged, Ontdopt & 7,1 & 7,99 & 10,1 \\
\hline Zonnebloemzaad niet ontdopt & 4,6 & 5,57 & 7,0 \\
\hline Zonnebloemzaad ontdopt & 6,5 & 6,66 & 8,3 \\
\hline Aardappelsnippers rauw & 22,2 & 21,17 & 20,5 \\
\hline Aardappelstoomschillen ZET $<350$ & 22,7 & 24,99 & 29,7 \\
\hline Aardappelstoomschillen ZET>600 & 23,7 & 24,74 & 26,6 \\
\hline Aardappelstoomschillen ZET 350-475 & 23,0 & 25,01 & 28,9 \\
\hline Aardappelstoomschillen ZET 475-600 & 23,5 & 24,88 & 27,5 \\
\hline Aardappeldiksap & 20,1 & 21,72 & 26,7 \\
\hline Aardappelpersvezel vers+kuil & 21,4 & 21,68 & 23,4 \\
\hline Aardappelzetmeel niet onsloten stkv & 22,9 & 21,36 & 19,2 \\
\hline Aardappelzetmeel ZET 500-650 & 22,2 & 21,14 & 20,1 \\
\hline Aardappelzetmeel ZET 650-775 & 22,5 & 21,27 & 19,8 \\
\hline Aardappelzetmeel ZET>775 & 23,0 & 21,52 & 19,7 \\
\hline Bierbostel $22 \%$ DS vrs & 15,8 & 15,59 & 15,4 \\
\hline Bierbostel, persbostel & 15,6 & 15,43 & 15,6 \\
\hline Bietenperspulp vers+kuil & 24,6 & 24,53 & 26,2 \\
\hline CCM kuil deel spil & 20,5 & 19,14 & 17,3 \\
\hline CCM kuil met spil & 20,5 & 19,36 & 17,5 \\
\hline CCM kuil zonder spil & 20,5 & 19,17 & 17,3 \\
\hline Cichorei perspulp vers+kuil & 24,8 & 24,49 & 25,7 \\
\hline Kaaswei RE<175 & 27,9 & 27,15 & 29,4 \\
\hline Kaaswei RE>275 & 25,0 & 25,54 & 29,9 \\
\hline Kaaswei RE 175-275 & 26,5 & 26,67 & 30,6 \\
\hline Maisglutenvoer vers+kuil & 21,0 & 20,16 & 19,1 \\
\hline Maisweekwater & 22,0 & 23,32 & 28,5 \\
\hline Wortelstoomschillen vers & 24,7 & 23,93 & 24,7 \\
\hline
\end{tabular}




\section{Bijlage 2}

Bijlage 2a, Resultaat basisoptimalisatie voor productiebrok (geen restrictie voor methaanemissie)

\begin{tabular}{|c|c|c|c|c|c|c|c|c|c|}
\hline \multicolumn{2}{|c|}{ BESTMIX TM } & & & & & & \multirow{2}{*}{\multicolumn{3}{|c|}{\begin{tabular}{|r|} 
Kostenformulier \\
$27-05-2015-16: 45$ \\
\end{tabular}}} \\
\hline \multirow{3}{*}{$\begin{array}{l}\text { Product } \\
\text { Fabriek }\end{array}$} & & & & & & & & & \\
\hline & 1121.71 F4F & \multicolumn{2}{|c|}{ Productiebrok 940-105-10 F4F } & & Versie & 2 & \multicolumn{2}{|c|}{ (Productnummer } & \multirow[t]{2}{*}{$3366)$} \\
\hline & & & & & Diergroep & \multicolumn{2}{|c|}{ Melkkoeien } & & \\
\hline Prijslijst & rundveevoeder & 201505 & & & & & & & \\
\hline Ingrediënt & & & Prijs $\left(€^{*} 1\right.$ & $00 / 100 \mathrm{~kg})$ & perc. & & Gewicht (kg) & Prijs & \\
\hline 31020 & Sojahulln RC 320 & -360 & & 13,25 & 20,000 & & 20,000 & 2,650 & $€ \star 100$ \\
\hline 37040 & Bietpulp SUI $>200$ & & & 15,75 & 17,985 & & 17,985 & 2,833 & $€ \star 100$ \\
\hline 11200 & Mais & & & 17,45 & 12,100 & & 12,100 & 2,111 & $€ \star 100$ \\
\hline 21200 & Tarweglutenvoer $\mathrm{g}$ & gedr uit NPL & & 15,60 & 10,000 & & 10,000 & 1,560 & $€ * 100$ \\
\hline 21400 & Sojaschrt Mervobe & est & & 40,10 & 5,612 & & 5,612 & 2,250 & $€ * 100$ \\
\hline 27210 & Zonblosr RC $<16$ & 60 (RE380) & & 25,10 & 5,391 & & 5,391 & 1,353 & $€ * 100$ \\
\hline 37610 & Vinasse $R E<250$ & & & 9,50 & 4,000 & & 4,000 & 0,380 & $€ * 100$ \\
\hline 00913 & Zout & & & 14,00 & 0,271 & & 0,271 & 0,038 & $€ * 100$ \\
\hline & & & & 17,05 & 100,000 & & 100,000 & 17,047 & $€ * 100$ \\
\hline Analyse & & & & & & & & & \\
\hline Code & Omschrijving & Waarde & Eenheid & Code & Omschrijvi & & & Waarde & Eenhe \\
\hline Weende Anal & lyse & & & 115 & DVMETh & & & 2,245 & $g$ \\
\hline 1 & DS & 884,828 & $\mathrm{~g}$ & 27 & FOSp & & & 471,370 & $\mathrm{~g}$ \\
\hline 111 & DSref & 884,828 & $\mathrm{~g}$ & 144 & FOSp-2 & & & 210,370 & $\mathrm{~g}$ \\
\hline 200 & GEWICHT & 100,000 & $\mathrm{~g}$ & 380 & Kok. s+s & & & & $\%$ \\
\hline 112 & OK & 405,969 & $\mathrm{~g}$ & 379 & Kok+Palm & & & 20,000 & $\%$ \\
\hline 133 & $\mathrm{OKh}$ & 194,180 & $\mathrm{~g}$ & 415 & Maïs gluten & voerP & & & $\%$ \\
\hline 2 & RAS & 74,016 & $\mathrm{~g}$ & & ROD & & & & \\
\hline & & & & 416 & P/RE & & & 2,209 & $\%$ \\
\hline Mineralen & & & & & & & & & \\
\hline & & & & 408 & PalmpitPR & OD & & 20,000 & $\%$ \\
\hline 11 & $\mathrm{Ca}$ & 6,000 & $\mathrm{~g}$ & & & & & & \\
\hline & & & & 374 & Peulvr & & & & $\%$ \\
\hline $11 / 12$ & $\mathrm{Ca} / \mathrm{P}$ & 1,634 & g & & & & & & \\
\hline & & & & 378 & Pulp & & & 17,985 & $\%$ \\
\hline 16 & $\mathrm{Cl}$ & 3,354 & $\mathrm{~g}$ & & & & & & \\
\hline & & & & 381 & Raapprod & & & & $\%$ \\
\hline 14 & $\mathrm{~K}$ & 14,347 & g & & & & & & \\
\hline & & & & $3 / 1$ & $\mathrm{RE} / \mathrm{kg} \mathrm{DS}$ & & & 187,843 & $\mathrm{~g}$ \\
\hline 13 & $\mathrm{Mg}$ & 5,071 & $\mathrm{~g}$ & & & & & & \\
\hline & & & & 140 & RNSP & & & 111,042 & $g$ \\
\hline 15 & $\mathrm{Na}$ & 2,500 & g & & & & & & \\
\hline & & & & 401 & RVET_com & pleet & & 36,000 & $\mathrm{~g}$ \\
\hline 12 & $\mathrm{P}$ & 3,671 & $\mathrm{~g}$ & & & & & & \\
\hline & & & & 370 & Su+onbZm & & & 170,377 & $\mathrm{~g}$ \\
\hline Runderen & & & & 116 & SW & & & 86,287 & $\mathrm{~kg}$ \\
\hline 9 & ADF & 200,723 & $\mathrm{~g}$ & 373 & Tarweprod & & & 10,000 & $\%$ \\
\hline 10 & $\mathrm{ADL}$ & 24,678 & $\mathrm{~g}$ & 25 & VEM & & & 940,000 & $\mathrm{~kg}$ \\
\hline 382 & Bestprod & 5,612 & $\%$ & $25 / 1$ & VEM/DS & & & $1.062,354$ & - \\
\hline 130 & BZET & 28,145 & $\mathrm{~g}$ & 402 & VertCOefR & & & 67,482 & $\%$ \\
\hline 404 & DVE_1991 & 105,000 & $\mathrm{~g}$ & 400 & VREherk & & & 127,749 & $\mathrm{~g}$ \\
\hline 28 & DVE-2007 & 106,733 & $\mathrm{~g}$ & 131 & $\mathrm{~W}$ & & & 0,284 & $\mathrm{~kg}$ \\
\hline
\end{tabular}


Bijlage 2b, Resultaat basisoptimalisatie voor eiwitbrok (geen restrictie voor methaanemissie)

\begin{tabular}{|c|c|c|c|c|c|c|c|c|c|c|}
\hline \multirow{2}{*}{\multicolumn{3}{|c|}{ BESTMIX TM }} & & & & & & \multirow{2}{*}{\multicolumn{3}{|c|}{$\begin{array}{r}\text { Kostenformulier } \\
28-05-2015-08: 45 \\
\end{array}$}} \\
\hline & & & & & & \multirow{3}{*}{$\begin{array}{r}\text { Versie } \\
\text { Diergroep }\end{array}$} & & & & \\
\hline \multirow{2}{*}{$\begin{array}{l}\text { Product } \\
\text { Fabriek }\end{array}$} & \multicolumn{2}{|c|}{ 1121.74 F4F } & \multicolumn{3}{|c|}{ Zeer eiwitrijke brok 940-180-90 F4F } & & 4 & \multicolumn{2}{|c|}{ (Productnummer } & \multirow[t]{2}{*}{ 3377) } \\
\hline & & & & & & & \multicolumn{2}{|c|}{ Melkkoeien } & & \\
\hline Omschrijvin & & Melkvee zeer & eiwitrijke brok 940 & $-180-90 \mathrm{~F} 4$ & MVV8 - Eiv & orok & & & & \\
\hline Prijslijst & & rundveevoeder & r201505 & & & & & & & \\
\hline Ingrediënt & & & & Prijs(€ & $00 / 100 \mathrm{~kg})$ & perc. & & Gewicht (kg) & Prijs & \\
\hline 30922 & & jasr RC50-70R & $\mathrm{E}>450$ & & 37,60 & 29,481 & & 29,481 & 11,085 & $€ \star 100$ \\
\hline 26410 & & Impitschilf $\mathrm{RC}<$ & $<180$ & & 13,90 & 20,000 & & 20,000 & 2,780 & $€ \star 100$ \\
\hline 21400 & $\mathrm{Sc}$ & jaschrt Mervobe & est & & 40,10 & 13,260 & & 13,260 & 5,317 & $€ \star 100$ \\
\hline 27210 & & nblosr RC $<160$ & 0 (RE380) & & 25,10 & 10,000 & & 10,000 & 2,510 & $€ \star 100$ \\
\hline 22100 & & ticale & & & 17,60 & 9,032 & & 9,032 & 1,590 & $€ \star 100$ \\
\hline 29810 & $\mathrm{R}$ & apschroot $\mathrm{RE}<$ & $<380$ & & 24,90 & 5,691 & & 5,691 & 1,417 & $€ \star 100$ \\
\hline 37610 & $\mathrm{Vi}$ & hasse $R E<250$ & & & 9,50 & 4,000 & & 4,000 & 0,380 & $€ \star 100$ \\
\hline 42220 & & lasse riet SUI> & 475 & & 16,50 & 3,000 & & 3,000 & 0,495 & $€ \star 100$ \\
\hline 30921 & & jasr RC50-70R & $E<450$ & & 35,30 & 1,710 & & 1,710 & 0,604 & $€ \star 100$ \\
\hline 00910 & $\mathrm{Kr}$ & jit (fijn gemalen) & & & 10,50 & 1,682 & & 1,682 & 0,177 & $€ \star 100$ \\
\hline 00913 & Zc & & & & 14,00 & 0,832 & & 0,832 & 0,116 & $€ * 100$ \\
\hline 00937 & & rvit Melkvee 31 & & & 34,00 & 0,750 & & 0,750 & 0,255 & $€ \star 100$ \\
\hline 00822 & & eum & & & 60,00 & 0,500 & & 0,500 & 0,300 & $€ \star 100$ \\
\hline 00918 & & gnesiumoxide & & & 40,00 & 0,063 & & 0,063 & 0,025 & $€^{\star} 100$ \\
\hline & & & & & 27,05 & 100,000 & & 100,000 & 27,050 & $€ \star 100$ \\
\hline Analyse & & & & & & & & & & \\
\hline Code & & nschrijving & Waarde & Eenheid & Code & Omschrijvi & & & Waarde & Eenheic \\
\hline Weende Anal & lys & & & & 114 & DVLYSh & & & 10,626 & 9 \\
\hline 1 & D & & 876,124 & g & 115 & DVMETh & & & 3,300 & g \\
\hline 111 & $\mathrm{D}$ & Sref & 876,124 & g & 27 & FOSp & & & 464,213 & g \\
\hline 200 & & $\mathrm{EWICHT}$ & 100,000 & g & 144 & FOSp-2 & & & 224,586 & g \\
\hline 112 & $\mathrm{O}$ & & 340,980 & g & 380 & Kok. s+s & & & & $\%$ \\
\hline 133 & $\mathrm{O}$ & Kh_ & 247,215 & g & 379 & Kok+Palm & & & 20,000 & $\%$ \\
\hline 2 & & & 94,591 & g & 415 & Maïsglutenv & voerP & & & $\%$ \\
\hline 5 & $\mathrm{R}$ & & 84,094 & g & & ROD & & & & \\
\hline 3 & & E_(excl_NH3) & 325,000 & g & 372 & Maisprod & & & & $\%$ \\
\hline 4 & & IET & 31,460 & g & 375 & Mel+Vin & & & 7,000 & $\%$ \\
\hline 132 & & /ETh & 17,707 & $\mathrm{~g}$ & $3 / 6.25$ & $\mathrm{~N}$ & & & 52,000 & g \\
\hline 7 & SI & & 76,498 & g & 8 & NDF & & & 220,844 & g \\
\hline 97 & & cht & 123,876 & g & 405 & OEB_1991 & & & 98,301 & g \\
\hline 95 & & Tam & 56,505 & g & 145 & OEB-2 & & & 21,366 & g \\
\hline 6 & & Tew & 60,000 & g & 29 & OEB-2007 & & & 99,498 & g \\
\hline & & & & & 414 & Olie+VetPR & OD & & & $\%$ \\
\hline Mineralen & & & & & & & & & & \\
\hline & & & & & 416 & P/RE & & & 1,834 & $\%$ \\
\hline 11 & $\mathrm{C}$ & & 10,000 & g & & & & & & \\
\hline & & & & & 408 & PalmpitPRC & & & 20,000 & $\%$ \\
\hline $11 / 12$ & & /P & 1,678 & g & & & & & & \\
\hline & & & & & 374 & Peulvr & & & & $\%$ \\
\hline 16 & $\mathrm{Cl}$ & & 6,347 & g & & & & & & \\
\hline & & & & & 378 & Pulp & & & & $\%$ \\
\hline 14 & K & & 17,581 & g & & & & & & \\
\hline & & & & & 381 & Raapprod & & & 5,691 & $\%$ \\
\hline 13 & $\mathrm{M}$ & & 6,000 & g & & & & & & \\
\hline & & & & & $3 / 1$ & RE/kg DS & & & 370,952 & g \\
\hline 15 & $\mathrm{~N}$ & & 4,000 & g & & & & & & \\
\hline & & & & & 140 & RNSP & & & 89,307 & g \\
\hline 12 & $\mathrm{P}$ & & 5,961 & g & & & & & & \\
\hline & & & & & 401 & RVET_com & pleet & & 36,307 & g \\
\hline Runderen & & & & & 370 & Su+onbZm & & & 135,328 & g \\
\hline 9 & $A D$ & & 136,996 & g & 116 & SW & & & 86,196 & $\mathrm{~kg}$ \\
\hline 10 & $A[$ & & 26,363 & g & 373 & Tarweprod & & & & $\%$ \\
\hline 382 & & stprod & 13,260 & $\%$ & 25 & VEM & & & 940,000 & $\mathrm{~kg}$ \\
\hline 130 & & ET & 5,388 & g & $25 / 1$ & VEM/DS & & & $1.072,907$ & - \\
\hline 404 & & /E_1991 & 180,000 & g & 402 & VertCOefRE & & & 79,840 & $\%$ \\
\hline 28 & & E-2007 & 176,595 & g & 400 & VREherk & & & 286,113 & g \\
\hline & & & & & & & & & & \\
\hline Methaanemis & ssi & & & & & & & & & \\
\hline 513 & & $0 \%$ snijmais & 16,998 & $\mathrm{~g} \mathrm{CH} 4 / \mathrm{kg}$ & & & & & & \\
\hline 514 & & $80 \%$ snijmais & 17,830 & $\mathrm{~g} \mathrm{CH} 4 / \mathrm{kg}$ & & & & & & \\
\hline & & & & & & & & & & \\
\hline
\end{tabular}


Bijlage 2c, Resultaat basisoptimalisatie voor zetmeelbrok (geen restrictie voor methaanemissie)

\begin{tabular}{|c|c|c|c|c|c|c|c|c|c|c|}
\hline \multicolumn{3}{|c|}{ BESTMIX TM } & & & & \multirow{4}{*}{$\begin{array}{r}\text { Versie } \\
\text { Diergroep }\end{array}$} & & \multirow{2}{*}{\multicolumn{3}{|c|}{$\begin{array}{r}\text { Kostenformulier } \\
27-05-2015-20: 31 \\
\end{array}$}} \\
\hline \multirow{3}{*}{$\begin{array}{l}\text { Product } \\
\text { Fabriek }\end{array}$} & \multirow{2}{*}{\multicolumn{2}{|c|}{$1121.71 \mathrm{~F} 4 \mathrm{~F}$}} & & & & & & & & \\
\hline & & & \multicolumn{2}{|c|}{ Zetmeelbrok 980-100--10 F4F } & & & 1 & \multicolumn{2}{|c|}{ (Productnummer } & 3369) \\
\hline & \multicolumn{2}{|c|}{ ZET } & & & & & \multicolumn{2}{|c|}{ Melkkoeien } & & \\
\hline Omschrijvin & & Matig eiwitrijk & brok $980-100--10$ & F4F - Zetmee & Ibrok & & & & & \\
\hline Prijslijst & & rundveevoeder & 201505 & & & & & & & \\
\hline Ingrediënt & & & & Prijs(€*1 & $00 / 100 \mathrm{~kg})$ & perc. & & Gewicht (kg) & Prijs & \\
\hline 11200 & $\mathrm{M}$ & ais & & & 17,45 & 30,000 & & 30,000 & 5,235 & $€ \star 100$ \\
\hline 31020 & & jahulln RC 320 & -360 & & 13,25 & 20,000 & & 20,000 & 2,650 & $€ * 100$ \\
\hline 26410 & & almpitschilf $\mathrm{RC}<$ & $<180$ & & 13,90 & 20,000 & & 20,000 & 2,780 & $€ \star 100$ \\
\hline 21200 & & rrweglutenvoer g & gedr uit NPL & & 15,60 & 10,000 & & 10,000 & 1,560 & $€ \star 100$ \\
\hline 21400 & & jaschrt Mervobe & est & & 40,10 & 5,186 & & 5,186 & 2,080 & $€ * 100$ \\
\hline 37040 & & etpulp SUI > 200 & & & 15,75 & 4,593 & & 4,593 & 0,723 & $€ \star 100$ \\
\hline 37610 & & hasse $R E<250$ & & & 9,50 & 3,760 & & 3,760 & 0,357 & $€ * 100$ \\
\hline 42220 & & elasse riet SUI> & 475 & & 16,50 & 3,000 & & 3,000 & 0,495 & $€ \star 100$ \\
\hline 00937 & & ervit Melkvee 31 & & & 34,00 & 0,750 & & 0,750 & 0,255 & $€ * 100$ \\
\hline 00910 & & ijt (fijn gemalen) & & & 10,50 & 0,711 & & 0,711 & 0,075 & $€ * 100$ \\
\hline 12510 & & aisglvoer $\mathrm{RE}<2$ & 200 & & 18,75 & 0,649 & & 0,649 & 0,122 & $€ \star 100$ \\
\hline 00822 & & eum & & & 60,00 & 0,500 & & 0,500 & 0,300 & $€ \star 100$ \\
\hline 00848 & & almolie Arkerv. & & & 61,50 & 0,438 & & 0,438 & 0,270 & $€ * 100$ \\
\hline 00913 & Zc & ut & & & 14,00 & 0,360 & & 0,360 & 0,050 & $€ * 100$ \\
\hline 00918 & & agnesiumoxide & & & 40,00 & 0,052 & & 0,052 & 0,021 & $€ * 100$ \\
\hline & & & & & 16,97 & 100,000 & & 100,000 & 16,972 & $\epsilon^{*} 100$ \\
\hline Analyse & & & & & & & & & & \\
\hline Code & & nschrijving & Waarde & Eenheid & Code & Omschrijvin & & & Waarde & Eenhei \\
\hline Weende Ana & lys & & & & 28 & DVE-2007 & & & 103,642 & g \\
\hline$\Gamma$ & $D$ & & 879,739 & g & 114 & DVLYSh & & & 5,947 & g \\
\hline 111 & & Sref & 879,739 & g & 115 & DVMETh & & & 2,228 & $\mathrm{~g}$ \\
\hline 200 & & EWICHT & 100,000 & g & 27 & FOSp & & & 448,429 & $\mathrm{~g}$ \\
\hline 112 & $\mathrm{O}$ & & 437,634 & $\mathrm{~g}$ & 144 & FOSp-2 & & & 192,911 & $\mathrm{~g}$ \\
\hline 133 & $\mathrm{O}$ & $\mathrm{Kh}_{-}$ & 309,449 & g & 380 & Kok.s+s & & & & $\%$ \\
\hline 2 & $\mathrm{R}$ & $\mathrm{AS}^{-}$ & 66,559 & g & 379 & Kok+Palm & & & 20,000 & $\%$ \\
\hline 5 & $\mathrm{R}$ & & 122,813 & g & 415 & Maïs glutenv & voerP & & 0,649 & $\%$ \\
\hline 3 & & E_(excl_NH3) & 145,000 & g & & ROD & & & & \\
\hline 4 & & VET & 39,423 & g & 372 & Maisprod & & & 30,649 & $\%$ \\
\hline 132 & & VETh & 27,086 & g & 375 & Mel+Vin & & & 6,760 & $\%$ \\
\hline 7 & $\mathrm{~S}$ & & 53,921 & g & $3 / 6.25$ & $\mathrm{~N}$ & & & 23,200 & g \\
\hline 97 & & cht & 120,261 & g & 8 & NDF & & & 300,555 & g \\
\hline 95 & & ETam & 206,406 & g & 405 & OEB_1991 & & & $-2,470$ & g \\
\hline 6 & & ETew & 222,700 & g & 145 & OEB-2 & & & $-8,982$ & g \\
\hline & & & & & 29 & OEB-2007 & & & $-8,145$ & $\mathrm{~g}$ \\
\hline Mineralen & & & & & & & & & & \\
\hline & & & & & 414 & Olie+VetPRC & OD & & 0,438 & $\%$ \\
\hline 11 & C & & 6,000 & g & & & & & & \\
\hline & & & & & 416 & P/RE & & & 2,414 & $\%$ \\
\hline $11 / 12$ & & $a / P$ & 1,714 & g & & & & & & \\
\hline & & & & & 408 & PalmpitPRO & & & 20,000 & $\%$ \\
\hline 16 & C & & 3,786 & g & & & & & & \\
\hline & & & & & 374 & Peulvr & & & & $\%$ \\
\hline 14 & $\mathrm{~K}$ & & 11,731 & g & & & & & & \\
\hline & & & & & 378 & Pulp & & & 4,593 & $\%$ \\
\hline 13 & M & & 5,000 & g & & & & & & \\
\hline & & & & & 381 & Raapprod & & & & $\%$ \\
\hline 15 & $\mathrm{~N}$ & & 2,500 & g & & & & & & \\
\hline & & & & & $3 / 1$ & RE/kg DS & & & 164,822 & g \\
\hline 12 & $\mathrm{P}$ & & 3,500 & g & & & & & & \\
\hline & & & & & 140 & RNSP & & & 80,012 & g \\
\hline Runderen & & & & & 401 & RVET_comp & pleet & & 46,008 & g \\
\hline 9 & & $\mathrm{~F}$ & 175,633 & g & 370 & Su+onbZm & & & 210,936 & g \\
\hline 10 & & $\mathrm{~L}$ & 21,623 & $\mathrm{~g}$ & 116 & SW & & & 86,273 & $\mathrm{~kg}$ \\
\hline 382 & & estprod & 5,186 & $\%$ & 373 & Tarweprod & & & 10,000 & $\%$ \\
\hline 130 & & ZET & 66,966 & g & 25 & VEM & & & 980,000 & $\mathrm{~kg}$ \\
\hline 404 & & VE_1991 & 100,000 & g & $25 / 1$ & VEM/DS & & & $1.113,966$ & - \\
\hline & & & & & & & & & & \\
\hline Methaanemis & ss & & & & & & & & & \\
\hline 513 & & $0 \%$ snijmais & 17,990 & $\mathrm{~g} \mathrm{CH} 4 / \mathrm{kg}$ & & & & & & \\
\hline 514 & & $=80 \%$ snijmais & 17,265 & $\mathrm{~g} \mathrm{CH} 4 / \mathrm{kg}$ & & & & & & \\
\hline & & & & & & & & & & \\
\hline
\end{tabular}




\section{Bijlage 3}

Bijlage 3a, Grondstoffensamenstelling (\%) optimalisaties voor productiebrok

\begin{tabular}{|c|c|c|c|c|c|}
\hline \multirow[t]{2}{*}{ Productiebrok } & \multirow[b]{2}{*}{$100 \% \mathrm{GHG}$} & \multicolumn{2}{|c|}{ EF80\% } & \multicolumn{2}{|c|}{ EF0\% } \\
\hline & & $95 \% \mathrm{GHG}$ & $90 \% \mathrm{GHG}$ & $95 \%$ GHG & $90 \%$ GHG \\
\hline & perc. & perc. & perc. & perc. & perc. \\
\hline Sojahulln RC 320-360 & 20,00 & 20,00 & 20,00 & 20,00 & 20,00 \\
\hline Palm pits chilf $\mathrm{RC}<180$ & 20,00 & 20,00 & 20,00 & 20,00 & 20,00 \\
\hline Bietpulp SUI > 200 & 17,99 & 9,02 & 2,72 & 7,98 & 0,00 \\
\hline Mais & 12,10 & 18,56 & 29,55 & 24,07 & 29,56 \\
\hline Tarweglutenvoer gedr uit NPL & 10,00 & 10,00 & 0,00 & 0,00 & 0,00 \\
\hline Sojaschrt Mervobest & 5,61 & 2,94 & 0,18 & 0,00 & 2,52 \\
\hline Zonblosr RC $<160($ RE380) & 5,39 & 5,49 & 8,19 & 7,29 & 3,22 \\
\hline Vinasse $R E<250$ & 4,00 & 4,00 & 4,00 & 4,00 & 4,00 \\
\hline Melasse riet SUI>475 & 3,00 & 3,00 & 3,00 & 3,00 & 3,00 \\
\hline Mervit Melkvee 31 & 0,75 & 0,75 & 0,75 & 0,75 & 0,75 \\
\hline Ureum & 0,50 & 0,50 & 0,50 & 0,50 & 0,50 \\
\hline Krijt (fijn gemalen) & 0,39 & 0,66 & 1,63 & 0,70 & 1,69 \\
\hline Zout & 0,27 & 0,32 & 0,63 & 0,40 & 0,84 \\
\hline Mervobest Raap & 0,00 & 4,76 & 8,86 & 8,98 & 6,63 \\
\hline Tarwegries & 0,00 & 0,00 & 0,00 & 2,35 & 0,00 \\
\hline Zonblosr RC > 240 (RE280) & 0,00 & 0,00 & 0,00 & 0,00 & 6,37 \\
\hline Palmolie Arkerv. & 0,00 & 0,00 & 0,00 & 0,00 & 0,50 \\
\hline Lijnzaad & 0,00 & 0,00 & 0,00 & 0,00 & 0,41 \\
\hline Totaal & 100,00 & 100,00 & 100,00 & 100,00 & 100,00 \\
\hline
\end{tabular}


Bijlage 3b, Grondstoffensamenstelling (\%) optimalisaties voor eiwitbrok

\begin{tabular}{|c|c|c|c|c|c|}
\hline \multirow[t]{2}{*}{ Eiwitbrok } & \multirow[b]{2}{*}{$100 \% \mathrm{GHG}$} & \multicolumn{2}{|c|}{ EF80\% } & \multicolumn{2}{|c|}{ EF0\% } \\
\hline & & $95 \%$ GHG & $90 \% \mathrm{GHG}$ & $95 \% \mathrm{GHG}$ & $90 \% \mathrm{GHG}$ \\
\hline & perc. & perc. & perc. & nerc & perc. \\
\hline Sojasr RC50-70RE>450 & 29,48 & 31,45 & 23,69 & 17,67 & 6,80 \\
\hline Palmpitschilf $\mathrm{RC}<180$ & 20,00 & 17,13 & 13,83 & 12,16 & 11,92 \\
\hline Sojaschrt Mervobest & 13,26 & 15,00 & 15,00 & 15,00 & 15,00 \\
\hline Zonblosr RC < 160 (RE380) & 10,00 & 10,00 & 10,00 & 10,00 & 10,00 \\
\hline Triticale & 9,03 & 0,00 & 0,00 & 0,00 & 0,00 \\
\hline Raapschroot RE $<380$ & 5,69 & 0,00 & 0,00 & 15,23 & 18,23 \\
\hline Vinasse $R E<250$ & 4,00 & 4,00 & 4,00 & 4,00 & 4,00 \\
\hline Melasse riet SUI>475 & 3,00 & 3,00 & 3,00 & 3,00 & 3,00 \\
\hline Sojasr RC50-70RE<450 & 1,71 & 0,00 & 0,00 & 0,00 & 0,00 \\
\hline Krijt (fijn gemalen) & 1,68 & 2,80 & 3,57 & 2,27 & 3,39 \\
\hline Zout & 0,83 & 0,83 & 1,62 & 0,83 & 1,62 \\
\hline Mervit Melkvee 31 & 0,75 & 0,75 & 0,75 & 0,75 & 0,75 \\
\hline Ureum & 0,50 & 0,50 & 0,50 & 0,50 & 0,50 \\
\hline Magnesiumoxide & 0,06 & 0,07 & 0,08 & 0,02 & 0,05 \\
\hline Mervobest Raap & 0,00 & 5,00 & 5,00 & 4,77 & 1,77 \\
\hline Mais & 0,00 & 9,04 & 7,53 & 6,93 & 4,74 \\
\hline Palmolie Arkerv. & 0,00 & 0,42 & 0,50 & 0,50 & 0,00 \\
\hline Maisglutenmeel & 0,00 & 0,00 & 4,16 & 0,00 & 5,30 \\
\hline Lijnzaad & 0,00 & 0,00 & 3,46 & 0,00 & 1,86 \\
\hline Zonblosr RC > 240 (RE280) & 0,00 & 0,00 & 3,32 & 0,00 & 1,08 \\
\hline Sojabonen verhit & 0,00 & 0,00 & 0,00 & 6,37 & 10,00 \\
\hline Totaal & 100,00 & 100,00 & 100,00 & 100,00 & 100,00 \\
\hline
\end{tabular}


Bijlage 3c, Grondstoffensamenstelling (\%) optimalisaties voor zetmeelbrok

\begin{tabular}{|c|c|c|c|c|c|}
\hline \multirow[t]{2}{*}{ Zetmeelbrok } & \multirow[b]{2}{*}{$100 \% \mathrm{GHG}$} & \multicolumn{2}{|c|}{$\mathrm{EF} 80 \%$} & \multicolumn{2}{|c|}{$\mathrm{EF} 0 \%$} \\
\hline & & $95 \% \mathrm{GHG}$ & $90 \% \mathrm{GHG}$ & $95 \%$ GHG & $90 \% \mathrm{GHG}$ \\
\hline & perc. & perc. & perc. & perc. & perc. \\
\hline Mais & 30,00 & 30,00 & 30,00 & 29,97 & 30,01 \\
\hline Sojahulln RC $320-360$ & 20,00 & 11,40 & 0,00 & 20,00 & 4,59 \\
\hline Palmpits chilf $R C<180$ & 20,00 & 20,00 & 20,00 & 20,00 & 20,00 \\
\hline Tarweglutenvoer gedr uit NPL & 10,00 & 3,08 & 0,00 & 0,00 & 0,00 \\
\hline Sojaschrt Mervobest & 5,19 & 5,50 & 4,93 & 0,43 & 0,00 \\
\hline Bietpulp SUI > 200 & 4,59 & 0,00 & 0,00 & 0,00 & 0,00 \\
\hline Vinasse $R E<250$ & 3,76 & 4,00 & 3,00 & 4,00 & 4,00 \\
\hline Melasse riet SUI>475 & 3,00 & 3,00 & 5,00 & 3,00 & 3,00 \\
\hline Mervit Melkvee 31 & 0,75 & 0,75 & 0,75 & 0,75 & 0,75 \\
\hline Krijt (fijn gemalen) & 0,71 & 1,91 & 2,08 & 1,74 & 2,00 \\
\hline Maisglvoer RE < 200 & 0,65 & 5,01 & 3,35 & 0,88 & 6,40 \\
\hline Ureum & 0,50 & 0,50 & 0,50 & 0,50 & 0,50 \\
\hline Palmolie Arkerv. & 0,44 & 0,50 & 0,50 & 0,26 & 0,00 \\
\hline Zout & 0,36 & 0,40 & 0,86 & 0,79 & 0,80 \\
\hline Magnesiumoxide & 0,05 & 0,08 & 0,53 & 0,05 & 0,44 \\
\hline Gerst & 0,00 & 13,88 & 24,54 & 0,00 & 0,00 \\
\hline Lijnzaad & 0,00 & 0,00 & 2,80 & 2,13 & 4,56 \\
\hline Maisglutenmeel & 0,00 & 0,00 & 1,17 & 0,00 & 5,36 \\
\hline Tarwe & 0,00 & 0,00 & 0,00 & 6,70 & 7,60 \\
\hline Vet/olie plant hg VC als SOJAolie & 0,00 & 0,00 & 0,00 & 0,24 & 0,00 \\
\hline Zonblosr RC > 240 (RE280) & 0,00 & 0,00 & 0,00 & 0,00 & 10,00 \\
\hline Mervobest Raap & 0,00 & 0,00 & 0,00 & 8,55 & 0,00 \\
\hline Totaal & 100,00 & 100,00 & 100,00 & 100,00 & 100,00 \\
\hline
\end{tabular}


